\title{
Financial Services FY 1995 Site Support Program Plan WBS 6.10.4
}

\author{
E. P. Vodney
}

Date Published

September 1994

Prepared for the U.S. Department of Energy

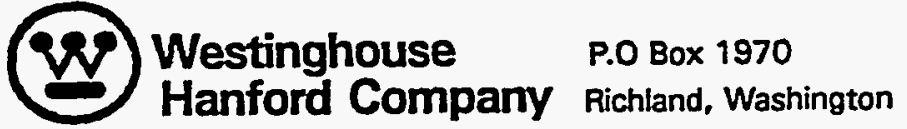

Hanford Operstions and Engineering Contractor for the U.S. Department of Energy under Contract DE-ACO6-87RL10930

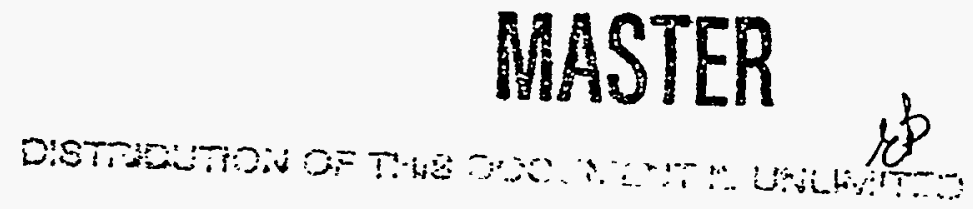

Approved for Public Release 


\section{DISCLAIMER}

This report was prepared as an account of work sponsored by an agency of the United States Government. Neither the United States Government nor any agency thereof, nor any of their employees, make any warranty, express or implied, or assumes any legal liability or responsibility for the accuracy, completeness, or usefulness of any information, apparatus, product, or process disclosed, or represents that its use would not infringe privately owned rights. Reference herein to any specific commercial product, process, or service by trade name, trademark, manufacturer, or otherwise does not necessarily constitute or imply its endorsement, recommendation, or favoring by the United States Government or any agency thereof. The views and opinions of authors expressed herein do not necessarily state or reflect those of the United States Government or any agency thereof. 


\section{DISCLAIMER}

Portions of this document may be illegible in electronic image products. Images are produced from the best available original document. 


\begin{tabular}{|c|c|}
\hline \multicolumn{2}{|r|}{ RELEASE AUTHORIZATION } \\
\hline Document Number: & WHC-SP-1106, Revision 0 \\
\hline Document Title: & $\begin{array}{l}\text { Financial Services FY } 1995 \text { Site Support Program P1an } \\
\text { WBS } 6.10 .4\end{array}$ \\
\hline Release Date: & $9 / 20 / 94$ \\
\hline \multicolumn{2}{|c|}{$\begin{array}{l}\text { This document was reviewed following the } \\
\text { procedures described in WHC-CM-3-4 and is: }\end{array}$} \\
\hline \multicolumn{2}{|r|}{ APPROVED FOR PUBLIC RELEASE } \\
\hline \multicolumn{2}{|c|}{ WHC Information Release Administration Specialist: } \\
\hline \multicolumn{2}{|r|}{ C. Willingham } \\
\hline \multicolumn{2}{|c|}{ (Signature) } \\
\hline
\end{tabular}




\section{CORRESPONDENCE DISTRIBUTION COVERSHEET}
Author
Addressee
Correspondence No.
J. E. White
N. M. Highl and, RL
$9455764 \mathrm{Rl}$

subject: FISCAL YEAR 1995 SITE SUPPORT PROGRĀM PLAN - FINANCIAL SERVICES 6.10.4

INTERNAL DISTRIBUTION

\begin{tabular}{|c|c|c|c|c|c|c|}
\hline Approval & Date & & Name & Location & w/att & Copy $\#$ \\
\hline & & & Correspondence Control & A3-01 & $x$ & 1 \\
\hline & & & President's Office & B3-01 & & \\
\hline & & & OSTI (2) & A3-36 & $x$ & 2,3 \\
\hline & & & Central Files & L8-04 & $x$ & 4 \\
\hline & & & D. L. Borders & B3-62 & & \\
\hline & & & M. J. Byrd & $\mathrm{H} 3-08$ & $x$ & 5 \\
\hline & & & J. N. DeLaHunt & G1-26 & $x$ & 6 \\
\hline & & & P. C. Felts & G1-74 & $x$ & 7 \\
\hline & & & M. A. Hinchee & $B 3-53$ & $x$ & 8 \\
\hline & & & J. E. Holmes (2) & B3-62 & $x$ & 9,10 \\
\hline & & & L. C. Hubbard & $B 4-05$ & $x$ & 11 \\
\hline & & & S. L. Koreis & GI-77 & $X$ & 12 \\
\hline & & & R. T. Marte 11 & $\mathrm{H} 3-06$ & $x$ & 13 \\
\hline & & & B. J. Miller & G1-77 & $x$ & 14 \\
\hline & & & T. W. Nilson & $\mathrm{H} 3-10$ & $x$ & 15 \\
\hline & & & L. F. Peters & B3-08 & & \\
\hline & & & L. H. Peterson & B3-53 & & \\
\hline & & & D. D. Schafer & G1-73 & $x$ & 16 \\
\hline & & & E. P. Vodney & B3-50 & & \\
\hline$x$ & & & J. E. White & $B 3-58$ & $x$ & 17 \\
\hline & & RL: & $\begin{array}{l}\text { N. M. Highland } \\
\text { J. K. Absher } \\
\text { A. N. Lake } \\
\text { F. S. Zvonar } \\
\text { D. A. O'Toole }\end{array}$ & & $\begin{array}{l}x \\
X \\
x \\
X \\
X\end{array}$ & $\begin{array}{l}18 \\
19 \\
20 \\
21 \\
22\end{array}$ \\
\hline
\end{tabular}


P.O. Box 1970 Richland, WA 99352

October 3, 1994

9455764 R1

N. M. Highl and

Acting Chief Financial officer

U.S. Department of Energy

Richland Operations office

Richland, Washington 99352

Dear Ms. Highland:

FISCAL YEAR 1995 SITE SUPPORT PROGRAM PLAN - FINANCIAL SERVICES 6.10.4

References: (1) Richland Operations Office - Site Management System, RLID 5000.1, issue date August 6, 1993.

(2) U.S. Department of Energy, Richland Operations Office Long Range Planning Process, RLID 5000.2, issue date June 2, 1994.

Attached is the signed Financial Services fiscal year (FY) 1995 Site Support Program Plan (SSPP), Work Breakdown Structure (WBS) 6.10.4, for your files.

Any modifications to this approved baseline will be made through Class I Change Controt.

If you have any questions or comments, please call J. E. White on 372-1354. Very truly yours,

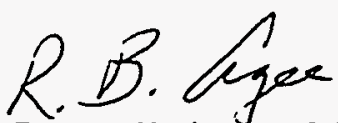

$1 \mathrm{~b}$

Attachment

RL - J.K. Absher

A. N. Lake

R. 0. Puthoff (w/o attachment)

F. S. Zvonar 


\section{FY 1995 Site Support Program Plan Approval Sheet}

\section{WBS 6.10.4 Financial Services}

Assistant Manager-Contracting Officer's Representative
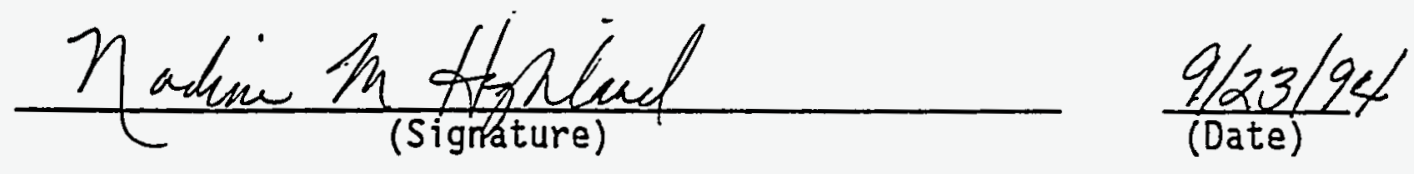

N. M. Highland

(Printed Name)

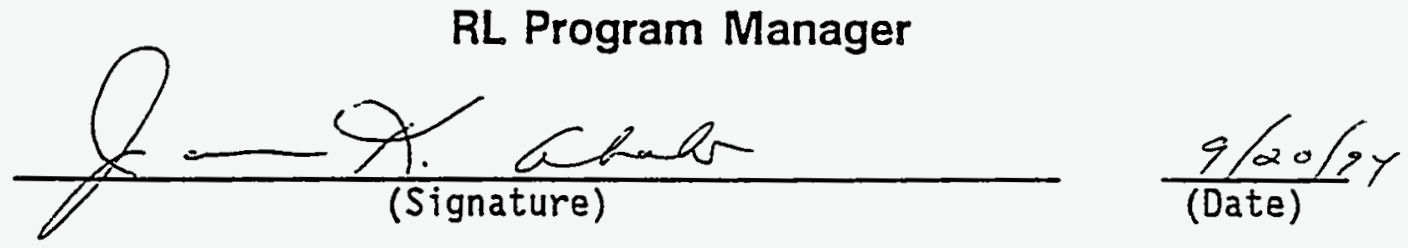

J. K. Absher

(Printed Name)
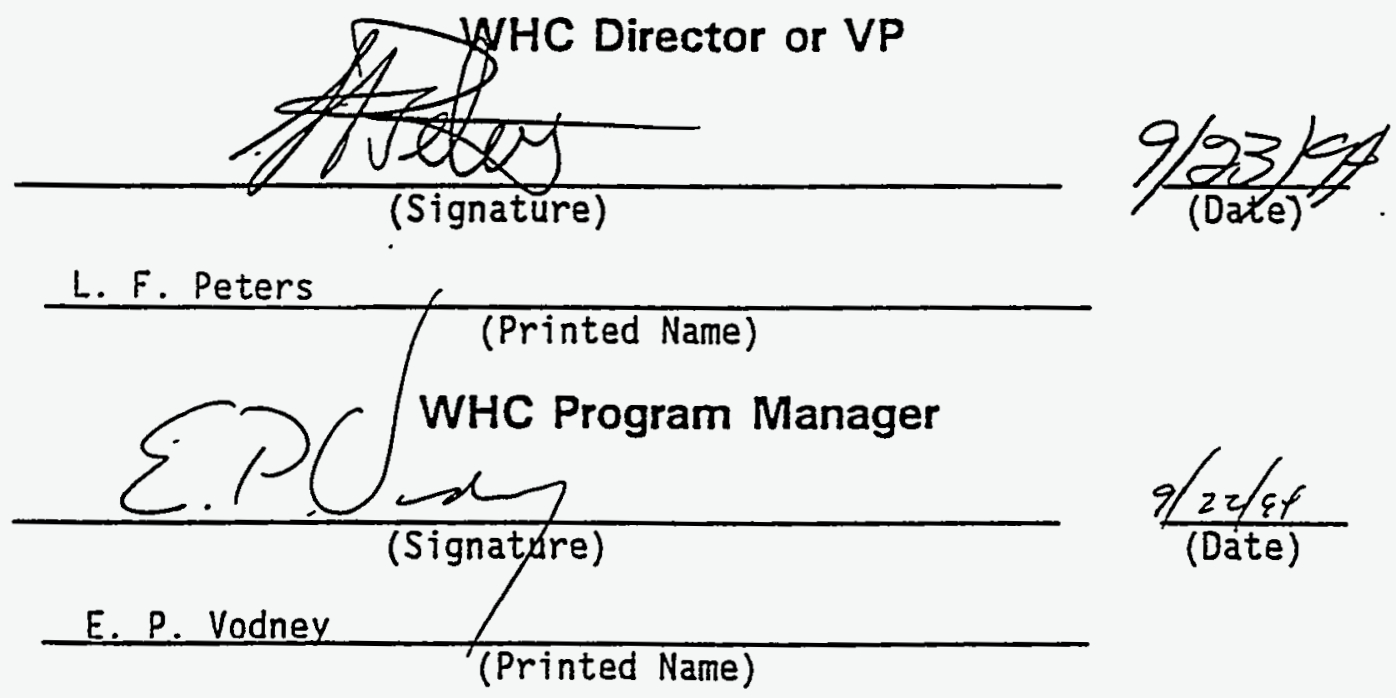
WHC-SP-1 106, Financial Services

FY 1995 Site Support Program Plan

WBS 6.10.4

Number

Title

Effective Date

1.0 Overview

1.A Vision/Mission

1.B Situational Analysis

1.B.1 Internal Assessment Summary

1.B.2

1.C

1.D

1.E

1.F

$1 . G$

External Assessment Summary

Goals and Objectives

Strategies

Assumptions

Issues and Constraints

Performance Measures

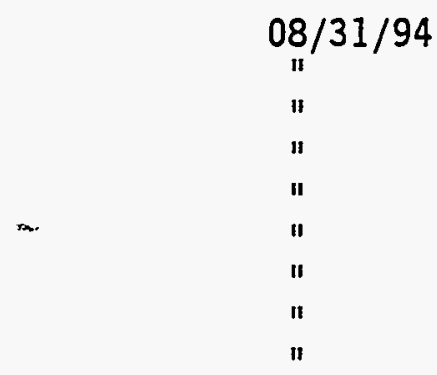

2.0

2.A

2.A.1

Baselines

Technical Baselines

Work Breakdown Structure \&

2.A.2

Responsibility Assignment Matrix

2. B

2.B. 1

Description of Activities

Schedule Baselines

2.C

Milestone List

Cost Baselines

2.C. 1

2.C.2

Cost Baseline

Cost Basis

2.C. 3

FTE Forecasts

$08 / 31 / 94$

II

II

iI

II

II

3.0 Execution Year

3.A WBS Dictionaries

3.B WBS Milestone Description Sheets

$08 / 31 / 94$ 


\begin{tabular}{|l|c|c|}
\hline $\begin{array}{c}\text { Work Breakdown } \\
\text { Structure }\end{array}$ & $\begin{array}{c}\text { Westinghouse Hanford Company } \\
\text { Finance and Administration } \\
\text { SMS/WBS No. 6.10 }\end{array}$ & $\begin{array}{c}\text { FY 1995 } \\
\text { Site Support Program Plan } \\
\text { Date Prepared: 8/31/94 }\end{array}$ \\
\hline
\end{tabular}

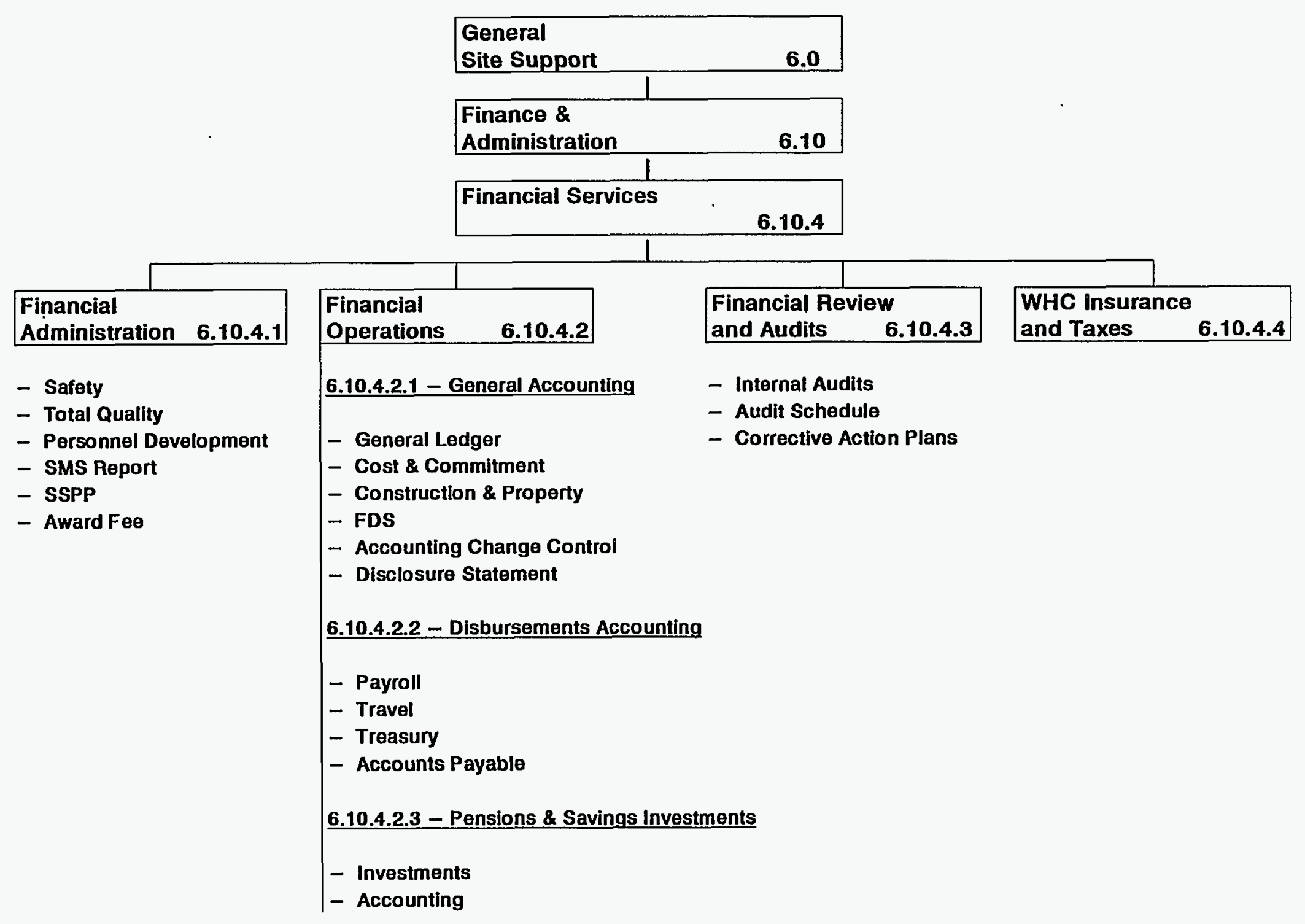




\begin{tabular}{|l|c|c|}
\hline 1.A Vision/Mission & $\begin{array}{c}\text { Westinghouse Hanford Company } \\
\text { Finance and Administration } \\
\text { SMS/WBS No.6.10 }\end{array}$ & $\begin{array}{c}\text { FY 1995 } \\
\text { Site Support Program Plan } \\
\text { Date Prepared: } 08 / 31 / 94\end{array}$ \\
\hline
\end{tabular}

\section{Financial Services \\ WBS 6.10.4}

Ensure financial integrity in all Westinghouse Hanford Company (WHC) operations while supporting the programmatic activities of WHC, the U.S. Department of Energy, Richland Operations Office (RL), and other Hanford contractors. Provide efficient and effective financial services, and value added audits and reviews that enable management to enhance future operational results. 


\begin{tabular}{|l|c|c|}
\hline & Westinghouse Hanford Company \\
Finance and Administration & FMS 1995 & $\begin{array}{c}\text { Site Support Program Plan } \\
\text { Date Prepared: } 08 / 31 / 94\end{array}$ \\
\hline
\end{tabular}

\section{Financial. Services WBS 6.10.4}

PRIMARY CUSTOMERS

- WHC/BCSR/ICF KH Cost Account Managers

- WHC/BCSR/ICF KH Financial Managers

- WHC/BCSR/ICF KH Employees

- Department of Energy (DOE) - RL Financial Management Division

- Department of Energy Inspector General (DOE-IG)

- DOE - RL/WHC Chief Financial officers

- Vendors

- Internal Revenue Service (IRS)

- Federal and State Agencies

- Westinghouse Electric Corporation (WEC) 


\begin{tabular}{|l|c|c|}
\hline 1.B.1 Internal Assessment Summary & $\begin{array}{c}\text { Westinghouse Hanford Company } \\
\text { Finance and Administration } \\
\text { SMS/WBS No. 6.10 }\end{array}$ & $\begin{array}{c}\text { FY 1995 } \\
\text { Site Support Program P1an } \\
\text { Date Prepared: } 08 / 31 / 94\end{array}$ \\
\hline
\end{tabular}

\section{Financial Services WBS 6.10 .4}

\section{PRODUCTS/SERVICES PROVIDED}

\section{- Financial Services}

- Financial Statements

- Financial System development, support, and enhancements.

- General accounting support of program operations, including maintenance of the general ledger,

construction and property (capital) accounting, and cost and commitments accounting.

- Maintenance of WHC liabilities.

- Maintenance of WHC employee pension and benefits.

- Audit reports, Management reviews, and special reviews as required.

\section{MAJOR ACTIVITIES PERFORMED TO DELIVER PRODUCTS AND SERVICES}

- Develop and implement a system of management controls that provide reasonable assurance that financial operations are efficient and effective and that incurred costs are allowable.

- Collect, allocate, and report costs.

- Maintain the integrity of WHC assets via the general ledger.

- Identify, develop, and support Financial Systems improvements. 


\begin{tabular}{|l|c|c|c|}
\hline 1.B.1 Internal Assessment Summary & $\begin{array}{c}\text { Westinghouse Hanford Company } 1995 \\
\text { Finance and Administration } \\
\text { SMS/WBS No.6.10 }\end{array}$ & $\begin{array}{c}\text { Site Support Program Plan } \\
\text { Date Prepared: } 08 / 31 / 94\end{array}$ \\
\hline
\end{tabular}

\section{Financial Services WBS 6.10.4}

\section{MAJOR ACTIVITIES PERFORMED TO DELIVER PRODUCTS AND SERVICES (continued)}

- Tracking and payment of WHC Tiabilities, e.g., Payroll, Material, Transportation, Consulting Services.

- Tracking and payment of WHC employee pension and benefits.

- Interviewing, flowcharting, analysis, sampling, testing, and report writing.

\section{EVALUATION OF MAJOR ACTIVITIES (COST, VALUE-ADDED, ETC.)}

- General Accounting compiles financial reports which provide primary customers information necessary to the management process, as well as providing a financial status of WHC operations.

- General Accounting supports the program management function by offering consultation on a variety of subjects ranging from Tax and Accounting topics to Financial Data System support.

- Disbursements Accounting provides salary preparation and payment, travel services, and accounts payable activities in support of program operations.

- Pension and benefits accounting provides coordination, fiduciary responsibility, and administration of WHC pension and benefits in support of program operations.

- Internal audit provides a contract mandated service to DOE and WHC management. The value added comes from risk abatement and efficiency changes resulting from audit recommendations. 


\begin{tabular}{|l|c|c|c|}
\hline 1.B.1 Internal Assessment Summary & $\begin{array}{c}\text { Westinghouse Hanford Company } \\
\text { Finance and Administration } \\
\text { SMS/WBS No.6.10 }\end{array}$ & $\begin{array}{c}\text { Fite Support Program P1 an } \\
\text { Date Prepared: 08/31/94 }\end{array}$ \\
\hline
\end{tabular}

\section{Financial Services \\ WBS 6.10.4}

\section{FACTORS WHICH INFLUENCE RESOURCE CONSUMPTION (CHANGES TO COST AND VOLUME)}

- General Accounting resource consumption can be affected by several factors including overall program consultation requirements, program activity level, and individual customer needs. Among these are Accounting Change Board activity, changes in tax 1aws, oversight reporting, development and implementation of new financial system enharicements, and specific customer requests.

- Audit resources are normally fixed, based upon approved staffing levels, and the approved staffing level for FY 1995 is nine employees.

- Disbursements Accounting resource consumption can be affected by program activity leve1, specific cyclical forces, and changes in the WHC scope of work.

- Pension and Benefits Accounting resource consumption can be affected by program activity level, and specific customer requests. 


\begin{tabular}{|l|c|c|}
\hline 1.B.1 Internal Assessment Summary & $\begin{array}{c}\text { Westinghouse Hanford Company } \\
\text { Finance and Administration } \\
\text { SMS/WBS No.6.10 }\end{array}$ & $\begin{array}{c}\text { FY 1995 } \\
\text { Site Support Program Plan } \\
\text { Date Prepared: 08/31/94 }\end{array}$ \\
\hline
\end{tabular}

\section{Financial Services \\ WBS 6.10.4}

\section{FACTORS THAT INFLUENCE CHANGES IN TYPES OR NATURE OF PRODUCTS AND SERVICES}

- DOE/WHC Contract No. DE-AC06-87RL-10930

- DOE Orders and Directives

- Activities must comply with current applicable codes, standards, etc.

- Federal

Internal Revenue Code Employee Retirement Income Security Act (ERISA), FIT/FICA/FUTA, Fair Labor Standards Act, Davis Bacon, Federal Travel Regulations (FTR), Federal Acquisition Regulations (FAR), DOE Acquisition Regulations (DEAR), and Federal Register.

- State

Unemployment, Wage and Hour Law, Workmen's Compensation, Garnishment, Wage Assignment, and Tax Levies

- Labor Contracts

HAMTC, Guards and Arbitration Rulings

- WEC Corporate

Controller's Manual (Policies and Procedures)

- WHC Management Guidance

Management Requirements and Procedures (MRP), Management Policies and Other Controlled Manuals. 


\begin{tabular}{|l|c|c|}
\hline 1.B.1 Internal Assessment Summary & $\begin{array}{c}\text { Westinghouse Hanford Company } \\
\text { Finance and Administration } \\
\text { SMS/WBS No.6.10 }\end{array}$ & $\begin{array}{c}\text { FY } 1995 \\
\text { Site Support Program Plan } \\
\text { Date Prepared: } 08 / 31 / 94\end{array}$ \\
\hline
\end{tabular}

\section{Financial Services \\ WBS 6.10.4}

\section{FACTORS THAT INFLUENCE CHANGES IN TYPES OR NATURE OF PRODUCTS AND SERVICES (continued)}

- Reviews that include:

- Audits which are generally planned one year in advance and proceed according to our established audit process.

- Management reviews which are generally unplanned requests from management to respond to current issues/concerns.

- Special reviews which are in response to fraud, waste, or abuse allegations received from any source. 


\begin{tabular}{|c|c|c|}
\hline 1.B.2 External Assessment Summary & $\begin{array}{c}\text { Westinghouse Hanford Company } \\
\text { Finance and Administration } \\
\text { SMS/WBS No.6.10 }\end{array}$ & $\begin{array}{c}\text { FY } 1995 \\
\text { Site Support Program P1an } \\
\text { Date Prepared: } 08 / 31 / 94\end{array}$ \\
\hline
\end{tabular}

\section{Financial Services \\ WBS 6.10.4}

\section{SUMMARY OF CUSTOMER REQUIREMENTS (NEEDS)}

- Prompt, accurate payment of liabilities.

- Accurate, timely financial information.

- Prompt, courteous response to customer requests.

- Informed, collaborative problem solving.

- An annual allowable cost audit and other audits which are conducted each fiscal year in accordance with professional audit standards as defined by the Government Accounting office. These requirements are detailed in acquisition letter 90-3R, date August 13, 1990.

- Objective assessments of the adequacy, effectiveness, and efficiency of the management controls and processes established to accomplish company objectives. 


\begin{tabular}{|c|c|c|}
\hline 1.B.2 External Assessment Summary & $\begin{array}{c}\text { Westinghouse Hanford Company } \\
\text { Finance and Administration } \\
\text { SMS/WBS No.6.10 }\end{array}$ & $\begin{array}{c}\text { FY 1995 } \\
\text { Site Support Program Plan } \\
\text { Date Prepared: 08/31/94 }\end{array}$ \\
\hline
\end{tabular}

\section{Financial Services \\ WBS 6.10.4}

\section{OTHER EXTERNAL CHALLENGES}

- Differences in the contract provisions of WHC and Bechtel Hanford, Inc. (BHI), will require 1 abor intensive collection, processing, and verification of charges flowing between the two contractors.

- The push for increased privatization and decreased staffing levels is expected to yield reviews of privatization potential and relative cost for selected Financial Services activities. 


\section{Financial Services WBS 6.10.4}

- Maintain a safe accident-free work place, conduct a11 operations in a safe manner, and instill employees with the attitude that safety is the number one priority.

- Ensure financial integrity in all WHC operations, including compliance with all applicable codes, standards, laws, and regulations.

- Provide financial support, control, and accounting processes to assure consistent and disciplined financial management of resources, programs, and organizations.

- Provide financial data, reports, and analysis of the financial status and performance of WHC programs and organizations.

- Maintain a system of financial management controls that provides reasonable assurance that financial operations are efficient and effective.

- Meet all scheduled milestones.

- Provide adequate internal control to ensure accurate, timely, and proper payment of liabilities incurred by WHC, BCSR and ICF KH.

- Provide plan administration and fund management for the pension, savings, and insurance plans as required by the Employee Retirement Income Security Act (ERISA) and other governing regulations and directives.

- $\quad$ Provide stable, cost-effective automated financial systems that meet customer requirements and are in compliance with regulatory drivers. 


\begin{tabular}{|c|c|c|}
\hline 1.C Goals and Objectives & $\begin{array}{c}\text { Westinghouse Hanford Company } \\
\text { Finance and Administration } \\
\text { SMS/WBS No.6.10 }\end{array}$ & $\begin{array}{c}\text { FY 1995 } \\
\text { Site Support Program Plan } \\
\text { Date Prepared: } 08 / 31 / 94\end{array}$ \\
\hline
\end{tabular}

\section{Financial Services WBS 6.10.4}

\section{(continued)}

- Update the integrated financial systems to satisfy changing business requirements, including programmatic requirements as well as overall WHC and RL requirements.

- Complete the ICF KH integration tasks and publish a document outlining the administration of ICF KH and WHC operations.

- $\quad$ Actively pursue electronic commerce.

- Develop and empower employees in a Total Quality culture and manage all activities in a Total Quality manner.

- Develop a baseline of performance measures that will be used to monitor performance.

- Improve productivity and reduce cost by re-engineering and/or streamlining processes.

- Provide internal audit coverage in a manner that enhances operational results, provides contract compliance, and promotes employee development. 


\begin{tabular}{|l|c|c|}
\hline 1.D Strategies & $\begin{array}{c}\text { Westinghouse Hanford Company } \\
\text { Finance and Administration } \\
\text { SMS/WBS No. } 6.10\end{array}$ & $\begin{array}{c}\text { Fite Support Program P7an } \\
\text { Date Prepared: } 08 / 31 / 94\end{array}$ \\
\hline
\end{tabular}

\section{Financial Services WBS 6.10.4}

\section{CUSTOMER SUPPORT STRATEGIES}

- Participate in Financial Management Systems Improvement Council (FMSIC) activities.

- Participate in WHC cost savings teams (e.g., G \& A Cost Reduction Team)

- Participate on cross-contractor task teams (e.g., Government Owned Contractor Operated [G0C0] contractor teams).

- Participate in monthly RL interface meetings to status problem areas and provide an update of ongoing activities.

- $\quad$ Approach problem solving in a collaborative, amicable manner. 


\begin{tabular}{|l|c|c|}
\hline & Westinghouse Hanford Company \\
Finance and Administration & FY 1995 \\
SMS/WBS No. 6.10 & $\begin{array}{c}\text { Site Support Program Plan } \\
\text { Date Prepared: } 08 / 31 / 94\end{array}$ \\
\hline
\end{tabular}

\section{Financial Services \\ WBS 6.10.4}

\section{PRODUCTION STRATEGIES}

- Provide the tools necessary to perform duties in the most efficient, effective manner possible.

- Take advantage of new technology where applicable and cost effective.

- Explore more efficient, effective alternatives to the performance of regular duties, including the consideration of privatization and outsourcing of activities.

- Continue the process of "Storyboarding" all Financial Services functions to determine process improvements that may be implemented to improve efficiency and reduce cost. 


\begin{tabular}{|l|c|c|}
\hline & Westinghouse Hanford Company \\
Finance and Administration & FY 1995 & $\begin{array}{c}\text { Site Support Program Plan } \\
\text { Date Prepared: } 08 / 31 / 94\end{array}$ \\
\hline
\end{tabular}

\section{Financial Services \\ WBS 6.10 .4}

\section{ORGANIZATION AND MANAGEMENT STRATEGIES}

- Conduct monthly safety meetings stressing pertinent safety issues.

- Encourage our personnel to participate in safety-related activities and programs.

- Ensure personnel are properly trained to perform duties.

- Ensure personnel are trained to provide adequate backup for all positions.

- Encourage ongoing training and education in areas pertinent to the performance of duties.

- Provide sufficient qualified personnel to accomplish the work scope. 


\begin{tabular}{|l|c|c|}
\hline & $\begin{array}{c}\text { Westinghouse Hanford Company } \\
\text { Finance and Administration } \\
\text { SMS/WBS No.6.10 }\end{array}$ & $\begin{array}{c}\text { Fy } \\
\text { Site Support Program Plan } \\
\text { Date Prepared: } 08 / 31 / 94\end{array}$ \\
\hline
\end{tabular}

\section{Financial Services WBS 6.10 .4}

- Support of Hanford's programmatic areas is of ultimate importance, since the programs are the funding mechanism for Hanford.

- Focus will continue on reducing the ratio of indirect costs to direct costs, particularly companylevel overhead.

- Financial Services FY 1995 staffing levels and funding will be as shown in the Execution Year Package section of this SSPP.

- RL will approve the WHC recommendations for sharing the cost of the Benefits area via the Sitewide Support pool.

- Outsourcing will continue to be available for software engineering and systems analysis support, as

- necessary, via BCSR mechanisms.

- BCSR will have Transmission Control Protocol/Internet Protocol telecommunications technology implemented as required to support applicable Financial Services projects.

- Detailed assumptions related to direct versus indirect audit days, staffing size, and risk ranking factors for the audit universe are contained in the WHC FY 1995 Audit Plan which was submitted to the DOE-IG and RL on June 30, 1994. 


\begin{tabular}{|l|c|c|}
\hline & Westinghouse Hanford Company \\
Finance and Administration & FY 1995 \\
SMS/WBS No. 6.10 & $\begin{array}{c}\text { Site Support Program Plan } \\
\text { Date Prepared: } 08 / 31 / 94\end{array}$ \\
\hline
\end{tabular}

\section{Financial Services WBS 6.10.4}

- The Financial Services staffing level was reduced, due to the creation of an Environmental Restoration Contractor (ERC), on the basis of program funding transfer to the ERC. Many activities within Financial Services are not volume-related and, consequently, reduction of work scope is likely since re-engineering and/or streamlining processes is not likely to offset the reduction to staff, especially in the near term.

- Further reduction to staff is necessary to meet revised organizational staffing ceilings driven by WHC and RL productivity goals. 


\begin{tabular}{|l|c|c|}
\hline 1.G Performance Measures & $\begin{array}{c}\text { Westinghouse Hanford Company } \\
\text { Finance and Administration } \\
\text { SMS/WBS No. 6.10 }\end{array}$ & $\begin{array}{c}\text { FY 1995 } \\
\text { Site Support Program Plan } \\
\text { Date Prepared: } 08 / 31 / 94\end{array}$ \\
\hline
\end{tabular}

\section{Financial Services \\ WBS 6.10.4}

As a result of the need for meaningful performance measures, the acknowledgement of the difference between performance measures and performance indicators, and the inherent difficulties associated with the development of the former for support organizations, i.e., predominantly level of effort services, Financial Services herein submits a partial list of performance measures, along with a corresponding milestone

(Section 2.B.1, FFS-95-015), which when completed, will provide performance measures for a larger number of Financial Services organizations. These measures include:

\section{Financial Review and Audits 6.10.4.3}

Average 17.0 Direct Audit Days per Auditor

Complete Draft Report Within Two Months of Survey Letter

Financial Expenditures Will Be Within Budget

Zero Lost Work Days in FY 1995 


\begin{tabular}{|c|c|c|c|c|c|}
\hline \multicolumn{2}{|c|}{$\begin{array}{l}\text { 2.A.1 } \\
\text { Work Breakdown Structure and } \\
\text { Responsibility Assignment Matrix }\end{array}$} & \multicolumn{2}{|c|}{$\begin{array}{c}\text { Westinghouse Hanford Company } \\
\text { Finance and Administration } \\
\text { SMS/WBS No. } 6.10 \\
\end{array}$} & \multicolumn{2}{|c|}{$\begin{array}{l}\text { FY } 1995 \\
\text { Site Support Program Plan } \\
\text { Date Prepared: } 08 / 31 / 94 \\
\end{array}$} \\
\hline $\begin{array}{l}\text { Program } \\
\text { Element }\end{array}$ & $\begin{array}{c}\text { Activity/Program } \\
\text { Sub-Element } \\
\end{array}$ & Cost Account & Title. & $\begin{array}{c}\text { Responsible } \\
\text { Manager }\end{array}$ & $\begin{array}{r}\text { Responsible } \\
\text { Organization } \\
\end{array}$ \\
\hline 6.10 & & & $\begin{array}{l}\text { Finance and } \\
\text { Administration }\end{array}$ & E. P. Vodney & $\begin{array}{l}\text { Financial } \\
\text { Administration } \\
\text { and Control }\end{array}$ \\
\hline 6.10 .4 & & & Financial Services & E. P. Vodney & $\begin{array}{l}\text { Financial } \\
\text { Administration } \\
\text { and Control }\end{array}$ \\
\hline 6.10 .4 .1 & & 1MDD15 & $\begin{array}{l}\text { Financial } \\
\text { Administration }\end{array}$ & E. P. Vodney & $\begin{array}{l}\text { Financial } \\
\text { Administration } \\
\text { and Control }\end{array}$ \\
\hline \multirow[t]{5}{*}{6.10 .4 .2} & & & $\begin{array}{l}\text { Financial } \\
\text { Operations }\end{array}$ & E. P. Vodney & $\begin{array}{l}\text { Financial } \\
\text { Administration } \\
\text { and Control }\end{array}$ \\
\hline & 6.10 .4 .2 .1 & & General Accounting & P. C. Felts & $\begin{array}{l}\text { Financial } \\
\text { Administration } \\
\text { and Control }\end{array}$ \\
\hline & $6.10 .4 .2 .1 . \mathrm{Al}$ & 1MDD15 & $\begin{array}{l}\text { General Ledger } \\
\text { Accounting }\end{array}$ & P. C. Felts & $\begin{array}{l}\text { Financial } \\
\text { Administration } \\
\text { and Control }\end{array}$ \\
\hline & $6.10 .4 .2 .1 . A 2$ & 1MDD15 & $\begin{array}{l}\text { Construction and } \\
\text { Property Acctg }\end{array}$ & P. C. Felts & $\begin{array}{l}\text { Financial } \\
\text { Administration } \\
\text { and Control }\end{array}$ \\
\hline & $6.10 .4 .2 .1 . \mathrm{A3}$ & 1MDD15 & $\begin{array}{l}\text { Cost and } \\
\text { Commitments Acctg }\end{array}$ & R. A. Pouley & $\begin{array}{l}\text { Finançial } \\
\text { Administration } \\
\text { and Control }\end{array}$ \\
\hline
\end{tabular}

Financial Services 6.10 .4 Page 2A-1 


\begin{tabular}{|c|c|c|c|c|c|}
\hline \multicolumn{2}{|c|}{$\begin{array}{l}\text { 2.A. } 1 \\
\text { Hork Breakdown Structure and } \\
\text { Responsibility Assignment Matrix }\end{array}$} & \multicolumn{2}{|c|}{$\begin{array}{c}\text { Westinghouse Hanford Company } \\
\text { Finance and Administration } \\
\text { SMS/WBS No. } 6.10 \\
\end{array}$} & \multicolumn{2}{|c|}{$\begin{array}{l}\text { FY } 1995 \\
\text { Site Support Program P1 an } \\
\text { Date Prepared: } 08 / 31 / 94 \\
\end{array}$} \\
\hline $\begin{array}{l}\text { Program } \\
\text { Element }\end{array}$ & $\begin{array}{c}\text { Activity/Program } \\
\text { Sub-Element } \\
\end{array}$ & Cost Account & Title & $\begin{array}{c}\text { Responsible } \\
\text { Manager }\end{array}$ & $\begin{array}{r}\text { Responsible } \\
\text { Organization } \\
\end{array}$ \\
\hline & $6.10 .4 .2 .1 . A 4$ & 1MDD15 & $\begin{array}{l}\text { Financial Data } \\
\text { Control \& Admin }\end{array}$ & D. R. Layfield & $\begin{array}{l}\text { Financial } \\
\text { Administration } \\
\text { and Control }\end{array}$ \\
\hline & $6.10 .4 .2 .1 . A 5$ & IMDD4K & Financial Systems & S. L. Koreis & $\begin{array}{l}\text { Financial } \\
\text { Administration } \\
\text { and Control }\end{array}$ \\
\hline & 6.10 .4 .2 .2 & & $\begin{array}{l}\text { Disbursements } \\
\text { Accounting }\end{array}$ & R. T. Marte11 & $\begin{array}{l}\text { Financial } \\
\text { Administration } \\
\text { and Control }\end{array}$ \\
\hline & $6.10 .4 .2 .2 . A 1$ & 1MDD15 & Payroll & D. M. Staudacher & $\begin{array}{l}\text { Financial } \\
\text { Administration } \\
\text { and Control }\end{array}$ \\
\hline & 6.10.4.2.2.A2 & $1 M D D 15$ & Salary Preparation & B. E. Tanner & $\begin{array}{l}\text { Financial } \\
\text { Administration } \\
\text { and Control } \\
\end{array}$ \\
\hline & 6.10.4.2.2.A3 & 1MDD4G & Payro11 System & T. W. Nilson & $\begin{array}{l}\text { Financial } \\
\text { Administration } \\
\text { and Control }\end{array}$ \\
\hline & 6.10.4.2.2.A4 & 1MDD15 & $\begin{array}{l}\text { Travel and } \\
\text { Treasury Services }\end{array}$ & W. D. Armstrong. & $\begin{array}{l}\text { Financial } \\
\text { Administration } \\
\text { and Control }\end{array}$ \\
\hline & $\begin{array}{c}\text { 6.10.4.2.2.A5 } \\
. \\
\end{array}$ & IMDD4K & Travel System & S: L. Koreis & $\begin{array}{l}\text { Financial } \\
\text { Administration } \\
\text { and Control }\end{array}$ \\
\hline
\end{tabular}

Financial Services $6.10 .4 \quad$ Page $2 \mathrm{~A}-2$ 


\begin{tabular}{|c|c|c|c|c|c|}
\hline \multicolumn{2}{|c|}{$\begin{array}{l}\text { 2.A.1 } \\
\text { Hork Breakdown Structure and } \\
\text { Responsibility Assignment Matrix }\end{array}$} & \multicolumn{2}{|c|}{$\begin{array}{c}\text { Westinghouse Hanford Company } \\
\text { Finance and Administration } \\
\text { SMS/WBS No. } 6.10 \\
\end{array}$} & \multicolumn{2}{|c|}{$\begin{array}{l}\text { FY } 1995 \\
\text { Site Support Program Plan } \\
\text { Date Prepared: } 08 / 31 / 94 \\
\end{array}$} \\
\hline \multirow[t]{7}{*}{$\begin{array}{l}\text { Program } \\
\text { Element }\end{array}$} & $\begin{array}{c}\text { Activity/Program } \\
\text { Sub-Element }\end{array}$ & Cost Account & Title & $\begin{array}{c}\text { Responsible } \\
\text { Manager }\end{array}$ & $\begin{array}{r}\text { Responsible } \\
\text { Organization } \\
\end{array}$ \\
\hline & 6.10.4.2.2.A6 & MPR funded & Accounts Payable & J. M. Shelt & $\begin{array}{l}\text { Financial } \\
\text { Administration } \\
\text { and Control }\end{array}$ \\
\hline & 6.10.4.2.2.A7 & MPR funded & $\begin{array}{l}\text { Accounts Payable } \\
\text { System }\end{array}$ & J. N. DeLaHunt & $\begin{array}{l}\text { Financial } \\
\text { Administration } \\
\text { and Control }\end{array}$ \\
\hline & 6.10 .4 .2 .3 & & $\begin{array}{l}\text { Pensions and } \\
\text { Savings } \\
\text { Investments }\end{array}$ & M. J. Byrd & $\begin{array}{l}\text { Financial } \\
\text { Administration } \\
\text { and Control }\end{array}$ \\
\hline & $6.10 .4 .2 .3 . \mathrm{Al}$ & IMDBPS & $\begin{array}{l}\text { Pensions and } \\
\text { Savings } \\
\text { Investments }\end{array}$ & M. J. Byrd & $\begin{array}{l}\text { Financial } \\
\text { Administration } \\
\text { and Control }\end{array}$ \\
\hline & $6.10 .4 .2 .3 . A 2$ & IMDBPS & Pension Accounting & F. F. Melton & $\begin{array}{l}\text { Financial } \\
\text { Administration } \\
\text { and Control } \\
\end{array}$ \\
\hline & $6.10 .4 .2 .3 . A 3$ & 1MDB4D & Benefit Systems & T. W. Nilson & $\begin{array}{l}\text { Financial } \\
\text { Administration } \\
\text { and Control }\end{array}$ \\
\hline 6.10 .4 .3 & & 1MDDIC & $\begin{array}{l}\text { Financial Review } \\
\text { and Audits }\end{array}$ & L. C. Hubbard & Internal Audit \\
\hline 6.10 .4 .4 & & 1MDD4A & $\begin{array}{l}\text { Taxes and } \\
\text { Insurance }\end{array}$ & E. P. Vodney & $\begin{array}{l}\text { Financial } \\
\text { Administration } \\
\text { and Control }\end{array}$ \\
\hline
\end{tabular}




\begin{tabular}{|c|c|}
\hline 2.A.2 Description of Activities & $\begin{array}{c}\text { Westinghouse Hanford Company } \\
\text { Finance and Administration } \\
\text { SMS/WBS No. } 6.10\end{array}$ \\
\hline ACTIVITY & DESCRIPTION \\
\hline 6.10.4.1 Financial Administration & $\begin{array}{l}\text { Provide centralized management direction, and leadership for } \\
\text { activities related to the mission and objectives of Financial } \\
\text { Administration and Control. In addition, provide management } \\
\text { support for personnel development and training, administration, } \\
\text { Total Quality, and Safety. Establish and monitor progress toward } \\
\text { the semi-annual Award Fee Self Assessment process. Monitor and } \\
\text { manage the Site Management System monthly report to ensure an } \\
\text { effective formal communication tool between customer (RL) and } \\
\text { Financial Services. Promote monthly staff safety meetings and } \\
\text { training across Financial Administration and Control. Coordinate } \\
\text { the Financial Services Site Support Program Plan. }\end{array}$ \\
\hline $\begin{array}{c}\text { 6.10.4.2.1.AI General Ledger } \\
\text { Accounting }\end{array}$ & $\begin{array}{l}\text { Establish and maintain accounting policies, procedures, and system } \\
\text { of accounts which meet the accounting and reporting requirements of } \\
\mathrm{RL} \text {, WHC, WEC, as well as state and federal taxation authorities, in } \\
\text { a manner which is consistent with Generally Accepted Accounting } \\
\text { Principles (GAAP) and Cost Accounting Standards (CAS). } \\
\text { Analyze accounting activity to identify charges unallowable under } \\
\text { the WHC/RL contract and decide the disposition; advise management } \\
\text { on reimbursement questions and maintain an accurate accounting for } \\
\text { al1 non-reimbursable charges. } \\
\text { Create and issue WHC accounts receivable billings, maintain an } \\
\text { accurate accounts receivable billing and tracking system, and } \\
\text { monitor collection efforts in compliance with WHC and RL policies } \\
\text { and practices. } \\
\text { Act as company liaison between the insurance carrier and claimants } \\
\text { for general and automobile liability claims and monitor all } \\
\text { insurance charges for accuracy; identify and correct errors. }\end{array}$ \\
\hline
\end{tabular}




\begin{tabular}{|c|l|l|}
\hline 2.A.2 Description of Activities & $\begin{array}{l}\text { Westinghouse Hanford Company } \\
\text { Finance and Administration } \\
\text { SMS/WBS No. 6.10 }\end{array}$ & $\begin{array}{c}\text { FY 1995 } \\
\text { Dite Support Program Plan } \\
\text { Drepared: }\end{array}$ \\
\hline ACTIVITY & \multicolumn{1}{|c|}{ DESCRIPTION } \\
\hline 6.10.4.2.1.A1 General Ledger \\
$\begin{array}{l}\text { Accounting } \\
\text { (continued) }\end{array}$ & $\begin{array}{l}\text { Identify and develop improvements and efficiencies in manual and } \\
\text { Automated Data Processing (ADP) systems and reports. } \\
\text { Provide consultation and analysis to WHC management on all 1ocal, } \\
\text { state, and federal tax issues. } \\
\text { Consult with internal and external auditors on financial audits } \\
\text { involving the general ledger and assist in deficiency resolution. } \\
\text { Direct monthly and fiscal year end closing financial statement } \\
\text { activities to meet RL and HQ schedules and goals. } \\
\text { Assist, guide, and coordinate the financial reporting and tax } \\
\text { aspects of major changes in the scope of WHC operations; } \\
\text { continualy analyze and design computer logic to satisfy the } \\
\text { expanded reporting requirements of these changes. } \\
\text { Monitor computer logic designed to interpret, evaluate and } \\
\text { determine the taxability of purchased services and materials to } \\
\text { ensure continued compliance with the appropriate tax code(s). }\end{array}$ \\
\hline
\end{tabular}




\begin{tabular}{|c|c|c|c|}
\hline \multicolumn{2}{|c|}{ 2.A.2 Description of Activities } & $\begin{array}{c}\text { Westinghouse Hanford Company } \\
\text { Finance and Administration } \\
\text { SMS/WBS No. } 6.10\end{array}$ & $\begin{array}{l}\text { FY } 1995 \\
\text { Site Support Program Plan } \\
\text { Date Prepared: } \quad 08 / 31 / 94\end{array}$ \\
\hline \multicolumn{2}{|r|}{ ACTIVITY } & \multicolumn{2}{|c|}{ DESCRIPTION } \\
\hline 6.10.4.2.1.A1 & $\begin{array}{l}\text { General Ledger } \\
\text { Accounting } \\
\text { (continued) }\end{array}$ & $\begin{array}{l}\text { Provide costing for accountabili } \\
\text { accounts receivable for events d } \\
\text { DOE; reimburse appropriate charg } \\
\text { events. } \\
\text { Maintain controls to assure Disc } \\
\text { accurate, and accounting changes } \\
\text { manner; comply with all CAS in e } \\
\text { applicable hereafter. . } \\
\text { Participate in the WEC "Savings } \\
\text { GOCO Financial Task Team. }\end{array}$ & $\begin{array}{l}\text { nts over } \$ 2,500 \text {; create } \\
\text { avoidable/unallowable by the } \\
\text { (s) for accountability } \\
\text { Statements are current, } \\
\text { ubmitted to RL in a timely } \\
\text { and any CAS which becomes } \\
\text { h Sharing" program via the }\end{array}$ \\
\hline $6.10 .4 .2 .1 . \mathrm{A} 2$ & $\begin{array}{l}\text { Construction and } \\
\text { Property Accounting }\end{array}$ & $\begin{array}{l}\text { Provide capital versus expense } \\
\text { authority on funding issues; per } \\
\text { external work orders and purchas } \\
\text { coded as capital. } \\
\text { Provide charging integrity analy } \\
\text { limitations, piecemealing, and a } \\
\text { Assess the accuracy and propriet } \\
\text { plant and equipment purchases. } \\
\text { Prepare accounting transactions; } \\
\text { construction projects; provide } \\
\text { meetings, and formal training cl }\end{array}$ & $\begin{array}{l}\text { nations; act as final } \\
\text { hird party review; review all } \\
\text { isitions over } \$ 5,000 \text {, and/or } \\
\text { rtinent to fund type } \\
\text { ility of cost. } \\
\text { ales and use tax on capital } \\
\text { ze closed equipment and } \\
\text { se to field through telecon, }\end{array}$ \\
\hline
\end{tabular}




\begin{tabular}{|c|l|c|}
\hline 2.A.2 Description of Activities & $\begin{array}{l}\text { Westinghouse Hanford Company } \\
\text { Finance and Administration } \\
\text { SMS/WBS No. 6.10 }\end{array}$ & $\begin{array}{c}\text { FY 1995 } \\
\text { Site Support Program P7an } \\
\text { Date Prepared: } 08 / 31 / 94\end{array}$ \\
\hline ACTIVITY & \multicolumn{1}{|c|}{ DESCRIPTION } \\
\hline $\begin{array}{l}\text { Property Accounting } \\
\text { (continued) }\end{array}$ & $\begin{array}{l}\text { Maintain the Capital funds authorized table in Financial Data } \\
\text { System (FDS); prepare general Tedger and 'feeder' systems } \\
\text { reconciliations; prepare financial reports. } \\
\text { Maintain the financial integrity of inventory balances; prepare } \\
\text { financial reports. } \\
\text { Prepare and issue the Nuclear Materials and Manufacturing } \\
\text { Statement; maintain classified transfer documents. } \\
\text { Maintain the Property Record Unit Catalog and Property Accounting } \\
\text { and Inventory manual for the Hanford Site. } \\
\text { Oversee capital report enhancements in FDS and Soft Reporting. }\end{array}$ \\
\hline
\end{tabular}




\begin{tabular}{|c|c|c|}
\hline Descri & ption of Activities & $\begin{array}{c}\text { Westinghouse Hanford Company } \\
\text { Finance and Administration } \\
\text { SMS/WBS No. } 6.10\end{array}$ \\
\hline \multicolumn{2}{|r|}{ ACTIVITY } & DESCRIPTION \\
\hline 6.10.4.2.1.A3 & $\begin{array}{l}\text { Cost and Commitments } \\
\text { Accounting }\end{array}$ & $\begin{array}{l}\text { Maintain and control system of accounts for recording and reporting } \\
\text { of costs including reconciliations, cost transfers, and ModMasts. } \\
\text { Plan and execute monthly and yearend closings to meet other Hanford } \\
\text { contractor and RL deadlines; prepare and submit monthly and fiscal } \\
\text { yearend closing financial statements to meet RL and DOE-HQ } \\
\text { schedules and goals. } \\
\text { Maintain, distribute assessments, and reconcile self-liquidating } \\
\text { pools. } \\
\text { Maintain and control Special Requests including RL, other DOE, } \\
\text { other Federal, other Westinghouse, and commercial. } \\
\text { Maintain a mechanism by which to report undistributed costs to } \\
\text { responsible program managers. } \\
\text { Review purchase requisitions, Requests for Proposal, external work } \\
\text { orders, and other source documents for accuracy, allowability, and } \\
\text { required information and signatures. } \\
\text { Oversee expense, report enhancements in FDS and Soft Reporting. }\end{array}$ \\
\hline
\end{tabular}




\begin{tabular}{|c|l|l|}
\hline 2.A.2 Description of Activities & $\begin{array}{l}\text { Westinghouse Hanford Company } \\
\text { Finance and Administration } \\
\text { SMS/WBS No.6.10 }\end{array}$ & $\begin{array}{c}\text { FY } 1995 \\
\text { Site Support Program PIan } \\
\text { Date Prepared: }\end{array}$ \\
\hline ACTIVITY & \multicolumn{1}{|c|}{ DESCRIPTION } \\
\hline 6.10.4.2.1.A4 Financial Data \\
$\begin{array}{l}\text { Control \& } \\
\text { Administration }\end{array}$ & $\begin{array}{l}\text { Provide orderly and timely monthly processing of the FDS to provide } \\
\text { managers and support personnel with accurate data. } \\
\text { Develop standard labor rates, escalation study, and company } \\
\text { realization hours to ensure consistent company wide application of } \\
\text { planning and costing rates. } \\
\text { Provide guidance to financial personnel through monthiy FDS } \\
\text { training classes, the Fiscal Year Budget Guideline Handbook, and } \\
\text { the Fiscal Year Startup Workshop. } \\
\text { Maintain and control FDS tables, including SMS/WBS, organization, } \\
\text { work order, precode, special activity, other feeder system, capital } \\
\text { funding, etc. } \\
\text { Oversee general ledger, capital, expense, and performance } \\
\text { measurement report enhancements and refinements in FDS and Soft } \\
\text { Reporting to ensure proper recording of financial transactions as } \\
\text { well as efficient site wide financial reporting. } \\
\text { Administer the capital multi-year files for all company programs. }\end{array}$ \\
$\begin{array}{l}\text { Provide systems support to site personnel by acting as System } \\
\text { Administrator, scheduling/planning/budget support interface, } \\
\text { preparing ad-hoc reports, and fielding telephoned requests. }\end{array}$
\end{tabular}




\begin{tabular}{|c|c|c|}
\hline 2.A.2 Description of Activities & $\begin{array}{c}\text { Westinghouse Hanford Company } \\
\text { Finance and Administration } \\
\text { SMS/WBS No. } 6.10\end{array}$ & $\begin{array}{l}\text { FY } 1995 \\
\text { Site Support Program Plan } \\
\text { Date Prepared: } 08 / 31 / 94\end{array}$ \\
\hline ACTIVITY & \multicolumn{2}{|c|}{ DESCRIPTION } \\
\hline 6.10.4.2.1.A5 Financial Systems & \multicolumn{2}{|c|}{$\begin{array}{l}\text { Develop, operate, maintain, and enhance the automated systems that } \\
\text { support the General Accounting program sub-element, Activities } \\
\text { include: developing strategic computer resource pians; preparing } \\
\text { system requirement specifications (including logical design); } \\
\text { preparing and executing test plans; preparing or assisting with } \\
\text { system manuals and related procedures; identifying opportunities } \\
\text { for improving customer productivity, system performance, and system } \\
\text { cost; physical design and programming (done by supplier personnel); } \\
\text { establishing and maintaining effective data management; integrating } \\
\text { administrative and automated processes; providing automatic data } \\
\text { processing guidance, consultation, and assistance; and solving } \\
\text { systems problems. }\end{array}$} \\
\hline 6.10.4.2.2.Al Payroll & \multicolumn{2}{|c|}{$\begin{array}{l}\text { Establish, implement and maintain payroll accounting policies, } \\
\text { procedures and requirements to comply with DOE, contract, benefit } \\
\text { plan contracts, union agreements, State and Federal regulations and } \\
\text { Corporate objectives. } \\
\text { Provide interface with outside contacts on payroll matters that } \\
\text { concern taxes, Tegal issues audits, court actions, collection } \\
\text { agencies, State and local municipal items, banks, law enforcement } \\
\text { agencies, DOE contractors, and other WHC locations. }\end{array}$} \\
\hline
\end{tabular}




\begin{tabular}{|c|c|c|}
\hline \multicolumn{2}{|c|}{ 2.A.2 Description of Activities } & $\begin{array}{l}\text { Westinghouse Hanford Company } \\
\text { Finance and Administration } \\
\text { SMS/WBS No. } 6.10\end{array}$ \\
\hline \multicolumn{2}{|r|}{ ACTIVITY } & DESCRIPTION \\
\hline $6.10 .4 .2 .2 . A 2$ & Salary Preparation & $\begin{array}{l}\text { Ensure proper approval and control of payroll payments, preparation } \\
\text { of payroll checks, maintenance of supporting pay registers, payroll } \\
\text { and contract check signing functions and distribution of payroll } \\
\text { checks. } \\
\text { Maintain the official company record of each employee's pay record, } \\
\text { absence history, and benefit plan participation. Ensure that tax } \\
\text { payments are filed and paid in accordance with State and Federal } \\
\text { regulations. }\end{array}$ \\
\hline 6.10.4.2.2.A3 & Payroll System & $\begin{array}{l}\text { Operate, maintain, and enhance the payroll system. Activities } \\
\text { included are the same as those listed for } 6.10 .4 .2 .1 \text {.A5, Financial } \\
\text { Systems. }\end{array}$ \\
\hline $6.10 .4 .2 .2 . A 4$ & $\begin{array}{l}\text { Travel and Treasury } \\
\text { Services }\end{array}$ & $\begin{array}{l}\text { Ensure compliance with applicable regulations as they relate to } \\
\text { advances, reimbursements, and expenses in the areas of business } \\
\text { travel, meetings, relocation, temporary assignments, interviews, } \\
\text { noncontract activities. } \\
\text { Audit business travel, relocation, interviewee, temporary } \\
\text { assignment expense reports, and supporting documents for contract } \\
\text { allowability and company policy. Reconcile and follow up on } \\
\text { employee receivables. } \\
\text { Responsible for cash and banking activities performed by personnel } \\
\text { who have the authority to prepare checks, receive cash, prepare } \\
\text { cash receipts, prepare bank deposits, issue bus passes, and audit } \\
\text { checks to corresponding invoices. In addition, reconcile the } \\
\text { Contract and Payroll bank accounts to the General Ledger. }\end{array}$ \\
\hline
\end{tabular}

Financial Services 6.10 .4

Page 2A-11 


\begin{tabular}{|c|c|c|c|}
\hline \multicolumn{2}{|c|}{ 2.A.2 Description of Activities } & $\begin{array}{c}\text { Westinghouse Hanford Company } \\
\text { Finance and Administration } \\
\text { SMS/WBS No. } 6.10\end{array}$ & $\begin{array}{l}\text { FY } 1995 \\
\text { Site Support Program P1an } \\
\text { Date Prepared: } 08 / 31 / 94\end{array}$ \\
\hline \multicolumn{2}{|r|}{ ACTIVITY } & \multicolumn{2}{|c|}{ DESCRIPTION } \\
\hline 6.10.4.2.2.A5 & Travel System & $\begin{array}{l}\text { Operate, maintain, and enhance } t \\
\text { included are the same as those } 1 \\
\text { Systems. }\end{array}$ & $\begin{array}{l}\text { vel system. Activities } \\
\text { for } 6.10 .4 .2 .1 . A 5 \text {, Financial }\end{array}$ \\
\hline 6.10.4.2.2.A6 & Accounts Payable & $\begin{array}{l}\text { Develop, implement and maintain } \\
\text { track and report obligations pro } \\
\text { other automated and manual syste } \\
\text { materials, cost, property and ge } \\
\text { Establish and maintain strong in } \\
\text { and accurate payment and costing } \\
\text { contract and carrier financial o }\end{array}$ & $\begin{array}{l}\text { em to accurately record, } \\
\text { interface with numerous } \\
\text { cluding purchasing, } \\
\text { ledger. } \\
\text { controls to ensure proper } \\
\text { material, services, } \\
\text { ions. }\end{array}$ \\
\hline 6.10.4.2.2.A7 & $\begin{array}{l}\text { Accounts Payable } \\
\text { System }\end{array}$ & $\begin{array}{l}\text { Operate, maintain, and enhance } t \\
\text { Activities included are the same } \\
\text { Financial Systems. }\end{array}$ & $\begin{array}{l}\text { ounts payable system. } \\
\text { ose listed for } 6.10 .4 .2 .1 . A 5 \text {, }\end{array}$ \\
\hline 6.10.4.2.3.A1 & $\begin{array}{l}\text { Pensions and } \\
\text { Savings Investments }\end{array}$ & $\begin{array}{l}\text { Instruct Trustee how to allocate } \\
\text { engagement and services of all p } \\
\text { managers, trustee, custodian, at } \\
\text { Propose plan modifications and a } \\
\text { to ensure compliance with Labor } \\
\text { savings plan regulations. Perfo } \\
\text { regulatory compliance, investmen } \\
\text { auditing. Administer company's } \\
\text { and manual records, comply with } \\
\text { negotiating premium rates and pr } \\
\text { requirements, record keep, issue } \\
\text { sitewide savings system monthly. }\end{array}$ & $\begin{array}{l}\text { s, negotiate the terms of } \\
\text { oviders to include investment } \\
\text {, accountant and actuary. } \\
\text { nts and rules and processes } \\
\text { pplicable to pension and } \\
\text { ount reconciliations, } \\
\text { gement and consultant } \\
\text { insurance plans, maintain ADP } \\
\text { tory requirements, assist in } \\
\text { es. Administer the ERISA } \\
\text { eriy statements, process }\end{array}$ \\
\hline
\end{tabular}

Financial Services 6.10 .4 


\begin{tabular}{|c|c|}
\hline 2.A.2 Description of Activities & $\begin{array}{l}\text { Westinghouse Hanford Company } \\
\text { Finance and Administration } \\
\text { SMS/WBS No. } 6.10\end{array}$ \\
\hline ACTIVITY & DESCRIPTION \\
\hline 6.10.4.2.3.A2 Pension Accounting & $\begin{array}{l}\text { Administer the ERISA requirements, record keep, assure retiree } \\
\text { payments, prepare retirement calculations, maintain Automated } \\
\text { Retiree Information System. Provide financial liaison for } \\
\text { Financial Administration and Control/Human Resources on employee } \\
\text { benefit programs. }\end{array}$ \\
\hline 6.10.4.2.3.A3 Benefit Systems & $\begin{array}{l}\text { Develop, operate, maintain, and enhance the automated systems that } \\
\text { support the Pensions and Savings Investments program sub-element. } \\
\text { Activities included are the same as those } 1 \text { isted for } 6.10 .4 .2 .1 . \text { A5, } \\
\text { Financial systems. }\end{array}$ \\
\hline $\begin{array}{l}\text { 6.10.4.3 Financial Review and } \\
\text { Audits }\end{array}$ & $\begin{array}{l}\text { Develop and administer annual internal audit plans to identify } \\
\text { internal control issues and comply with DOE directives and } \\
\text { contract. Support other agencies audit requests and coordinate } \\
\text { external audits as appropriate. }\end{array}$ \\
\hline 6.10.4.4 WHC Taxes and Insurance & $\begin{array}{l}\text { This WBS accumulates cost as required by state statutes and } \\
\text { requirements as defined in the state tax code and the Department of } \\
\text { Revenue. }\end{array}$ \\
\hline
\end{tabular}




\begin{tabular}{|c|c|c|c|c|c|}
\hline 2.B. 1 & tone List & & $\begin{array}{c}\text { Westinghouse Hanford Company } \\
\text { Finance and Administration } \\
\text { SMS/WBS No. } 6.10\end{array}$ & \multicolumn{2}{|c|}{$\begin{array}{l}\text { FY } 1995 \\
\text { Site Support Program Plan } \\
\text { Date Prepared: } 08 / 31 / 94 \\
\end{array}$} \\
\hline \multicolumn{2}{|c|}{ Milestone } & \multirow{2}{*}{$\begin{array}{l}\text { WBS } \\
\text { Number }\end{array}$} & \multirow{2}{*}{\multicolumn{2}{|c|}{ Milestone Description }} & \multirow{2}{*}{$\begin{array}{c}\text { Due } \\
\text { Date }\end{array}$} \\
\hline Type & Number & & & & \\
\hline RL & $\begin{array}{l}\text { FFS-95-001 } \\
\text { FFS-95-002 } \\
\text { FFS- } 95-003 \\
\text { FFS-95-004 } \\
\text { FFS-95-005 } \\
\text { FFS-95-006 } \\
\text { FFS-95-007 } \\
\text { FFS-95-008 } \\
\text { FFS-95-009 } \\
\text { FFS-95-010 } \\
\text { FFS- } 95-011 \\
\text { FFS } 95-012 \\
\end{array}$ & 6.10 .4 .1 & $\begin{array}{l}\text { Deliver monthly status to RL } \\
\text { Services cost savings initiat }\end{array}$ & ding Financial & $\begin{array}{l}10 / 94 \\
11 / 94 \\
12 / 94 \\
01 / 95 \\
02 / 95 \\
03 / 95 \\
04 / 95 \\
05 / 95 \\
06 / 95 \\
07 / 95 \\
08 / 95 \\
09 / 95\end{array}$ \\
\hline RL & $\begin{array}{l}\text { FFS-95-013 } \\
\text { FFS-95-014 }\end{array}$ & 6.10 .4 .1 & $\begin{array}{l}\text { Provide a Performance Self-Ev } \\
\text { describes Financial Administr } \\
\text { performance based on the prev }\end{array}$ & $\begin{array}{l}\text { ion that } \\
\text { and Control's } \\
\text { six-month period. }\end{array}$ & $\begin{array}{l}10 / 05 / 94 \\
04 / 06 / 95\end{array}$ \\
\hline RL & FFS-95-015 & 6.10 .4 .1 & $\begin{array}{l}\text { Submit report identifying per } \\
\text { Financial Services. }\end{array}$ & ance measures for & $12 / 30 / 94$ \\
\hline CNTR & FFS-95-016 & 6.10 .4 .1 & $\begin{array}{l}\text { Produce a Financial Administr } \\
\text { Total Quality Plan for calend }\end{array}$ & $\begin{array}{l}\text { and Control } \\
\text { ear } 1995 .\end{array}$ & $02 / 28 / 95$ \\
\hline RL & FFS-95-017 & 6.10 .4 .1 & $\begin{array}{l}\text { Develop a Financial Services } \\
\text { Plan for FY } 1996 \text { which will b } \\
\text { authorization of work, baseli } \\
\text { performance throughout the ye }\end{array}$ & $\begin{array}{l}\text { Support Program } \\
\text { basis for } \\
\text { anagement and }\end{array}$ & $08 / 31 / 95$ \\
\hline
\end{tabular}

Financial Services 6.10 .4 


\begin{tabular}{|c|c|c|c|c|c|}
\hline 2.B.1 & stone List & & $\begin{array}{c}\text { Westinghouse Hanford Company } \\
\text { Finance and Administration } \\
\text { SMS/WBS No. } 6.10\end{array}$ & \multicolumn{2}{|c|}{$\begin{array}{l}\text { FY } 1995 \\
\text { Site Support Program Plan } \\
\text { Date Prepared: } 08 / 31 / 94 \\
\end{array}$} \\
\hline \multicolumn{2}{|c|}{ Milestone } & \multirow{2}{*}{$\begin{array}{l}\text { WBS } \\
\text { Number }\end{array}$} & \multirow{2}{*}{\multicolumn{2}{|c|}{ Milestone Description }} & \multirow{2}{*}{$\begin{array}{l}\text { Due } \\
\text { Date }\end{array}$} \\
\hline Type & Number & & & & \\
\hline DOE-HQ & $\begin{array}{l}\text { FFS }-95-018 \\
\text { FFS- } 95-019 \\
\text { FFS }-95-020 \\
\text { FFS }-95-021 \\
\text { FFS }-95-022 \\
\text { FFS- } 95-023 \\
\text { FFS }-95-024 \\
\text { FFS }-95-025 \\
\text { FFS }-95-026 \\
\text { FFS-95-027 } \\
\text { FFS }-95-028 \\
\text { FFS }-95-029\end{array}$ & 6.10 .4 .2 & $\begin{array}{l}\text { Departmental Integrated Stand } \\
\text { Accounting System (DISCAS) an } \\
\text { Information System (FIS) }\end{array}$ & $\begin{array}{l}\text { zed Core } \\
\text { nancial }\end{array}$ & $\begin{array}{l}10 / 94 \\
11 / 94 \\
12 / 94 \\
01 / 95 \\
02 / 95 \\
03 / 95 \\
04 / 95 \\
05 / 95 \\
06 / 95 \\
07 / 95 \\
08 / 95 \\
09 / 95 \\
\end{array}$ \\
\hline DOE-HQ & FFS-95-030 & 6.10 .4 .2 & Financial Statement & & $11 / 94$ \\
\hline $\mathrm{RL}$ & FFS-95-031 & 6.10 .4 .2 & Voucher for Net Expenditures & ued (VANEA) & $11 / 94$ \\
\hline RL & FFS-95-032 & 6.10 .4 .2 & $\begin{array}{l}\text { Financial Systems Integration } \\
\text { on the current integration of } \\
\text { financial data, and activitie } \\
\text { improve that integration plus } \\
\text { technology advancements. }\end{array}$ & $\begin{array}{l}\text { efing - Brief } \mathrm{RL} \\
\text { tems containing } \\
\text { progress to } \\
\text { orporate }\end{array}$ & $11 / 01 / 94$ \\
\hline CNTR & FFS-95-033 & 6.10 .4 .2 & $\begin{array}{l}\text { Complete the installation and } \\
\text { of Imaging Software for the } A \\
\text { System. }\end{array}$ & $\begin{array}{l}\text { rational startup } \\
\text { ats Payable }\end{array}$ & $11 / 01 / 94$ \\
\hline
\end{tabular}

Financial Services 6.10 .4 


\begin{tabular}{|c|c|c|c|c|}
\hline \multicolumn{3}{|c|}{ 2.B.1 Milestone List } & $\begin{array}{l}\text { Westinghouse Hanford Company } \\
\text { Finance and Administration } \\
\text { SMS/WBS No.6.10 }\end{array}$ & $\begin{array}{l}\text { FY } 1995 \\
\text { Site Support Program Plan } \\
\text { Date Prepared: } 08 / 31 / 94 \\
\end{array}$ \\
\hline \multicolumn{2}{|c|}{ Milestone } & \multirow{2}{*}{$\begin{array}{c}\text { WBS } \\
\text { Number }\end{array}$} & \multirow[b]{2}{*}{ Milestone Description } & \multirow{2}{*}{$\begin{array}{l}\text { Due } \\
\text { Date }\end{array}$} \\
\hline Type & Number & & & \\
\hline CNTR & FFS-95-034 & 6.10 .4 .2 & $\begin{array}{l}\text { Multiple Performing Organizations - Reflect, in the } \\
\text { financial system's performance reports, the } \\
\text { capability of having multiple performing organi- } \\
\text { zations per task package. }\end{array}$ & $\begin{array}{l}11 / 05 / 94 \\
\text { (i.e., } \\
\text { October } \\
\text { month-end } \\
\text { reports) }\end{array}$ \\
\hline RL & FFS-95-035 & 6.10 .4 .2 & $\begin{array}{l}\text { Financial systems Integration - Complete the } \\
\text { integration of the ICF KH and WHC/BCSR financial } \\
\text { systems ( } i . e . \text {, the last of the business systems to } \\
\text { be integrated). }\end{array}$ & $\begin{array}{l}11 / 05 / 94 \\
\text { (i.e. } \\
\text { October } \\
\text { month-end } \\
\text { reports) }\end{array}$ \\
\hline CNTR & FFS-95-036 & 6.10 .4 .2 & $\begin{array}{l}\text { Implement Electronic Funds Transfer (EFT) } \\
\text { capability for vendor payments }\end{array}$ & $12 / 01 / 94$ \\
\hline RL & FFS-95-037 & 6.10 .4 .2 & $\begin{array}{l}\text { Submit updated report pertaining to the effects of } \\
\text { the Bechtel Hanford, Inc., transition as well as } \\
\text { downsizing as a result of other factors. }\end{array}$ & $12 / 15 / 94$ \\
\hline RL & FFS-95-038 & 6.10 .4 .2 & $\begin{array}{l}\text { Financial Business Requirements Plan - Prepare a } \\
\text { plan for determining the changing business } \\
\text { requirements that need to be met by the financial } \\
\text { system(s), including programmatic requirements as } \\
\text { well as overall WHC and RL requirements. }\end{array}$ & $12 / 15 / 94$ \\
\hline CNTR & FFS-95-039 & 6.10 .4 .2 & $\begin{array}{l}\text { Time Information System First Release - Implement } \\
\text { the first functional release of the Time } \\
\text { Information System (TIS). }\end{array}$ & $12 / 31 / 94$ \\
\hline
\end{tabular}




\begin{tabular}{|c|c|c|c|c|}
\hline \multicolumn{3}{|c|}{ 2.B.1 Milestone List } & \multicolumn{2}{|c|}{$\begin{array}{l}\text { FY } 1995 \\
\text { Site Support Program Plan } \\
\text { Date Prepared: } 08 / 31 / 94 \\
\end{array}$} \\
\hline \multicolumn{2}{|c|}{ Milestone } & \multirow{2}{*}{$\begin{array}{l}\text { WBS } \\
\text { Number }\end{array}$} & \multirow[b]{2}{*}{ Milestone Description } & \multirow{2}{*}{$\begin{array}{l}\text { Due } \\
\text { Date }\end{array}$} \\
\hline Type & Number & & & \\
\hline RL & FFS-95-040 & 6.10 .4 .2 & $\begin{array}{l}\text { Cost Accounting Standards Board Disclosure } \\
\text { Statement. }\end{array}$ & $01 / 02 / 95$ \\
\hline 'CNTR & FFS-95-041 & 6.10 .4 .2 & $\begin{array}{l}\text { Implement Operations Travel System Gateway use by a } \\
\text { smal1 number of high volume users. }\end{array}$ & $02 / 01 / 95$ \\
\hline DOE-HQ & FFS-95-042 & 6.10 .4 .2 & $\begin{array}{l}\text { Management Analysis and Reporting Systems - } \\
\text { Standard General Ledger (MARS-SGL) }\end{array}$ & $02 / 95$ \\
\hline CNTR & FFS $-95-043$ & 6.10 .4 .2 & $\begin{array}{l}\text { Complete the installation and startup of Scannable } \\
\text { Time Sheets for Exempt Payrol1, Savings Bond and } \\
\text { United Way campaigns. }\end{array}$ & $03 / 31 / 95$ \\
\hline RL & FFS-95-044 & 6.10 .4 .2 & $\begin{array}{l}\text { Financial Management System Input - Submit input } \\
\text { of financial management system information for the } \\
\text { Chief Financial Officer's five-year plan, per } \\
\text { instructions in annual DOE call letter. } \\
\quad \text {. }\end{array}$ & $\begin{array}{l}\text { Per RL } \\
\text { schedule } \\
\text { (was } \\
04 / 04 / 94 \\
\text { in prior } \\
\text { year) }\end{array}$ \\
\hline CNTR & FFS-95-045 & 6.10 .4 .2 & Property Record Unit Catalog & $06 / 15 / 95$ \\
\hline CNTR & FFS-95-046 & 6.10 .4 .2 & $\begin{array}{l}\text { Closing and Startup Schedule for FY } 1995 \text { and } \\
\text { FY } 1996\end{array}$ & $07 / 14 / 95$ \\
\hline CNTR & FFS-95-047 & 6.10 .4 .2 & $\begin{array}{l}\text { Implement, an automated interface between the } \\
\text { freight billing system and the accounts payable } \\
\text { system. }\end{array}$ & $07 / 31 / 95$ \\
\hline
\end{tabular}




\begin{tabular}{|c|c|c|c|c|}
\hline \multicolumn{3}{|c|}{ 2.B.1 Milestone List } & $\begin{array}{l}\text { Westinghouse Hanford Company } \\
\text { Finance and Administration } \\
\text { SMS/WBS No. } 6.10\end{array}$ & $\begin{array}{l}\text { FY } 1995 \\
\text { Site Support Program Plan } \\
\text { Date Prepared: } 08 / 31 / 94 \\
\end{array}$ \\
\hline \multicolumn{2}{|c|}{ Milestone } & \multirow{2}{*}{$\begin{array}{l}\text { WBS } \\
\text { Number }\end{array}$} & \multirow[b]{2}{*}{ Milestone Description } & \multirow{2}{*}{$\begin{array}{l}\text { Due } \\
\text { Date }\end{array}$} \\
\hline Type & Number & & & \\
\hline CNTR & FFS-95-048 & 6.10 .4 .2 & $\begin{array}{l}\text { Kaiser Project Control Number Enhancement - Expand } \\
\text { the financial system's purge process and modify } \\
\text { master (MODMAST) process to include Kaiser Project } \\
\text { Control Numbers (KPCNS). }\end{array}$ & $08 / 01 / 95$ \\
\hline CNTR & FFS-95-049 & 6.10 .4 .2 & $\begin{array}{l}\text { Time Information System Full Implementation - Time } \\
\text { Information System implemented for all WHC/ } \\
\text { ICF KH/BCSR organizations. }\end{array}$ & $09 / 30 / 95$ \\
\hline RL & FFS-95-050 & 6.10 .4 .2 & $\begin{array}{l}\text { Identify and implement business changes to provide } \\
\text { Electronic Data Interchange capabilities within the } \\
\text { Accounts Payable System. }\end{array}$ & $09 / 30 / 95$ \\
\hline RL & $\begin{array}{l}\text { FFS }-95-051 \\
\text { FFS }-95-052 \\
\text { FFS }-95-053 \\
\text { FFS }-95-054 \\
\end{array}$ & 6.10 .4 .3 & Quarterly DARTS and status reports & $\begin{array}{l}10 \text { working } \\
\text { days after } \\
\text { end of } \\
\text { each qtr }\end{array}$ \\
\hline CNTR & $\begin{array}{l}\text { FFS }-95-055 \\
\text { FFS }-95-056 \\
\text { FFS-95-057 } \\
\text { FFS-95-058 }\end{array}$ & 6.10 .4 .3 & Corrective Action Follow-up & $\begin{array}{l}\text { end of } \\
\text { each } \\
\text { fiscal } \\
\text { quarter }\end{array}$ \\
\hline RL & FFS-95-059 & 6.10 .4 .3 & Annual Allowable Cost Audit & $12 / 30 / 94$ \\
\hline CNTR & FFS-95-060 & 6.10 .4 .3 & $\begin{array}{l}\text { Electronic Auditing - Initiate and complete a study } \\
\text { of electronic audit process software packages in } \\
\text { conjunction with Westinghouse Electric Corporate } \\
\text { Audit. }\end{array}$ & $12 / 31 / 94$ \\
\hline RL & FFS $-95-061$ & 6.10 .4 .3 & Annual IG Summary Report & $01 / 15 / 95$ \\
\hline
\end{tabular}

Financial Services 6.10 .4 


\begin{tabular}{|c|c|c|c|c|c|}
\hline \multicolumn{3}{|c|}{ 2.B.1 Milestone List } & $\begin{array}{c}\text { Westinghouse Hanford Company } \\
\text { Finance and Administration } \\
\text { SMS/WBS No.6.10 }\end{array}$ & \multicolumn{2}{|c|}{$\begin{array}{l}\text { FY } 1995 \\
\text { Site Support Program P1 an } \\
\text { Date Prepared: } 08 / 31 / 94\end{array}$} \\
\hline \multicolumn{2}{|c|}{ Milestone } & \multirow{2}{*}{$\begin{array}{c}\text { WBS } \\
\text { Number }\end{array}$} & \multirow{2}{*}{\multicolumn{2}{|c|}{ Milestone Description }} & \multirow{2}{*}{$\begin{array}{l}\text { Due } \\
\text { Date }\end{array}$} \\
\hline Type & Number & & & & \\
\hline CNTR & FF.S-95-062 & 6.10 .4 .3 & \multicolumn{2}{|c|}{$\begin{array}{l}\text { Electronic Audit Analysis Software - Market survey } \\
\text { of the current Audit Analysis software packages. }\end{array}$} & $03 / 31 / 95$ \\
\hline CNTR & FFS-95-063 & 6.10 .4 .3 & \multicolumn{2}{|c|}{ Annual Call Letter } & $05 / 10 / 95$ \\
\hline RL & FFS-95-064 & 6.10 .4 .3 & \multicolumn{2}{|l|}{ Annual Audit Plan } & $06 / 30 / 95$ \\
\hline
\end{tabular}




\begin{tabular}{|c|c|c|c|}
\hline 2.C. 1 & $\begin{array}{l}\text { Cost Baseline } \\
\text { by Program } \\
\text { Element }\end{array}$ & $\begin{array}{c}\text { Hestinghouse Hanford Company } \\
\text { Finance and Administration } \\
\text { SMS/WBS } 6.10\end{array}$ & $\begin{array}{c}\text { FY } 1995 \text { SSPP } \\
\text { Date Prepared: } 08 / 31 / 94\end{array}$ \\
\hline
\end{tabular}

FY 1995 Cost Baseline (Dollars in Thousands)

\begin{tabular}{|l|l|r|}
\hline WBS \# & \multicolumn{1}{|c|}{ Title } & Total \$s \\
\hline 6.10 .4 .1 & Financial Administration & 1,727 \\
\hline 6.10 .4 .2 & Financial Operations & 13,468 \\
\hline 6.10 .4 .3 & Financial Review and Audits & 670 \\
\hline 6.10 .4 .4 & WHC Taxes and Insurance & 6,265 \\
\hline \multicolumn{2}{|r}{ FY 1995 Total for 6.10 .4} & 22,130 \\
\hline
\end{tabular}

FY 1996 Cost Baseline (Dollars in Thousands)

\begin{tabular}{|l|l|r|}
\hline WBS \# & \multicolumn{1}{|c|}{ Title } & Total \$s \\
\hline 6.10 .4 .1 & Financial Administration & 1,777 \\
\hline 6.10 .4 .2 & Financial Operations & 13,859 \\
\hline 6.10 .4 .3 & Financial Review and Audits & 689 \\
\hline 6.10 .4 .4 & WHC Taxes and Insurance & 6,447 \\
\hline & & FY 1996 Total for 6.10 .4 \\
\hline
\end{tabular}




\begin{tabular}{|c|c|c|c|}
\hline 2.C. 1 & $\begin{array}{l}\text { Cost Baseline } \\
\text { by Program } \\
\text { Element }\end{array}$ & $\begin{array}{c}\text { Westinghouse Hanford Company } \\
\text { Finance and Administration } \\
\text { SMS/WBS } 6.10\end{array}$ & $\begin{array}{c}\text { FY } 1995 \text { SSPP } \\
\text { Date Prepared: } \\
08 / 31 / 94\end{array}$ \\
\hline
\end{tabular}

FY 1997 Cost Baseline (Dollars in Thousands)

\begin{tabular}{|c|c|c|c|}
\hline WBS \# & Title & & Total \$s \\
\hline 6.10 .4 .1 & Financial Administration & & 1,831 \\
\hline 6.10 .4 .2 & Financial Operations & & 14,276 \\
\hline 6.10 .4 .3 & Financial Review and Audits & & 710 \\
\hline 6.10 .4 .4 & WHC Taxes and Insurance & & 6,641 \\
\hline & - & FY 1997 Total for 6.10 .4 & 23,458 \\
\hline
\end{tabular}




\begin{tabular}{|c|c|c|}
\hline 2.C.1.2 Cost Baseline by Funding & Westinghouse Hanford Company & FY 1995 SSPP \\
Source & Finance and Administration \\
SMS/WBS 6.10 & Date Prepared: \\
$08 / 31 / 94$
\end{tabular}

FY 1995 COST BASELINE (Dollars in Thousands)

\begin{tabular}{|c|c|c|c|c|c|c|c|}
\hline WBS \# & Title & Dept. $\mathrm{OH}$ & SWS & SLP & $G \& A$ & Direct \$ & TOTAL \$s \\
\hline 6.10 .4 .1 & $\begin{array}{l}\text { Financial } \\
\text { Administration }\end{array}$ & & & & 1,727 & & 1,727 \\
\hline 6.10 .4 .2 & $\begin{array}{l}\text { Financial } \\
\text { Operations }\end{array}$ & & 1,363 & & 11,099 & 1,006 & 13,468 \\
\hline 6.10 .4 .3 & $\begin{array}{l}\text { Financial } \\
\text { Review and } \\
\text { Audits }\end{array}$ & & & & 670 & & 670 \\
\hline 6.10 .4 .4 & $\begin{array}{l}\text { WHC Taxes and } \\
\text { Insurance }\end{array}$ & & & & 6,265 & & 6,265 \\
\hline & TOTALS & & 1,363 & & 19,761 & 1,006 & 22,130 \\
\hline \multicolumn{8}{|c|}{ FY 1996 COST BASELINE } \\
\hline 6.10 .4 .1 & $\begin{array}{l}\text { Financial } \\
\text { Administration }\end{array}$ & & & & 1,777 & & 1,777 \\
\hline 6.10 .4 .2 & $\begin{array}{l}\text { Financial } \\
\text { Operations }\end{array}$ & & 1,403 & & 11,421 & 1,035 & 12,456 \\
\hline 6.10 .4 .3 & $\begin{array}{l}\text { Financial } \\
\text { Review and } \\
\text { Audits } \\
\end{array}$ & & & & 689 & & 689 \\
\hline 6.10 .4 .4 & $\begin{array}{l}\text { WHC Taxes and } \\
\text { Insurance }\end{array}$ & & & & 6,447 & & 6,447 \\
\hline \multicolumn{2}{|r|}{ TOTALS } & & 1,403 & & 20,334 & 1,035 & 22,772 \\
\hline
\end{tabular}

Financial Services $6.10 .4 \quad 2 C-3$ 


\begin{tabular}{|c|c|c}
\hline 2.C.1.2 Cost Baseline by Funding & Westinghouse Hanford Company & FY 1995 SSPP \\
Source & Finance and Administration \\
SMS/WBS 6.10 & $08 / 31 / 94$
\end{tabular}

\begin{tabular}{|c|c|c|c|c|c|c|c|}
\hline WBS \# & Title & Dept. $\mathrm{OH}$ & SWS & SLP & $G \& A$ & Direct \$ & TOTAL \$s \\
\hline 6.10 .4 .1 & $\begin{array}{l}\text { Financial } \\
\text { Administration }\end{array}$ & & & & 1,831 & & 1,831 \\
\hline 6.10 .4 .2 & $\begin{array}{l}\text { Financial } \\
\text { Operations }\end{array}$ & & 1,445 & & 11,765 & 1,066 & 14,276 \\
\hline 6.10 .4 .3 & $\begin{array}{l}\text { Financial } \\
\text { Review and } \\
\text { Audits } \\
\end{array}$ & & & & 710 & & 710 \\
\hline 6.10 .4 .4 & $\begin{array}{l}\text { WHC Taxes and } \\
\text { Insurance }\end{array}$ & & & & 6,641 & & 6,641 \\
\hline & TOTALS & & 1,445 & & 20,947 & 1,066 & 23,458 \\
\hline
\end{tabular}




\begin{tabular}{|l|c|c|}
\hline 2.C.2 Cost Basis & $\begin{array}{c}\text { Westinghouse Hanford Company } \\
\text { Financial and Administration } \\
\text { SMS/WBS No.6.10 }\end{array}$ & $\begin{array}{c}\text { Fy } 1995 \\
\text { Site Support Program P7an } \\
\text { Date Prepared: 08/31/94 }\end{array}$ \\
\hline
\end{tabular}

Labor costs based on the identified hours required to perform each element's identifiable activities. Resulting FTEs are based on these hours and priced according to the labor rate guidance as reflected in the Financial Data, System.

Non-labor cost elements, primarily service assessments, are based on planning guidance from utilized services (i.e., BCSR, etc.). Supplies, training, and travel aré based on consideration of historical usage plus quantitative knowns for the next fiscal year. 


\begin{tabular}{|c|c|c|}
\hline 2.C.3 FTE Forecasts & $\begin{array}{c}\text { Westinghouse Hanford Company } \\
\text { Finance and Administration } \\
\text { SMS/WBS No. 6.10 }\end{array}$ & $\begin{array}{c}\text { FY 1995 } \\
\text { Site Support Program P1an } \\
\text { Date Prepared: } 08 / 31 / 94\end{array}$ \\
\hline
\end{tabular}

\section{Financial Services}

WBS 6.10.4

The information for this section of the Financial Services SSPP is still under consideration due to the current downsizing impact due to Bechtel Hanford, Inc., and WHC restructuring. 


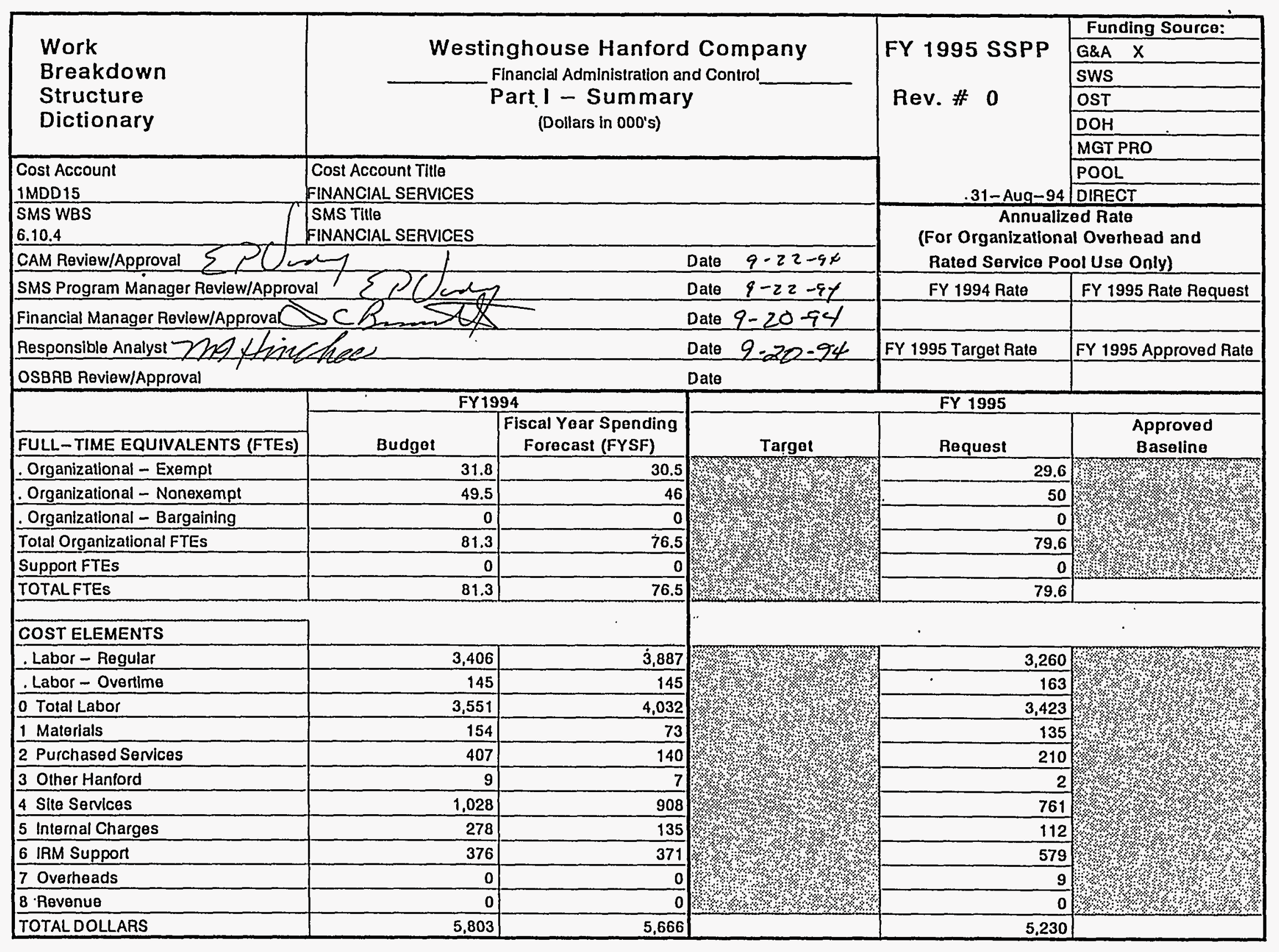




\begin{tabular}{|l|c|c|}
\hline $\begin{array}{l}\text { 1MDD1500 } \\
\text { COSTACCOUNT }\end{array}$ & \multicolumn{2}{|c|}{ FY 1995 SSPP } \\
\hline $\begin{array}{l}\text { Work Breakdown } \\
\text { Structure } \\
\text { Dictionary }\end{array}$ & Festinghouse Hanford Company & Finaliadministration and Control \\
\cline { 2 - 3 }
\end{tabular}

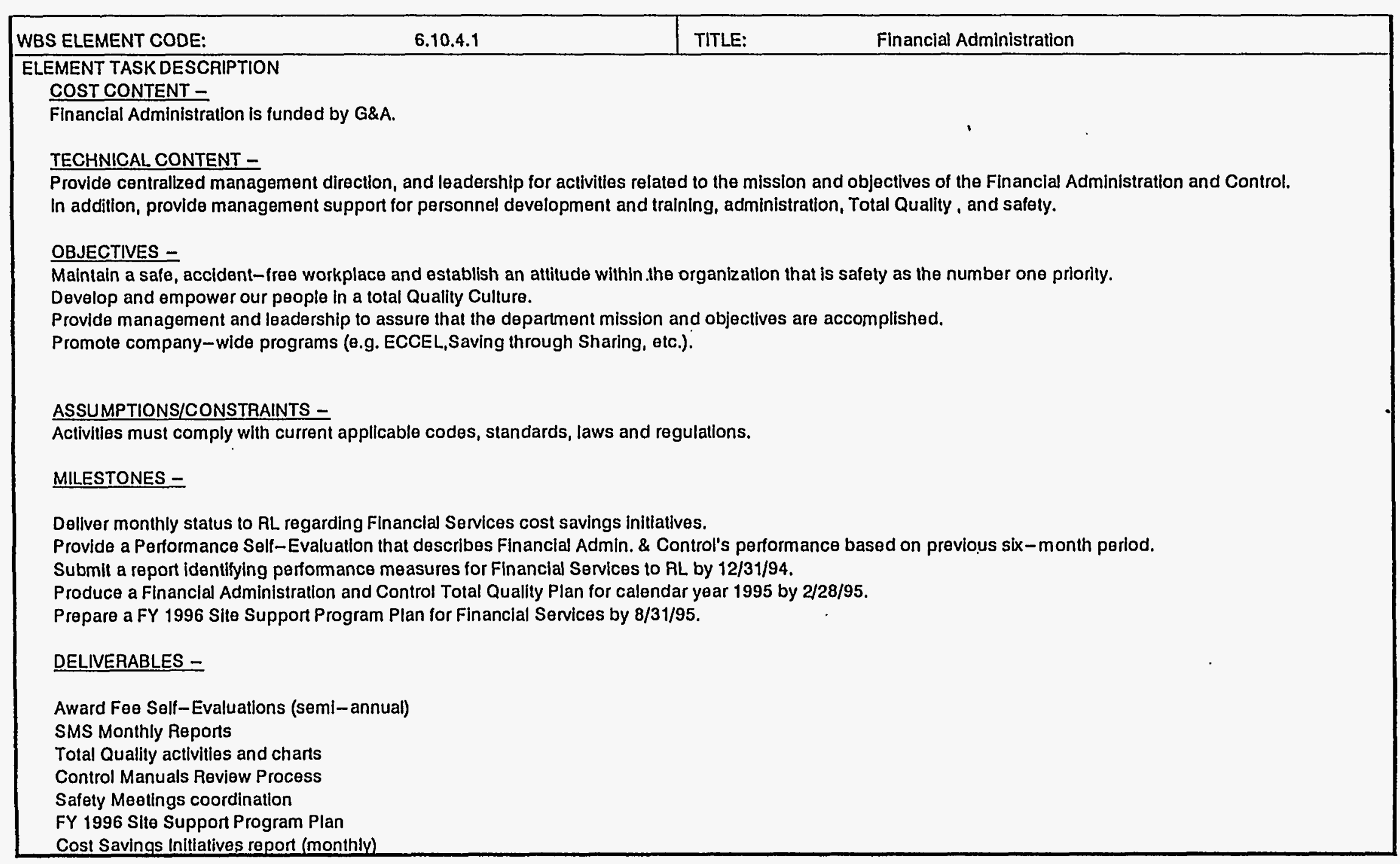




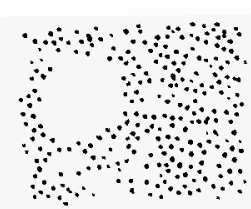

\begin{tabular}{|l|l}
\hline Cost Account 1MDD1500 & Part II - Element Definition (continued) \\
\hline
\end{tabular}

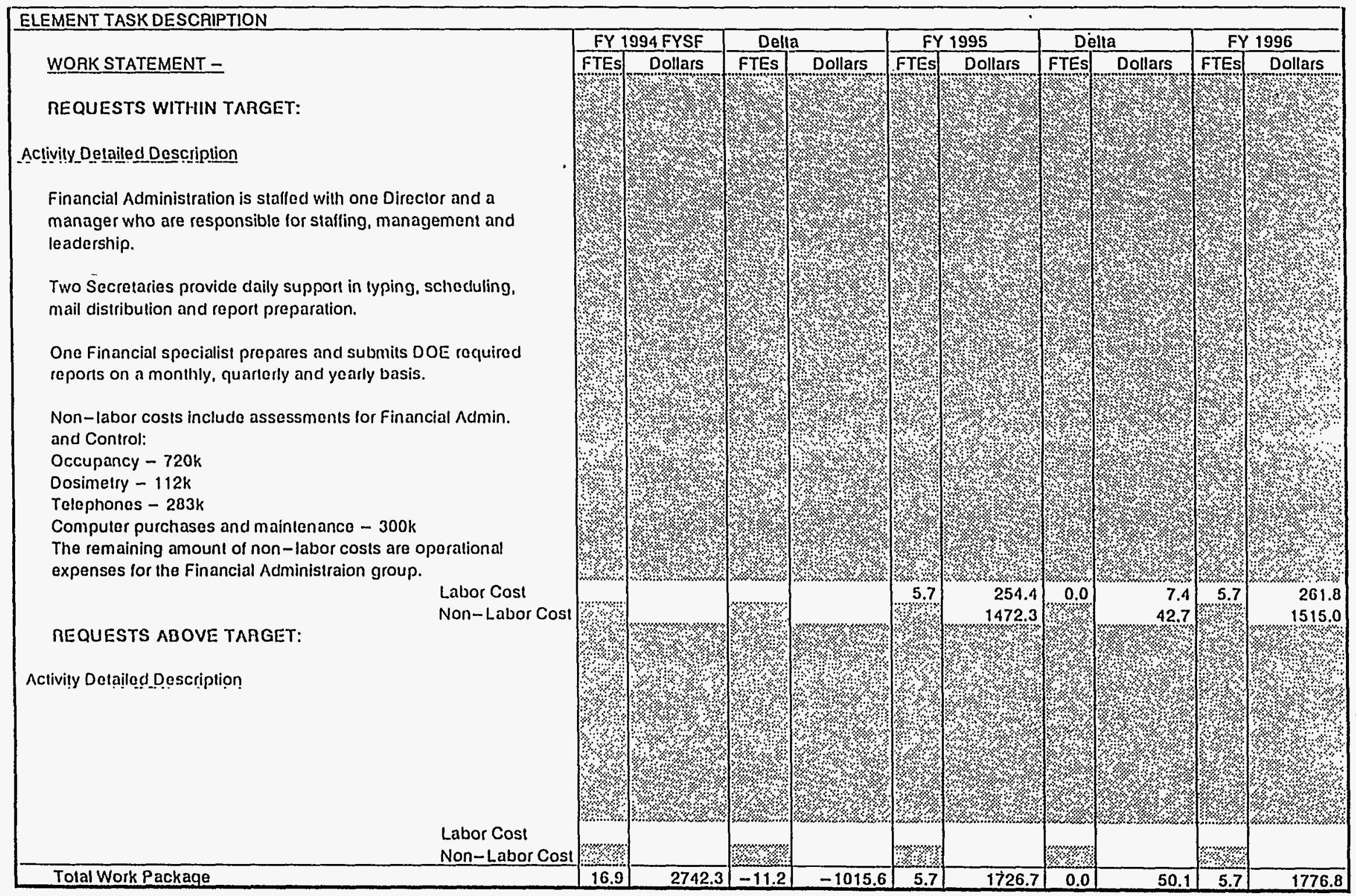




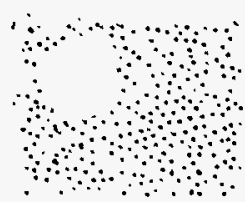

\begin{tabular}{|c|c|c|}
\hline $\begin{array}{l}1 \text { MDD } 1500 \\
\text { COST ACCOUNT }\end{array}$ & & \\
\hline $\begin{array}{l}\text { Work Breakdown } \\
\text { Structure } \\
\text { Dictionary }\end{array}$ & $\begin{array}{l}\text { Westinghouse Hanford Company } \\
\text { Financial Administration and Control } \\
\text { Part II - Element Definition }\end{array}$ & $\begin{array}{l}\text { FY } 1995 \text { SSPP } \\
\text { Revision \# } 0\end{array}$ \\
\hline
\end{tabular}

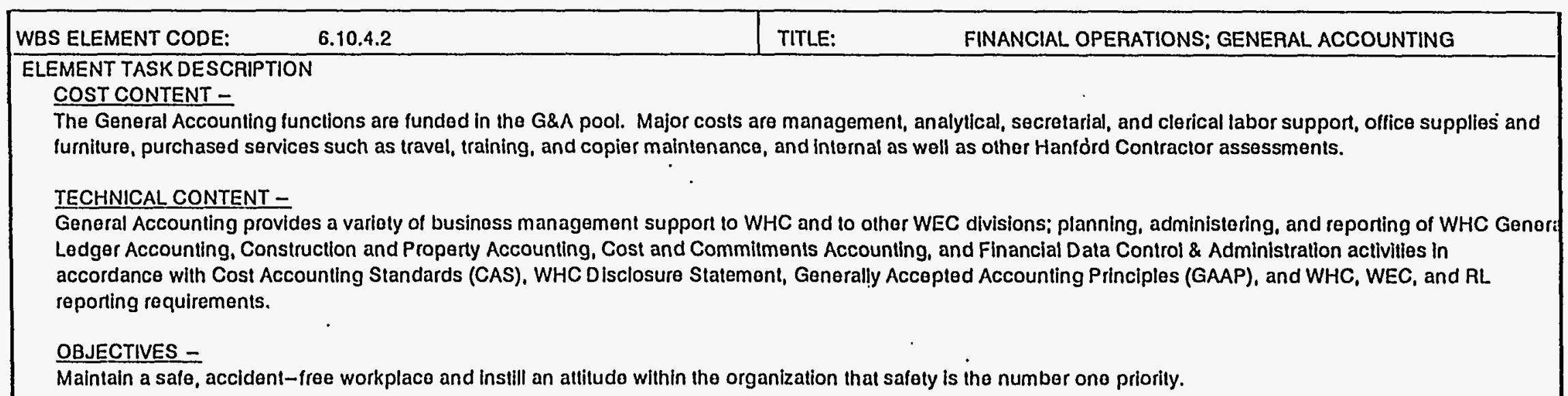

Ensure financial integrily in all Goneral Accounting operations, Including compliance with applicable codes, standards, laws, and regulations.

Provide financlal support, control, and accounting processes to assure consistent and disclplined financial management of resources, programs, and organizations. Provide linanclal data, reports and analysis of the financial status and perfomance of WHC programs and organizations.

Establish a system of management controls that provides a reasonable assurance that financlal operations are officlent and effective and that inappropriate and unallowable costs are minimized.

Identify and request accounting and performance measurement system developments and enhancements to provide ongoing site mission suppon.

ASSUMPTIONS/CONSTRAINTS -

Incompatiblity of $M \& O(W H C)$ and $N o n-M \& O(B H I)$ contractual relationship responsible for additional Financial Services labor requirements.

\section{MILESTONES -}

Prepare updated Disclosure Statement

$01 / 01 / 95$

Prepare financial data input to DISCAS and FIS

$10 / 94-9 / 95$

Prepare annual updated Property Record Unil catalog

$06 / 15 / 95$

Prepare annual financlal statement

$11 / 94$

Preparo startup and closing schedulo for FY 1995 and FY 1996

$07 / 15 / 95$ 


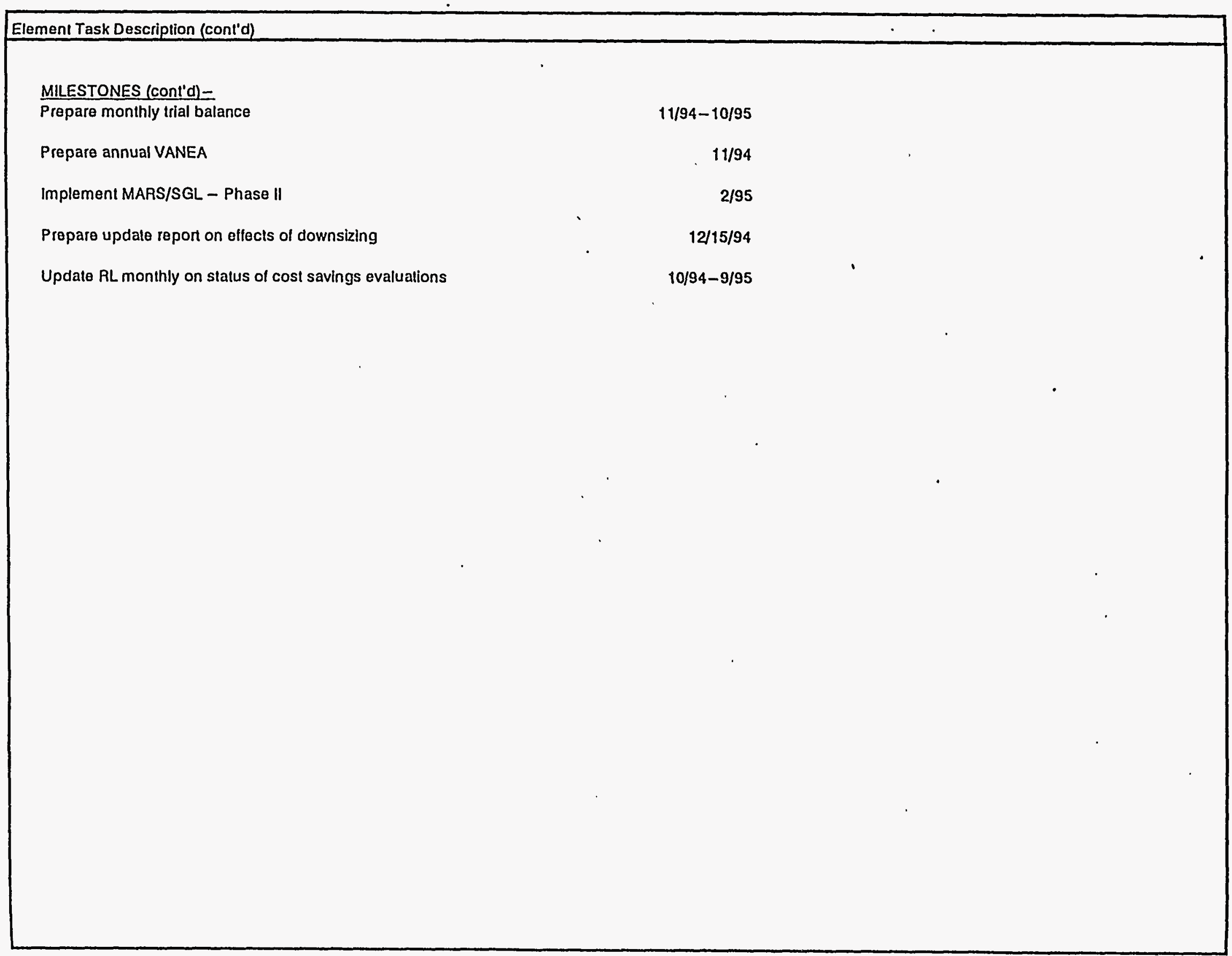




\section{DELIVERABLES -}

\section{Annual}

Tax Reports (Blue Book)

Vending Machine Revenue

Nuclear Material Accountability

Budget Guidelline Handbook

Standard Labor Rates

Labor by Category

CAA Automation

Capital Robaselining

Propenty Record Unit Catalog

Disposition of Unliquidated Constructlon Project Accruals

\section{Quarterly}

Schedule B

SF220.9 Report

Conference Activities

Federal Excise Taxes - Gasoline \& Dlesel

Status of Accrued Construction Projects

\section{Monthly}

General Ledger Subaccount Reconclllations

Corporate Accounts Recelvable

Reconciliation Status

Washington State Excise Tax Relurn

Systems (DISCAS, FDS, etc) Reconclliatlons

ADS/TTP Number Valldations

Nuclear Materials Accountabillty

Balance Sheet

Corporate Expense Report

Subsidiary Debt Status

Accounts Recelvable Payments

FDS/MCS Overview Tralning Class

FDS System Reporting Training Class

Projoct Analysls \& Reporting System Tralning Class
Identification of Nuclear Waste Fund Plant \& Capital Equipment

Richland and Spokane Business Licenses.

Tax Subscription Renewals

Fiscal Year Startup Workshop

Escalatlon Study

Fiscal Year Reallzed Hours

Funds Control/Funds Management

Scheduling/FDS integration

FDS Users Group

Washington State Gasolline Tax Refund

Washington State Dlẹsel Excise Tax Payment

Dividend Declaration

Abandoned Projects

Conflrmation with other Offices

Employee Store Reconcillations

Trlal Balance

FDS General Ledger Table Maintenance

B\&R Number Valldations

B\&R Cost Code Corrections

Accounts Recelvable

Cash Recelpts

Data Type 19 Report

DISCAS

Isotope Activity

Financlal Reporting/Soft Reporting Training Class

FDS Budgeting Training Class

Non-Fund Depreciation Billing 


\section{WORK STATEMENT -}

\section{REQUESTS WITHIN TARGET:}

\section{$\angle A B O R$ (continued)}

General Ledger Accounting - 1 Manager; 4 Speciatists; 2 Clerks; 1 Temporary Specialist (Summer)

Establish and maintain accounting policies, procedures, and system of accounts which meet the accounting and reporting requirements of RL, WHC, WEC, as well as state and federal taxation authorities, in a manner that is consistent with GAAP and CAS.

Analyze accounting acivity to identify charges unallowable under the WHC/RL contract and decide the disposition; advise management on reimbursement questions; maintain an accurate accounting for all nonreimburseable charges; provide counsel on corporate financial planning activities; manage corporate receivables in support of WEC financial objectives.

Indentify and develop improvements and efficiencies in manual and ADP systems and reports.

Provide consultation and analysis to WHC management on all local, state, and federal tax issues; serve as liason with WHC legal counsel and WEC in tax matters.

Consult with internal and external auditors on financial audits involving the general ledger and assist in deficiency resolution; aggressively negotiate audit findings of external auditors related to interpretation of state and federal regulations.

Direct monthly and fiscal year end closing financial statement activities to meet RL and HQ schedules and goals.

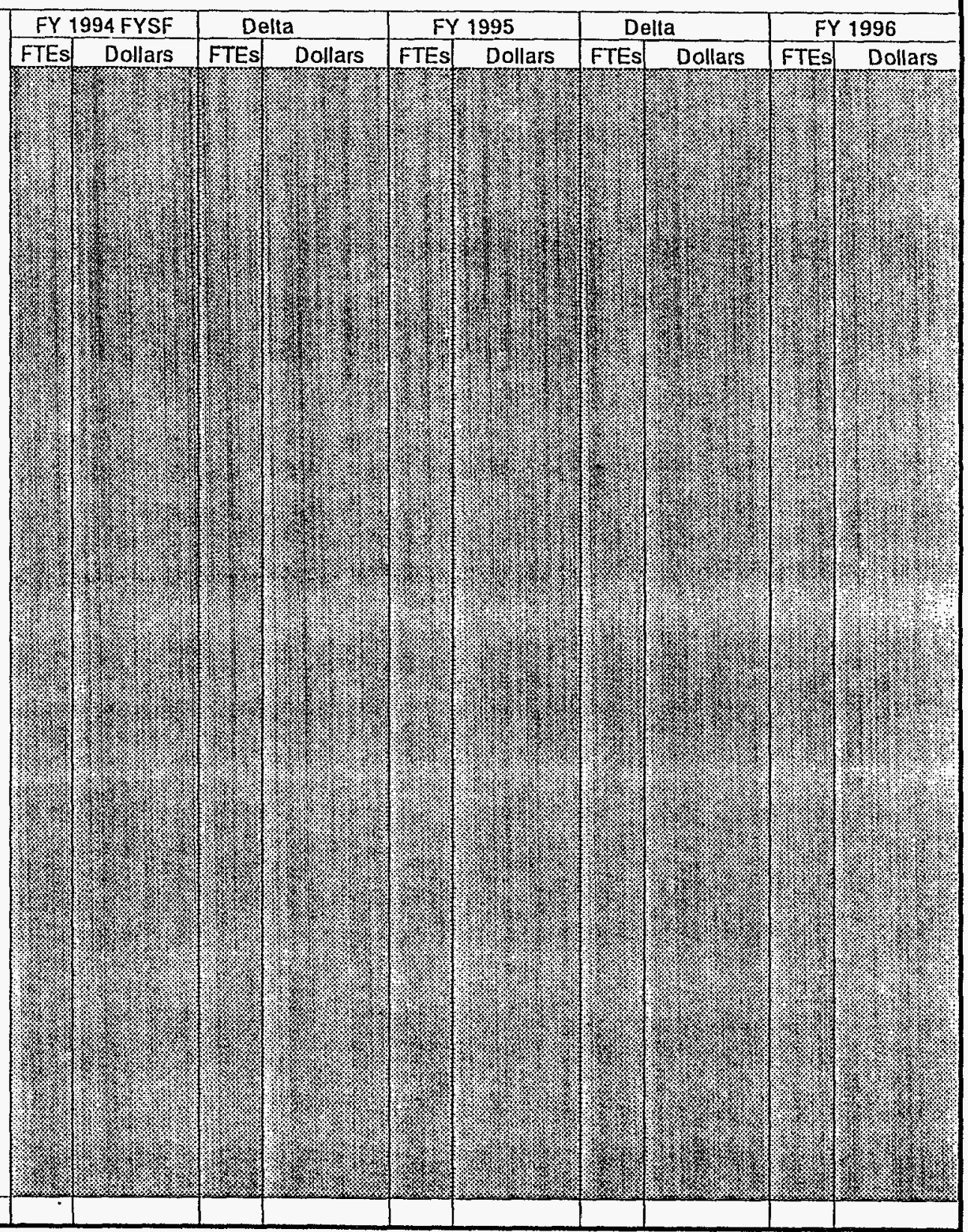




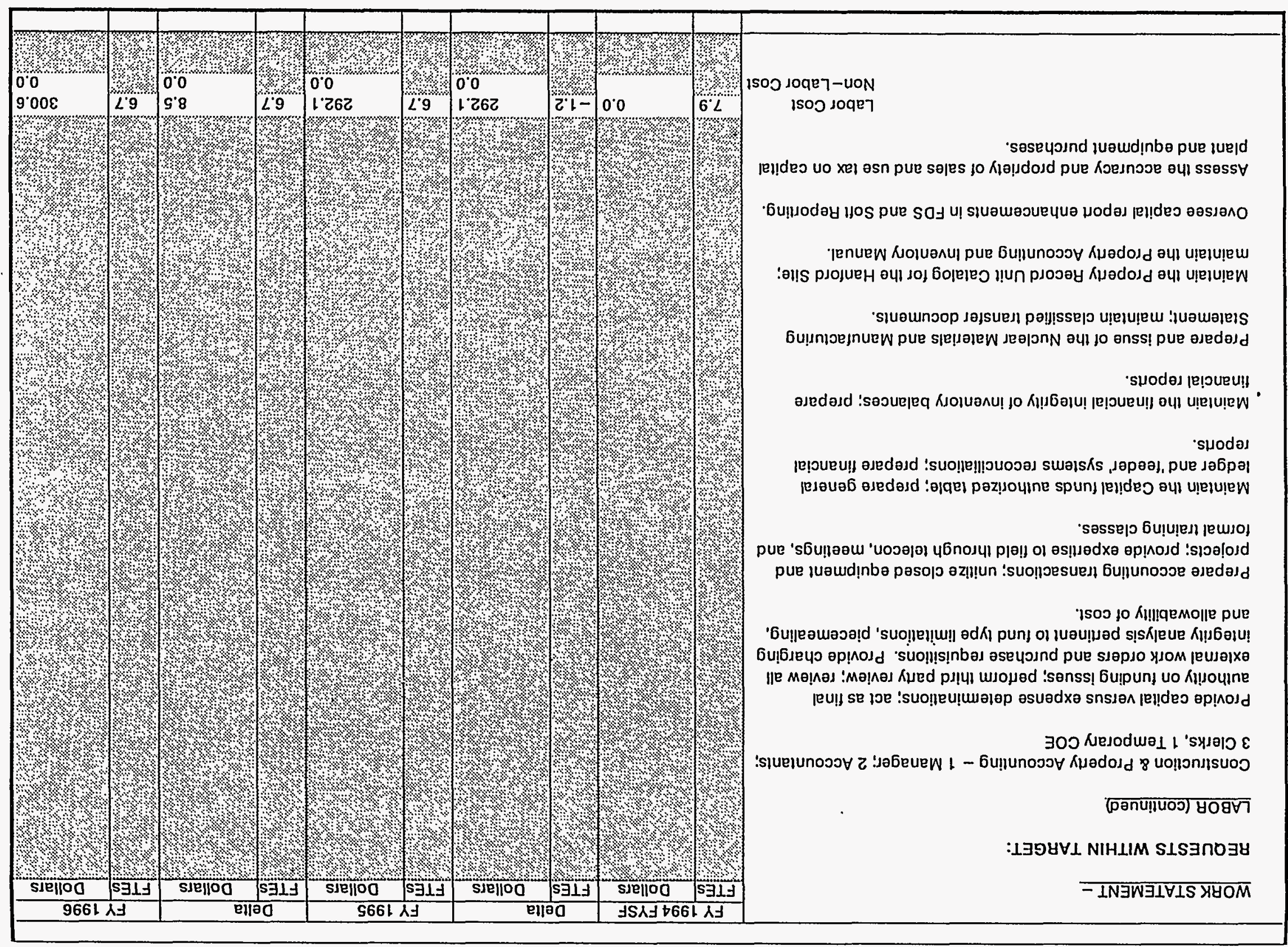

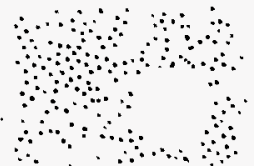




\section{WORK STATEMENT -}

\section{REQUESTS WITHIN TARGET:}

\section{LABOR (continued)}

Cost \& Commitments Accounting - 1 Manager; 3 Specialists; 4 Clerks; 1 Temporary Specialist (Summer); 1 Temporary COE

Maintain and control Special Requests including RL, other DOE, other Federal, other Westinghouse, and çommercial.

Maintain, distribute assessments, and reconcile self-liquidating pools.

Maintain a mechanism by which to report undistributed costs to responsible program managers.

Maintain and control system of accounts for recording and reporting of costs including reconciliations, cost transfers, and ModMasts.

Review purchase requisitions, Requests for Proposal, exlernal work orders, and other source documents for accuracy. allowability, and required infomation and signatures.

Conduct fiscal year startup and closing activities.

Oversee expense report enhancements in FDS and Soft Reporting

Labor Cost Non-Labor Cos

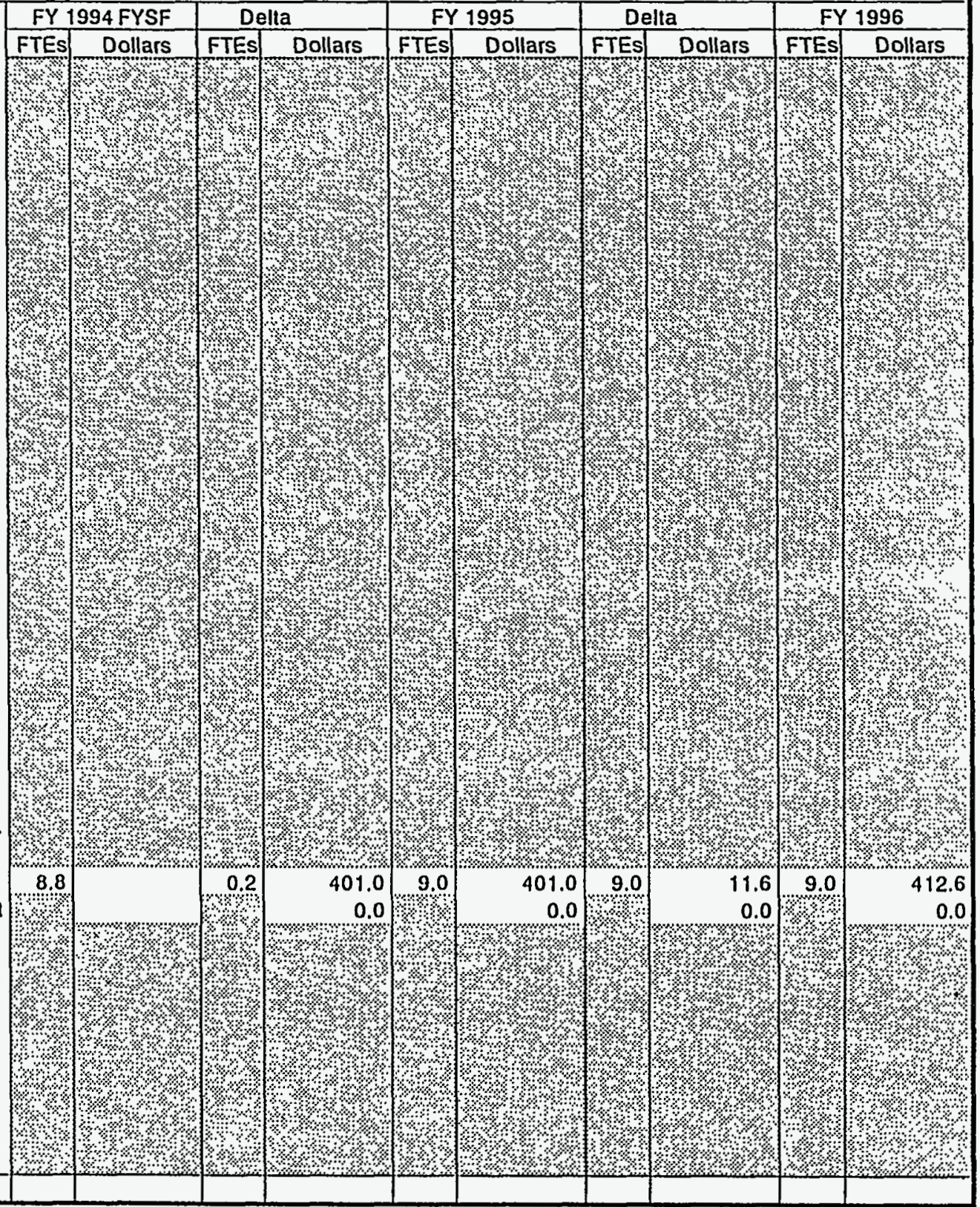




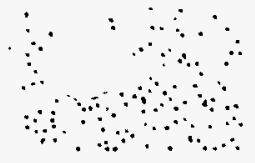

\section{WORK STATEMENT -}

\section{REQUESTS WITHIN TARGET:}

\section{LABOR (conlinued)}

Financial Data Control \& Administration - 1 Manager, 4 Analysts; 1 Clerk

Provide guidance to financial personnel through monthly FDS Iraining classes, the Fiscal Year Budget Guldeline Handbook, and the Fiscal Year Startup Workshop.

Develop standard labor rates, escalation study, and company realization hours to ensure consistent company wide application of planning and costing rates.

Maintain and control FDS tables, including SMS/WBS,

organization, work order, capilal funding, and other feeder system.

Provide orderly and timely monthly processing of the FDS to provide managers and support personnel with accurate data.

Oversee general ledger, capital, expense, and performance measurement report enhancements and refinements in FDS and Solt Reporting to ensure proper recording of financial transactions and efficient sile wide financial reporting.

Provide financial support to site personnel by acting as System Administrator, scheduling/planning/budget support interface. preparing ad-hoc reports, and fielding customer requests.

Lead team in developing the scheduling data into FDS budget integration, which will be used to develop budget and performance (BCWP) data in FDS

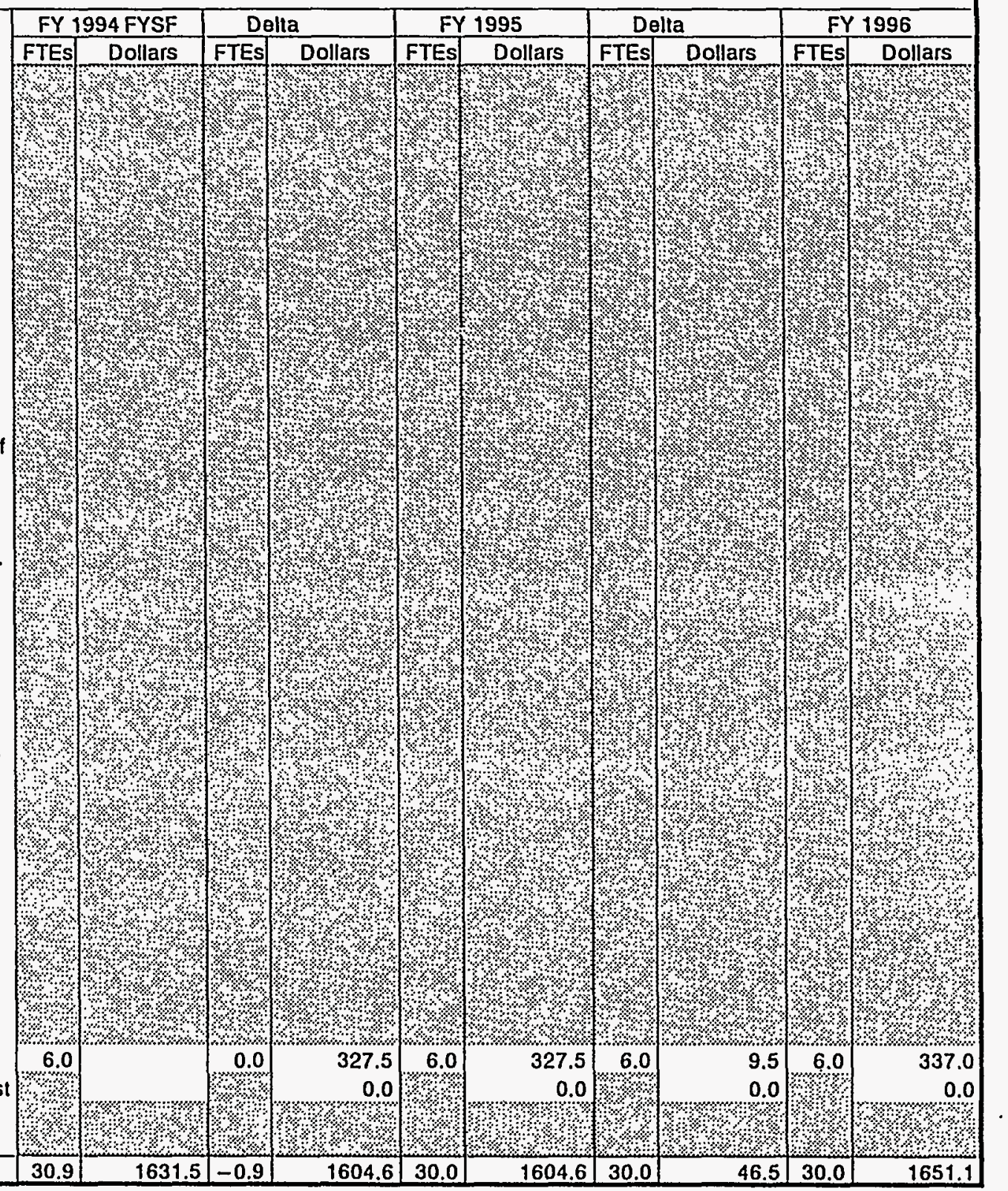




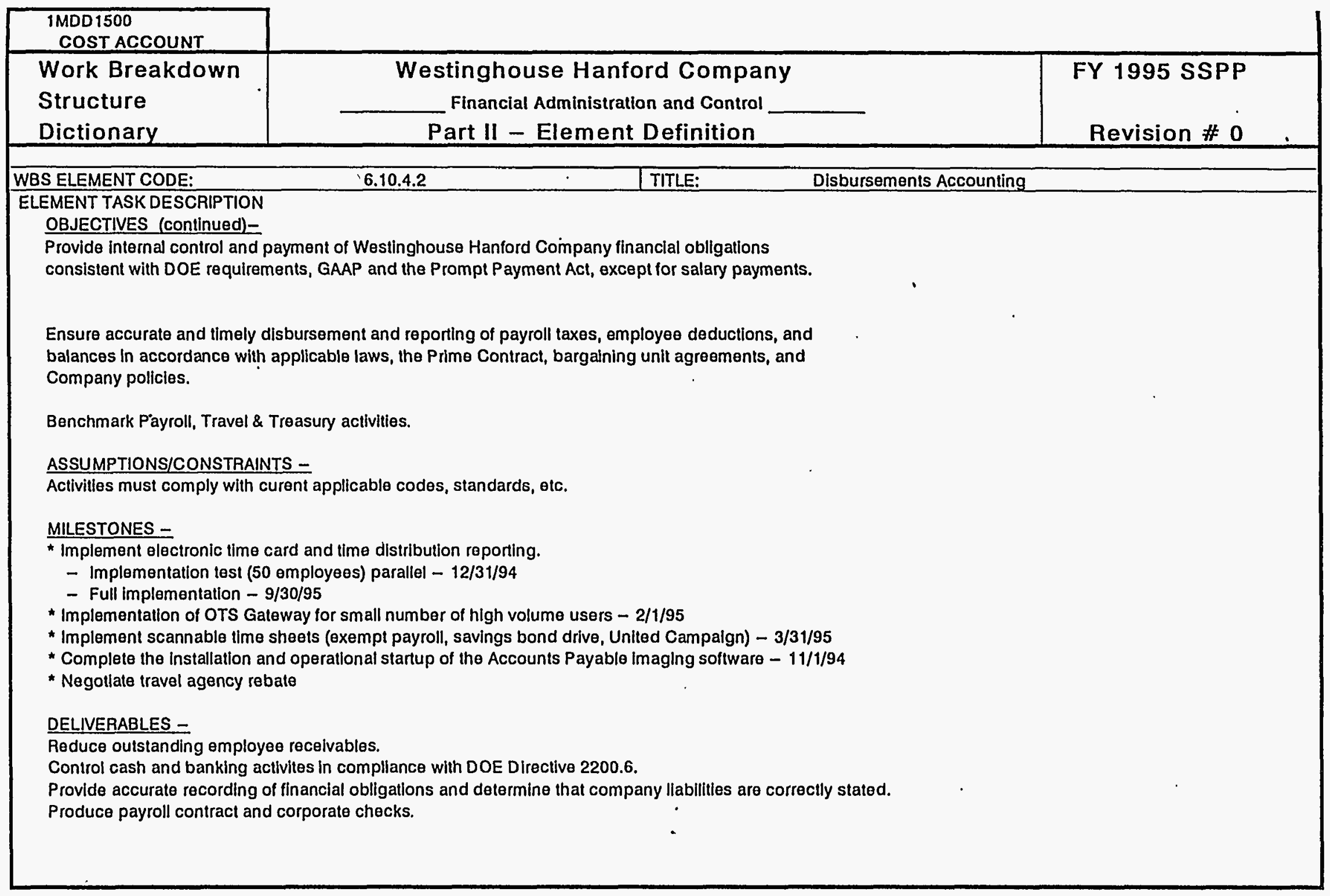




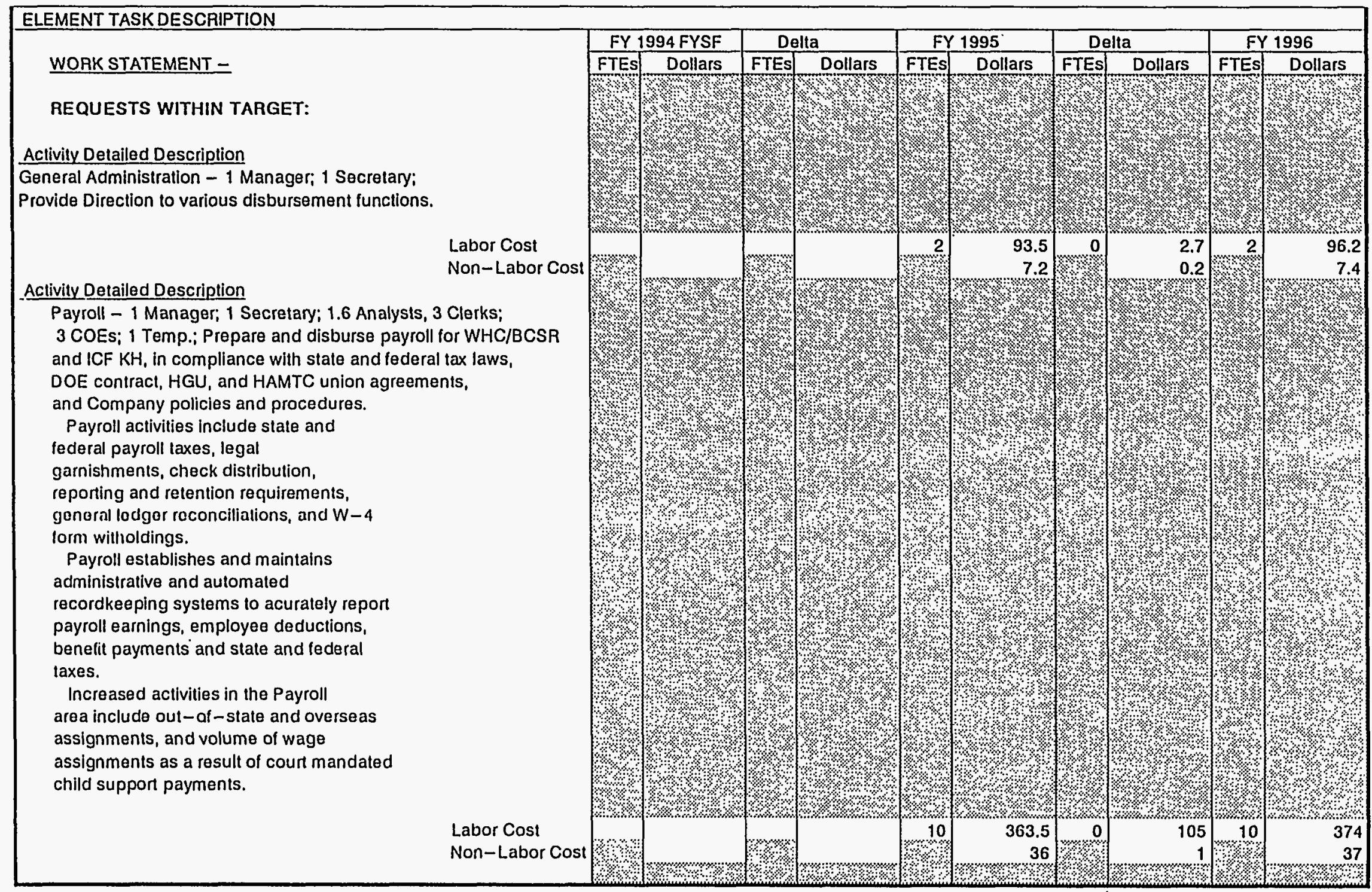




\section{WORK STATEMENT -}

\section{REQUESTS WITHIN TARGET:}

Activity Detailed Description

Salary Preparation - 1 Manager; 1 Analyst, 10.8 Clerks; Activities include salary preparation, issuance of $W-2$ forms, authorized deductions and timecards.

Salary Preparation calculates and pays WHC/BCSR and ICF KH employees. Increased activities in Salary Preparation include the addition and maintenance of 400 work shifts, and complex labor language.

Activity Detailed Description

Travel \& Treasury Services - 1 Manager; 3 Analysts; 13 Clerks; 3 COEs; Activities include cashiering, cash receipting, banking, administering a bus pass system,

preparation, auditing and distribution of contract and corporate checks, and reconciliation of contract, payroll and corporate bank accounts to General Ledger. Also the audit of expenses incurred for business travel, meetings,

relocation, temporary assignments for supporing documentation, and compliance with company policy and contract allowability.

Must establish internal controls on the disbursement and receipt of funds to prevent fraud and abuse.

Activities must be conducted to comply with the DOE/WHC contract, DOE orders, Federal travel regulations and company policies and procedures.

Total Work Package

Labor Cost
Non-Labor Cost

Labor Cost

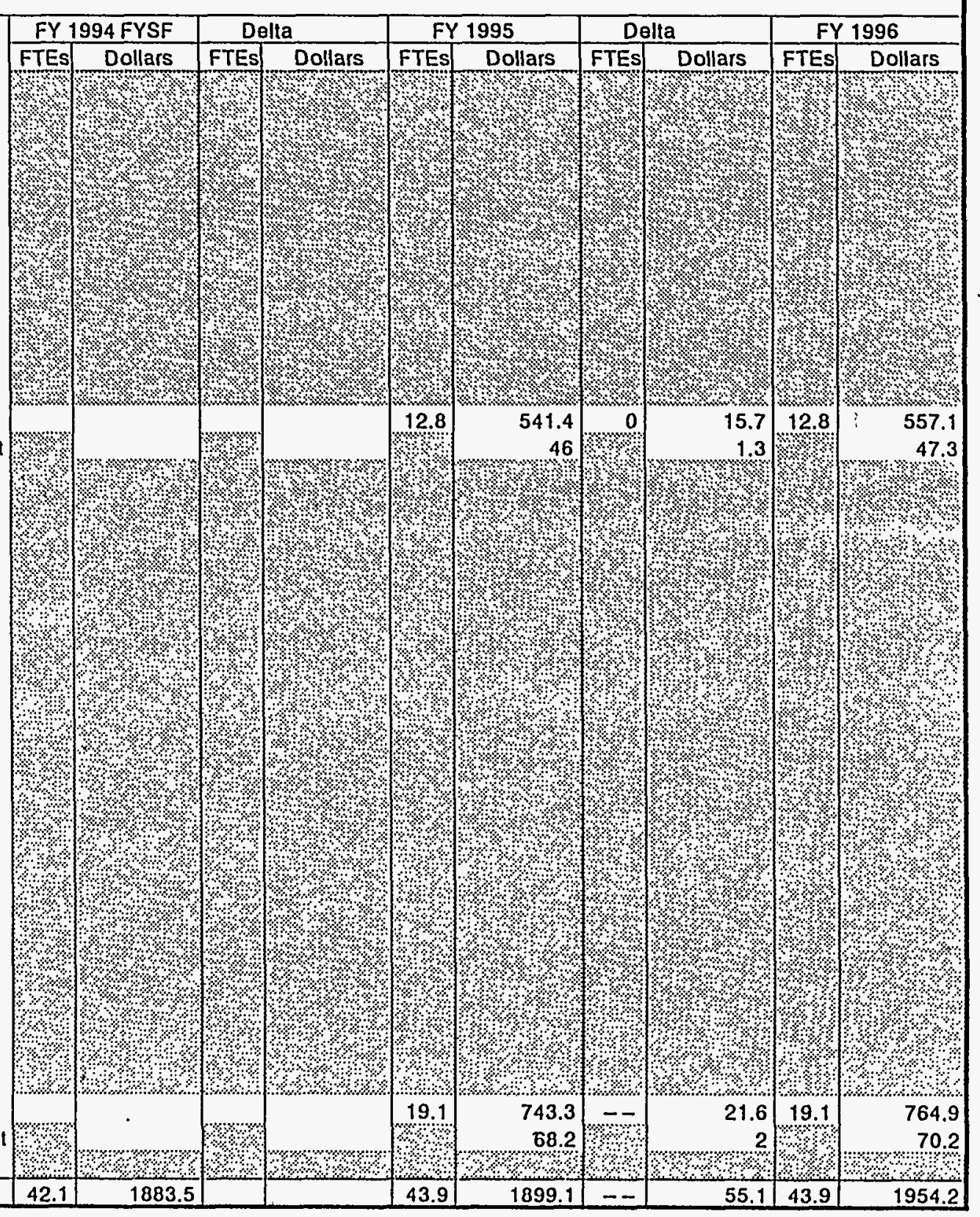




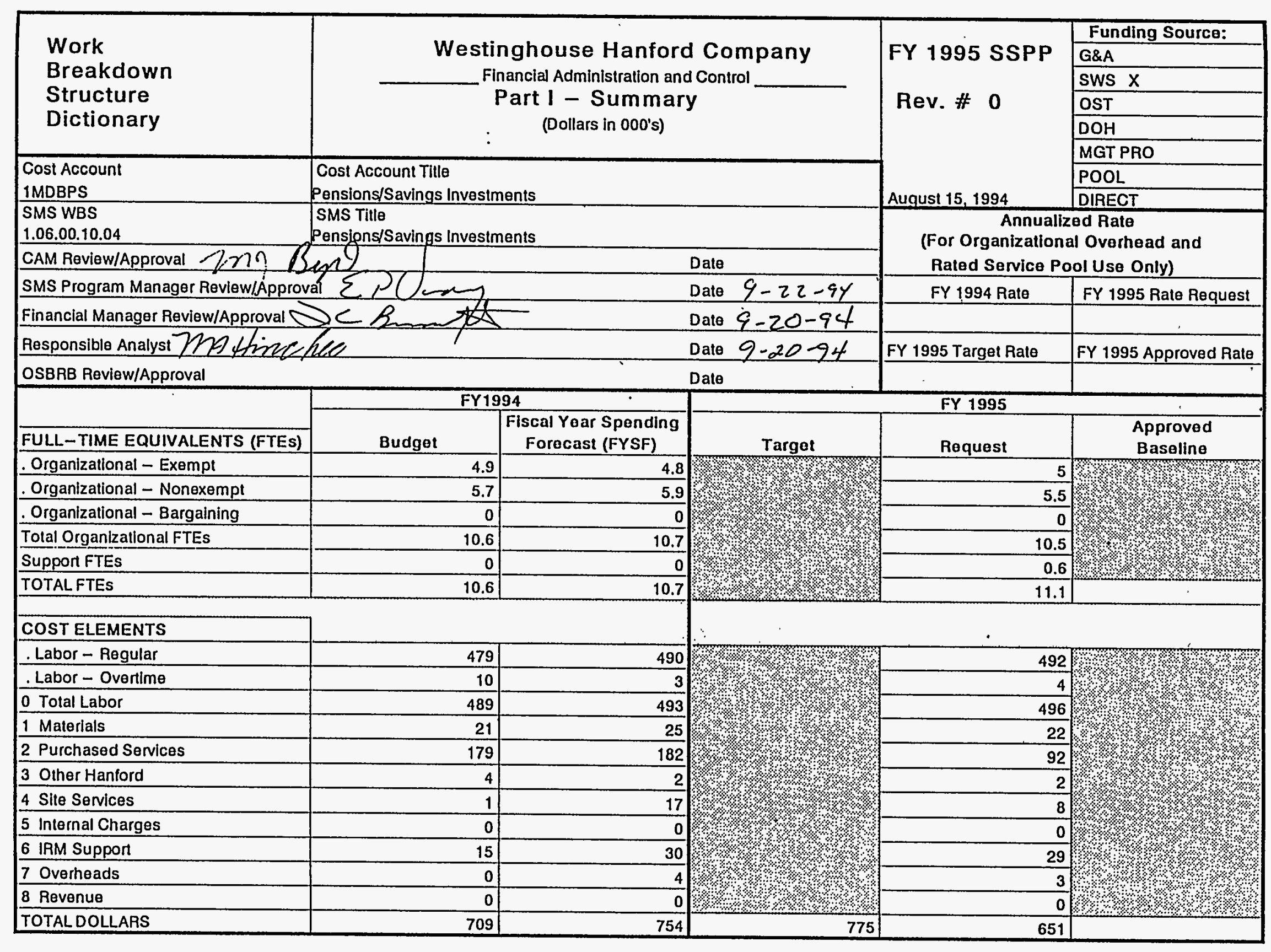




\begin{tabular}{|l|c|c|}
\hline $\begin{array}{l}\text { 1MDBPS } \\
\text { COST ACcounr }\end{array}$ & FY 1995 SSPP \\
\hline $\begin{array}{l}\text { Work Breakdown } \\
\text { Structure } \\
\text { Dictionary }\end{array}$ & $\begin{array}{c}\text { Westinghouse Hanford Company } \\
\text { Financial Administration and Control }\end{array}$ & Revision \#0 \\
\hline
\end{tabular}

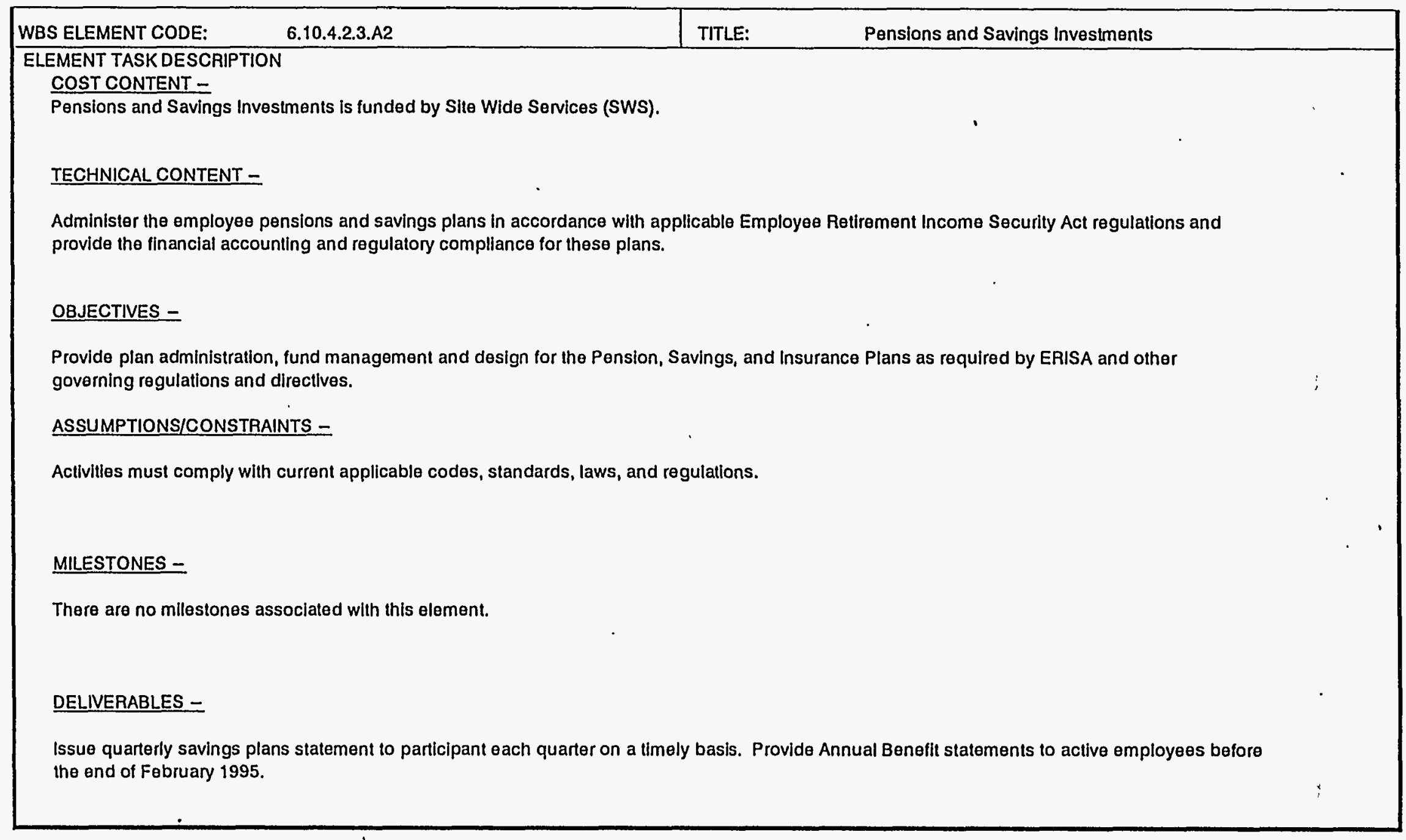




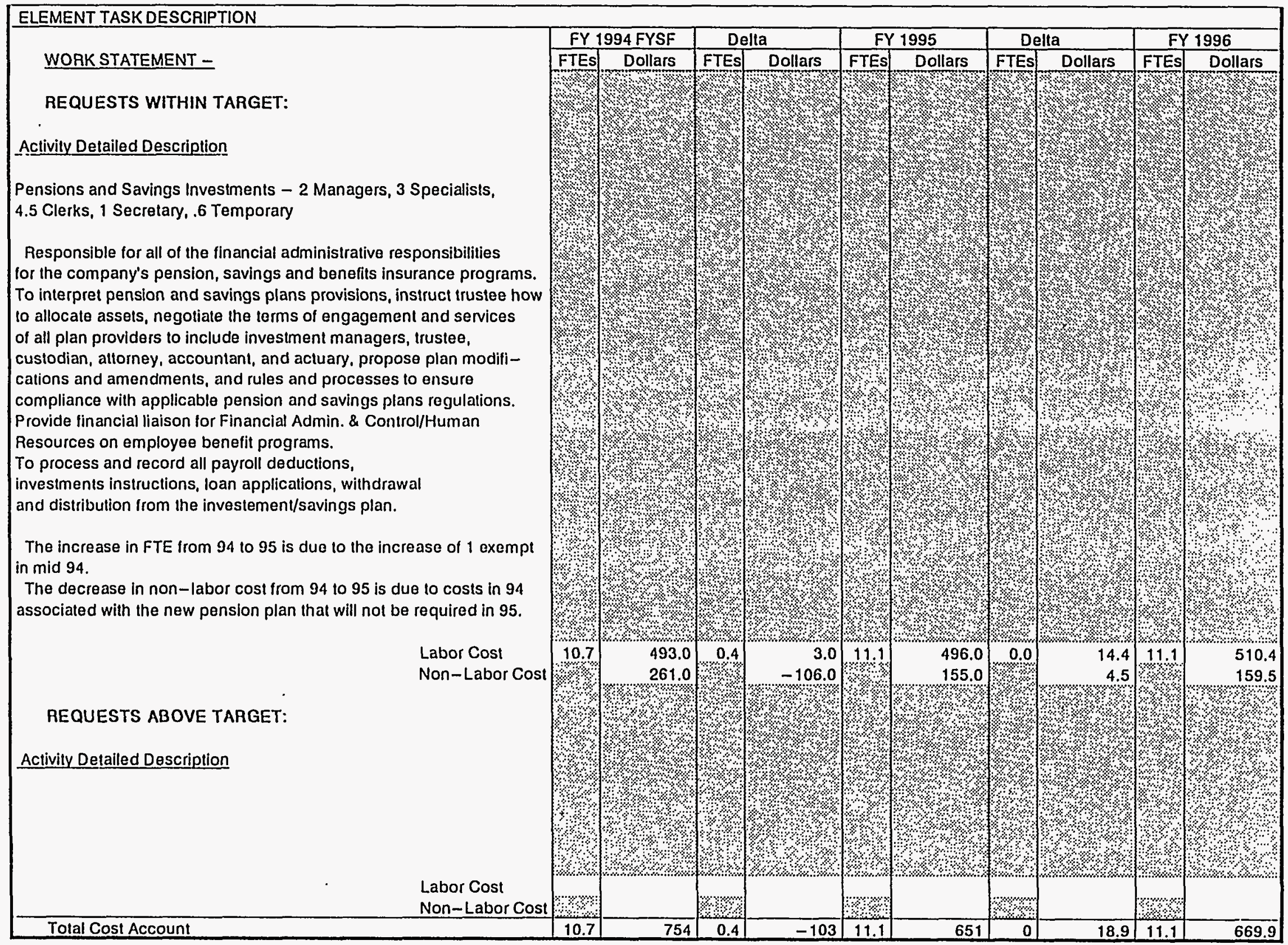




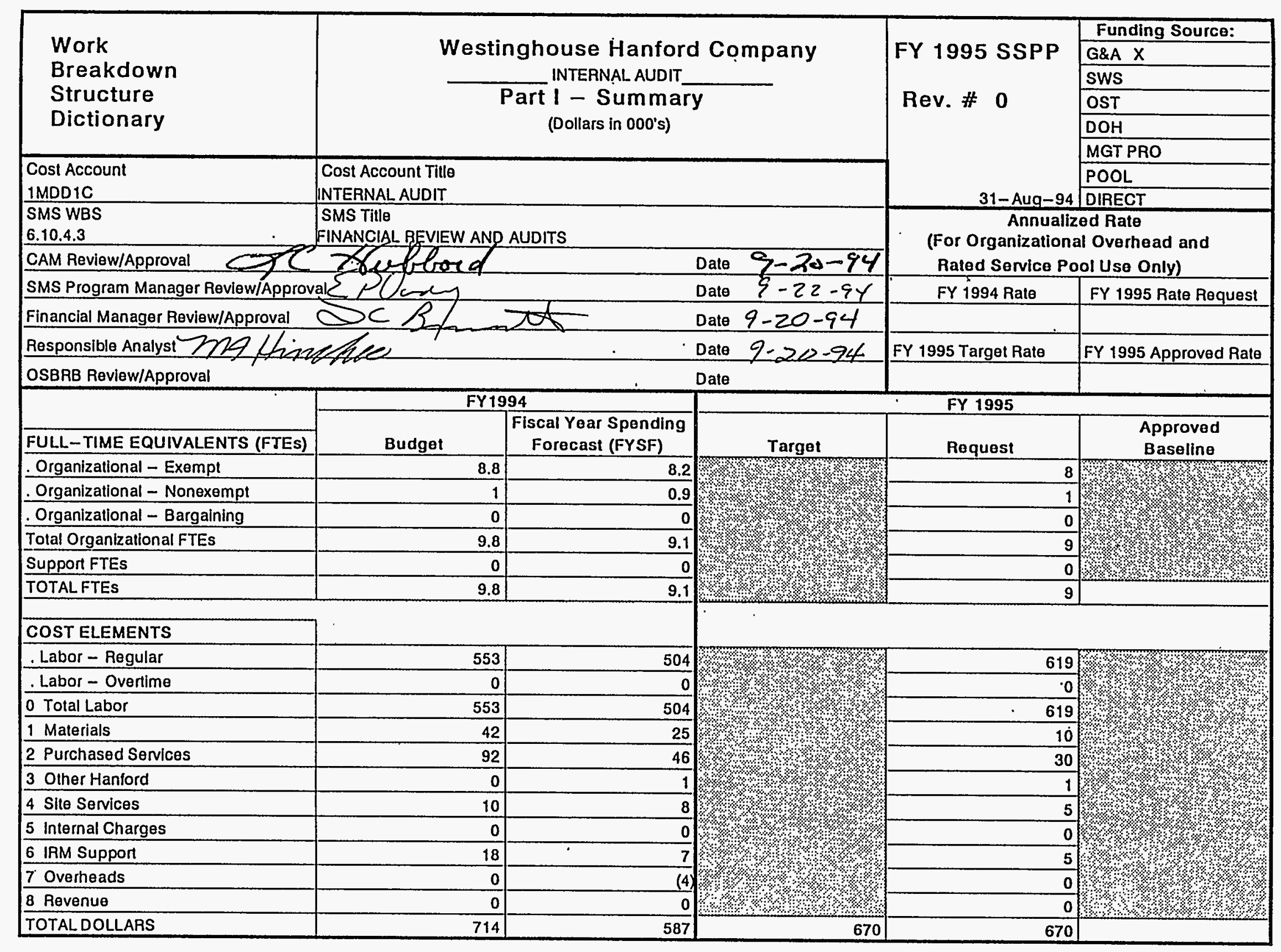




\begin{tabular}{|l|c|c|}
\hline $\begin{array}{l}\text { 1MDD1C } \\
\text { COST ACCOUNT }\end{array}$ & \multicolumn{2}{|c|}{ FY 1995 SSPP } \\
\hline $\begin{array}{l}\text { Work Breakdown } \\
\text { Structure } \\
\text { Dictionary }\end{array}$ & Westinghouse Hanford Company & Revision \# 0 \\
\hline
\end{tabular}

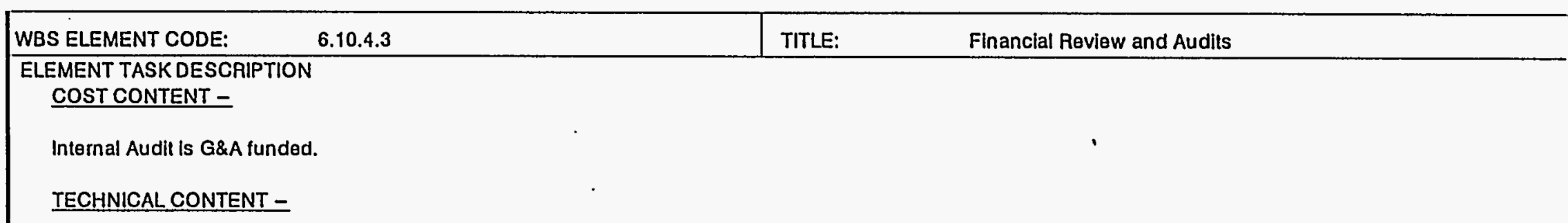

Develop and administer annual audit plans to identify internal controls issues and comply with DOE directives and contract.

Provide support to other agencies' audit requests and coordinate external auditsas appropriate.

\section{OBJECTIVES -}

Provide adequate oversight through surveillances, reviews, and internal audits based on an analysis of audit risks.

\section{ASSUMPTIONS/CONSTRAINTS -}

Activilies must comply with the DOE contract, Professional Auditing Standards, etc.

\section{MILESTONES -}

Issue call letter for FY 1995 Audit Plan by May 10, 1995.

Complete planning process for FY 1995 Audit Plan by June 30, 1995

Rrepare quarterly DOE Audit Report Tracking System (DARTS) and audit status report to RL.

Prepare annual IG Audit Summary Report by January 31, 1995.

Initlate and complete Audit finding correction action follow-up process each quarter.

Complete annual allowable cost audit for prior FY by December 30, 1994.

Complete electronic auditing study by December 31, 1994.

Conduct market survey of audit application software by March 31, 1995.

\section{DELIVERABLES -}

Issue annual audit plan/schedule to RL by July $1,1995$.

Issue internal audit reports.

Perform audit follow - up on corrective actions.

Coordinate external audits and responses to OIG and GAO audit reports as requested by RL.

Submil quarterly DOE Audit Report Tracking System (DARTS) and Audit Status Report to RL (10 working days at the end of each quarter)

Issue annual IG Audit Summary Report by January 31, 1995.

Issue report on electronic audlting study by January 31, 1995.

Issue report on audit application software_survey by March $30_{1 .} 1995$. 


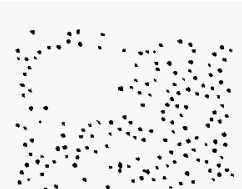

Cost Account 1MDD1C

\section{Part II - Element Definition (continued)}

ELEMENT TASK DESCRIPTION
WORK STATEMENT -
REQUESTS WITHIN TARGET:
Activity Detailed Description
1 Manager to provide planning, direction, and coordination
of the Internal Audit Function.
7 Auditors to perform the audits scheduled and approved in
accordance with the Prime Contract.
i Secretary to provide administrative support to the manager
and audit staff.

and audit staff.

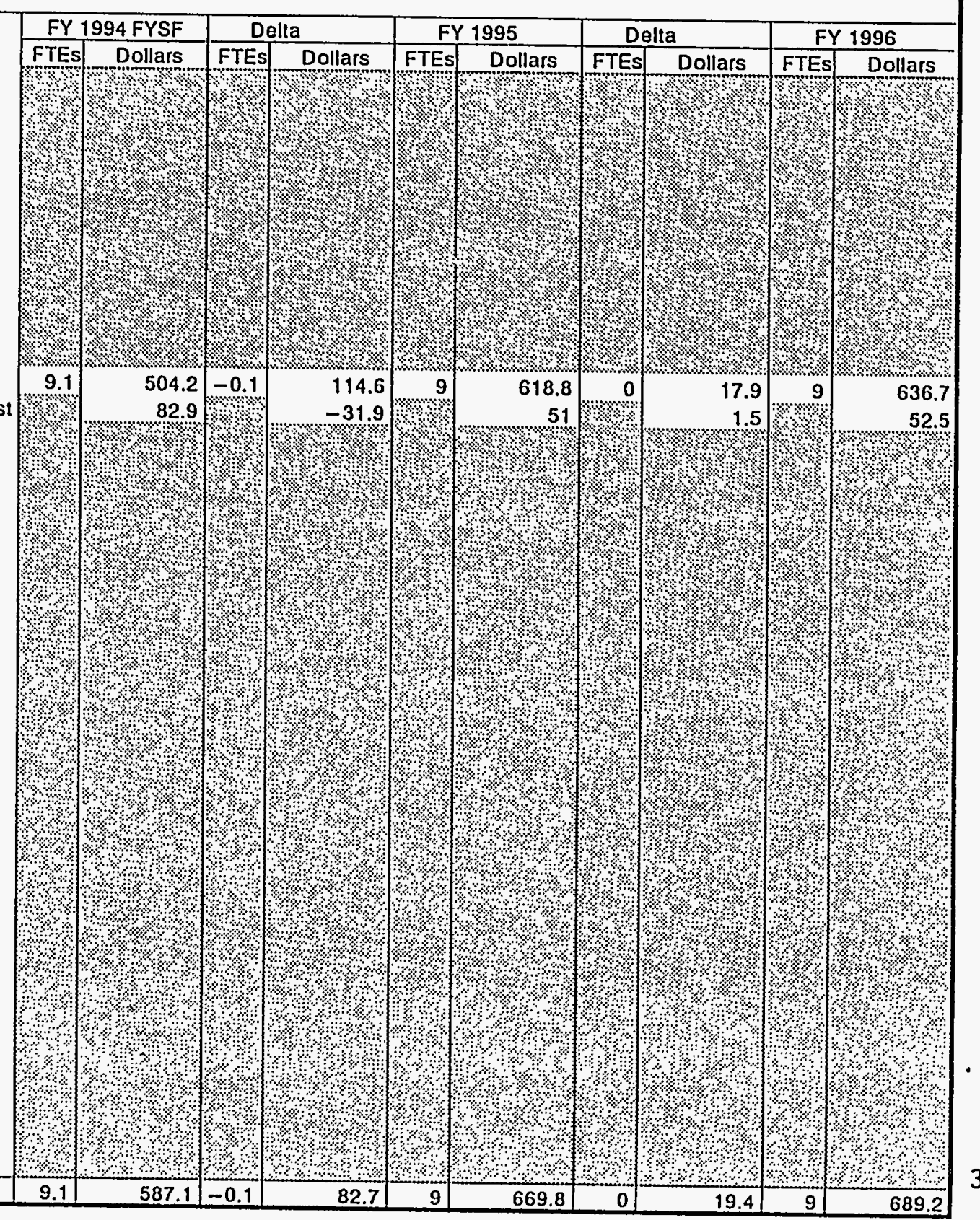

Labor Cost

Non-Labor Cost 


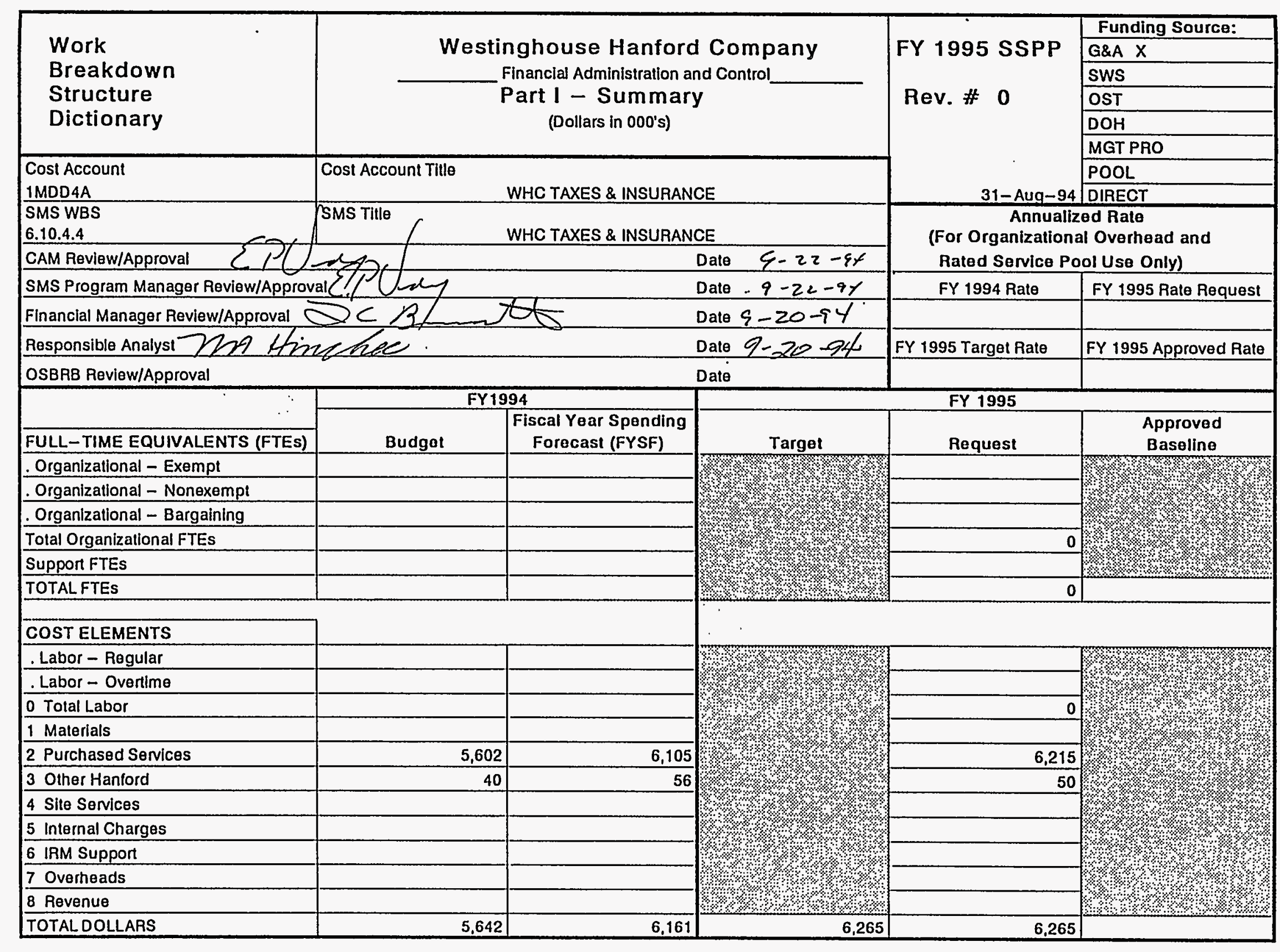




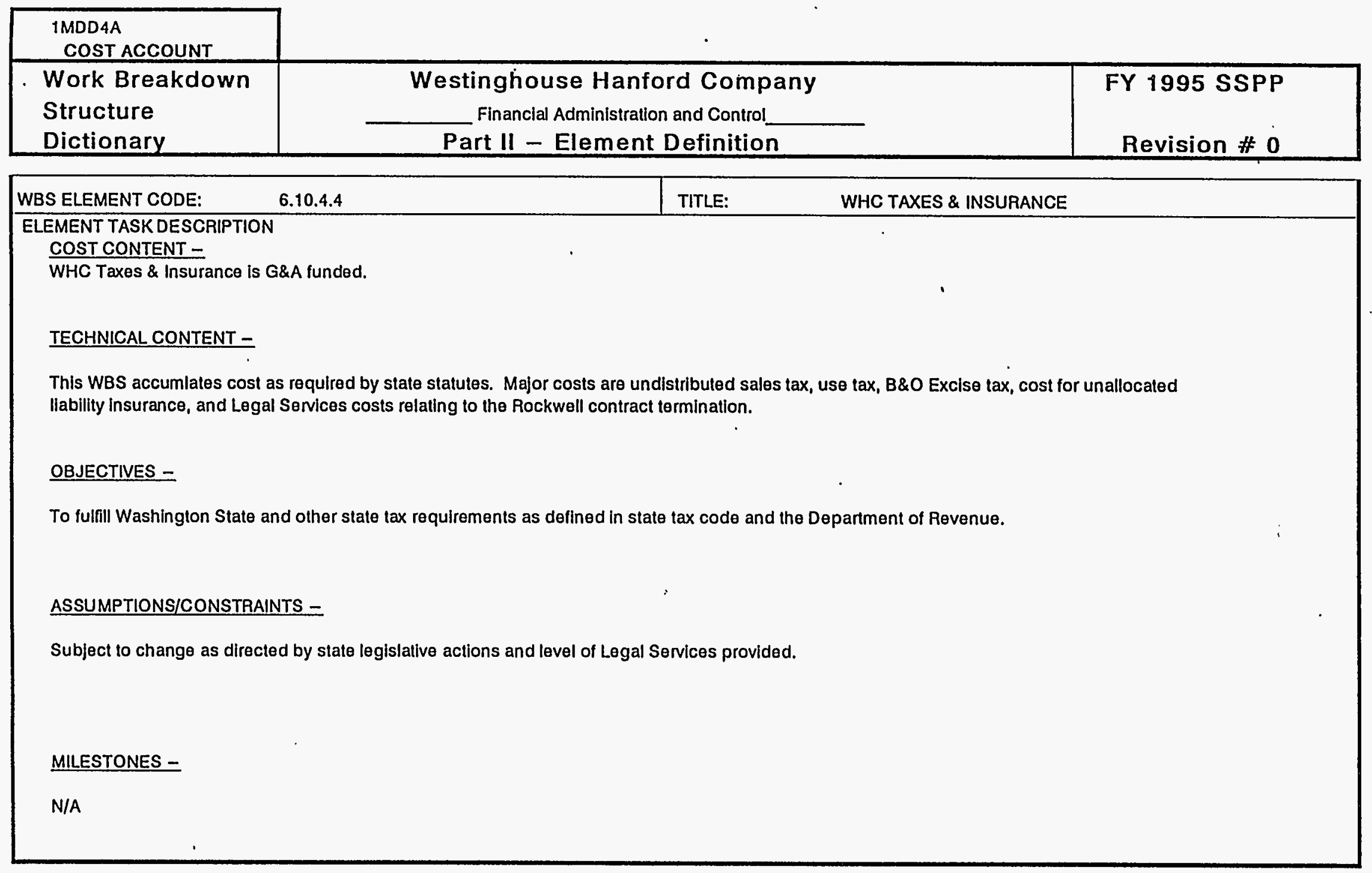




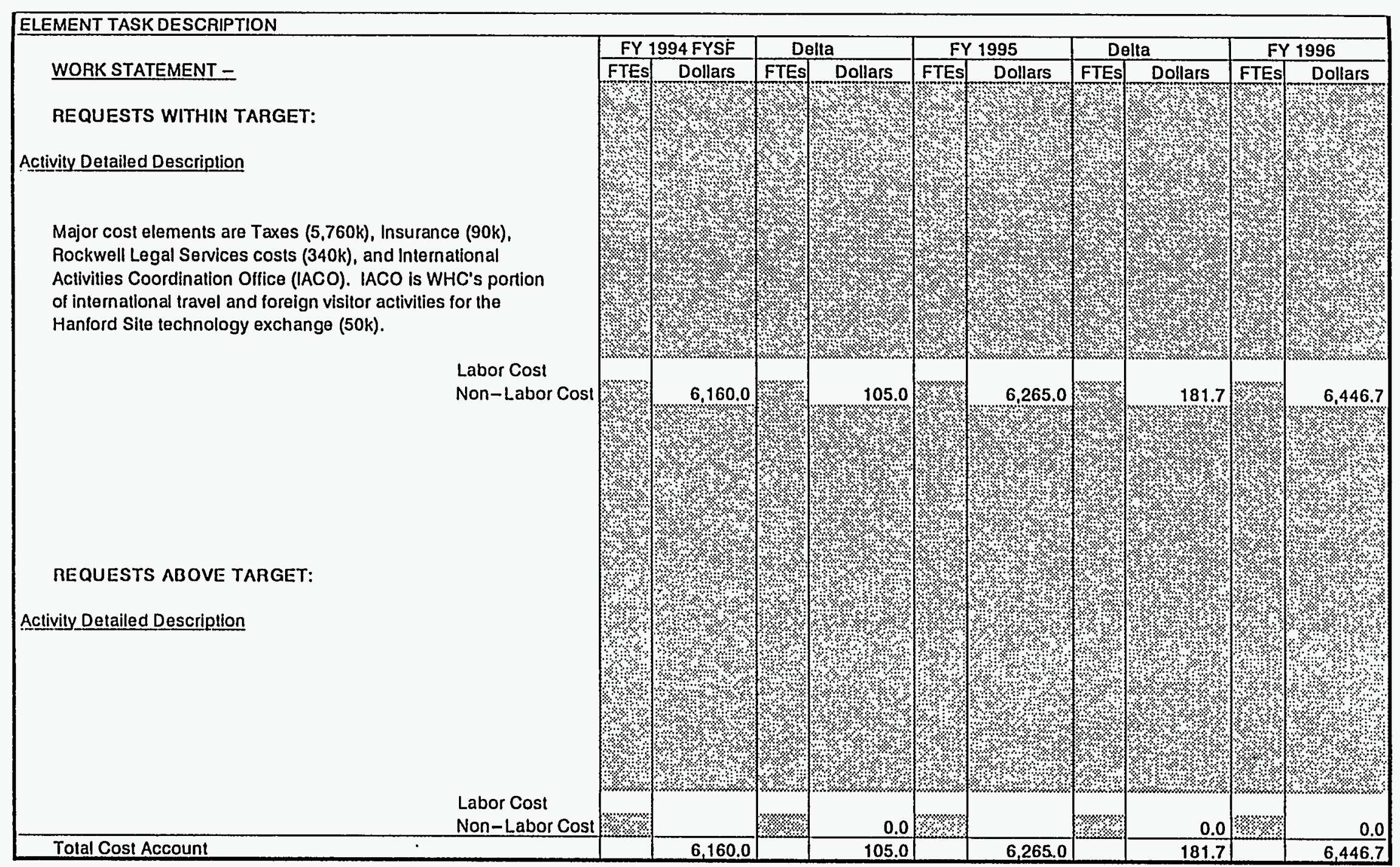




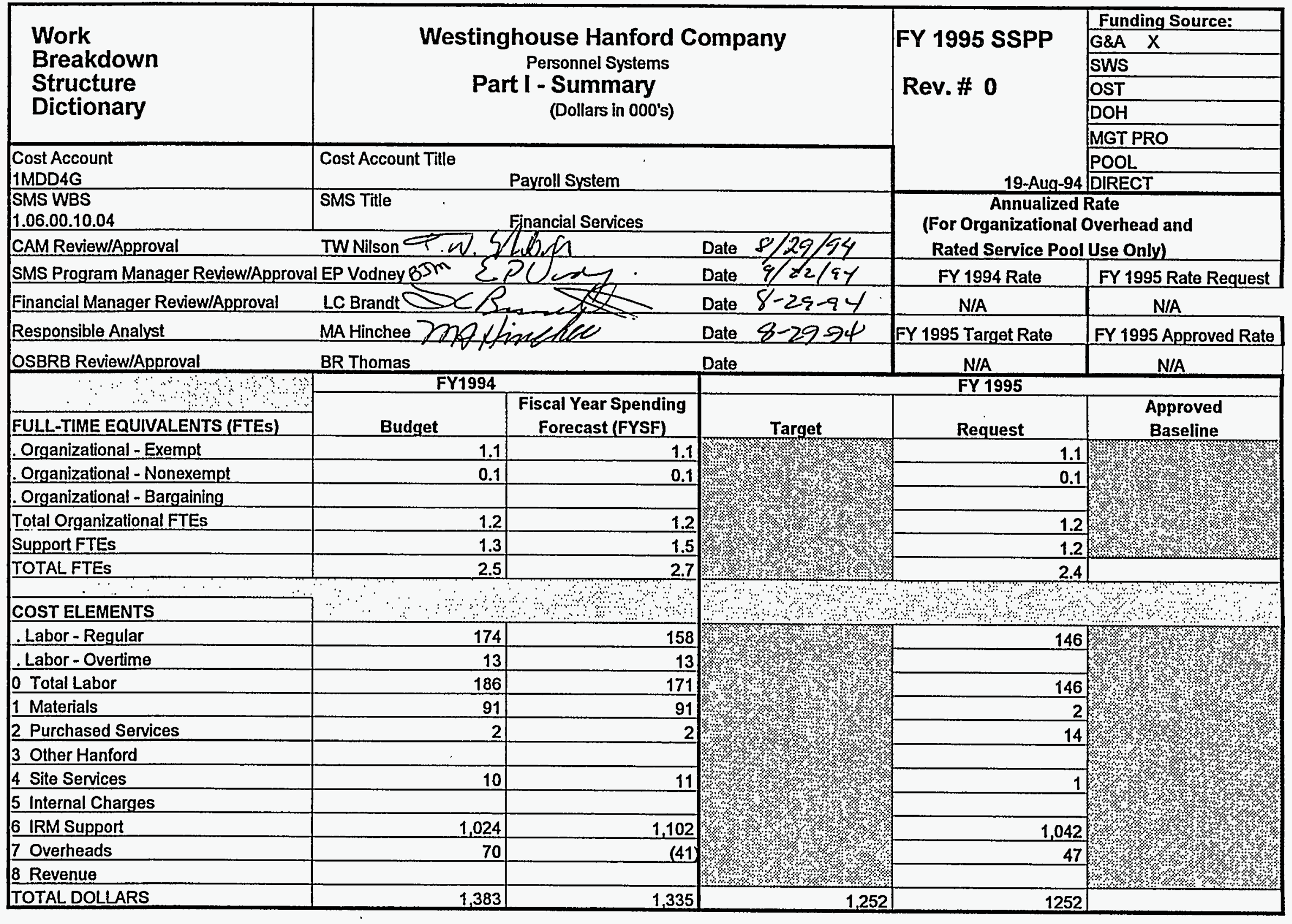




\begin{tabular}{|l|c|c|}
\hline \multicolumn{1}{|c|}{ cosT AccounT } & \multicolumn{2}{|c|}{ FY 1995 SSPP } \\
\hline $\begin{array}{l}\text { Work Breakdown } \\
\text { Structure } \\
\text { Dictionary }\end{array}$ & Westinghouse Hanford Company & Personnel Systems \\
\hline
\end{tabular}

\begin{tabular}{|l|l|}
\hline WBS ELEMENT CODE: 1.06 .00 .10 .04 & TITLE: Financial Services \\
\hline ELEMENT TASK DESCRIPTION &
\end{tabular}
COST CONTENT -
source for this element in FY 1995 is G\&A. Budget target from 1MDD4D is $\$ 1179.7 \mathrm{~K}$ and from $1 \mathrm{MDD} 17$ is $\$ 72.6 \mathrm{~K}$.

IECHNICAL CONTENT - This element funds the operation, maintenance and enhancement of the Westinghouse Human Resource system (WHR). WHR is currently a comprehensive system that supports both the Westinghouse Hanford Company (WHC) Payroll and Human Resources organizations. However, with the implementation of a new integrated human resource system by the end of FY 1994 , WHR will support only the Payroll organization in FY 1995 and FY 1996.

The majority of these funds pay for internal senices from BCS Richland Inc. (BCSR) - primarily labor and central computer operations. These funds also cover WHC Personnel Systems labor (providing systems analysis, management and clerical support), purchased materials, computer hardware/software, and services necessary to support the the payroll system.

The primary WHC manuals that this work is to comply with are Software Practices (CM-3-10), Data Administration Standards (CM-2-6), and Management Requirements and Procedures (CM-1-3). These WHC manauals are based on several Department of Energy (DOE) Orders that are referenced within them. Also, the payroll function supported by the system has its own regulatory drivers, which often carry over into requirements that must be met by the system.

OBJECTIVES Provide a stable, cost-effective system that meets customer requirements and is in compliance with regulatory drivers.

\section{ASSUMPTIONSICONSTRAINTS -}

Minimal staffing change in the Personnel Systems organization. Adequate staffing levels within BCSR (or outsourced staff). Labor rates and adders consistent with those provided on June 28,1994 , as the FY 1995 planning rates. BCSR central facility computing rates in FY 1995 are reduced from the FY 1994 rates, consistent with the level of FY 1994 passback of central facility computing over-liquidations. Escalation rates per June 15, 1994 Controller guidance.

MILESTONES -

Routine milestones such as completing weekly and bi-weekly payroll processings and accomplishing calendar year-end payroll processing activities.

DELIVERABLES -

Source code, system design documentation, and functional specifications associated with system changes. 


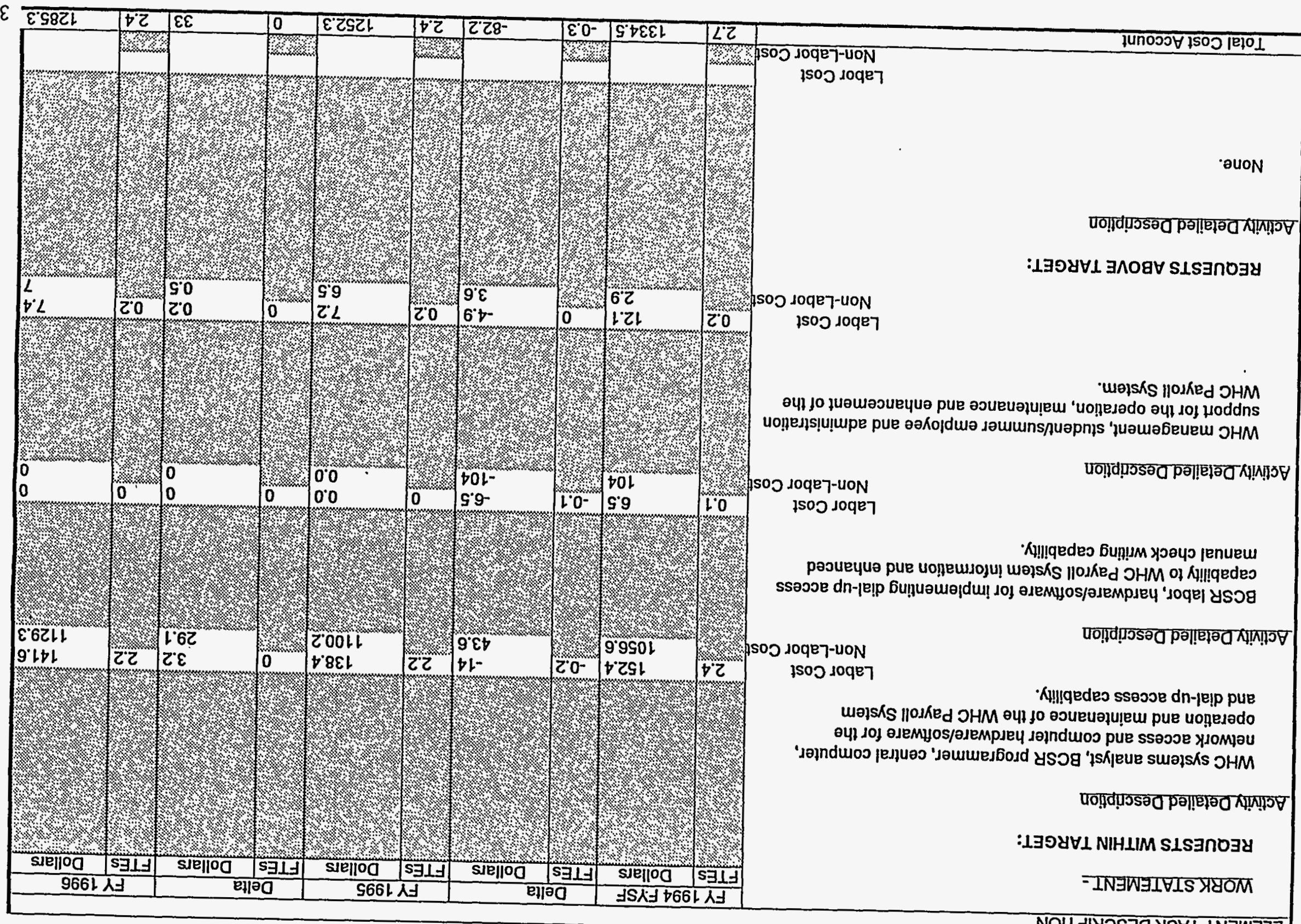

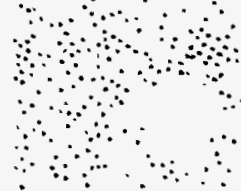




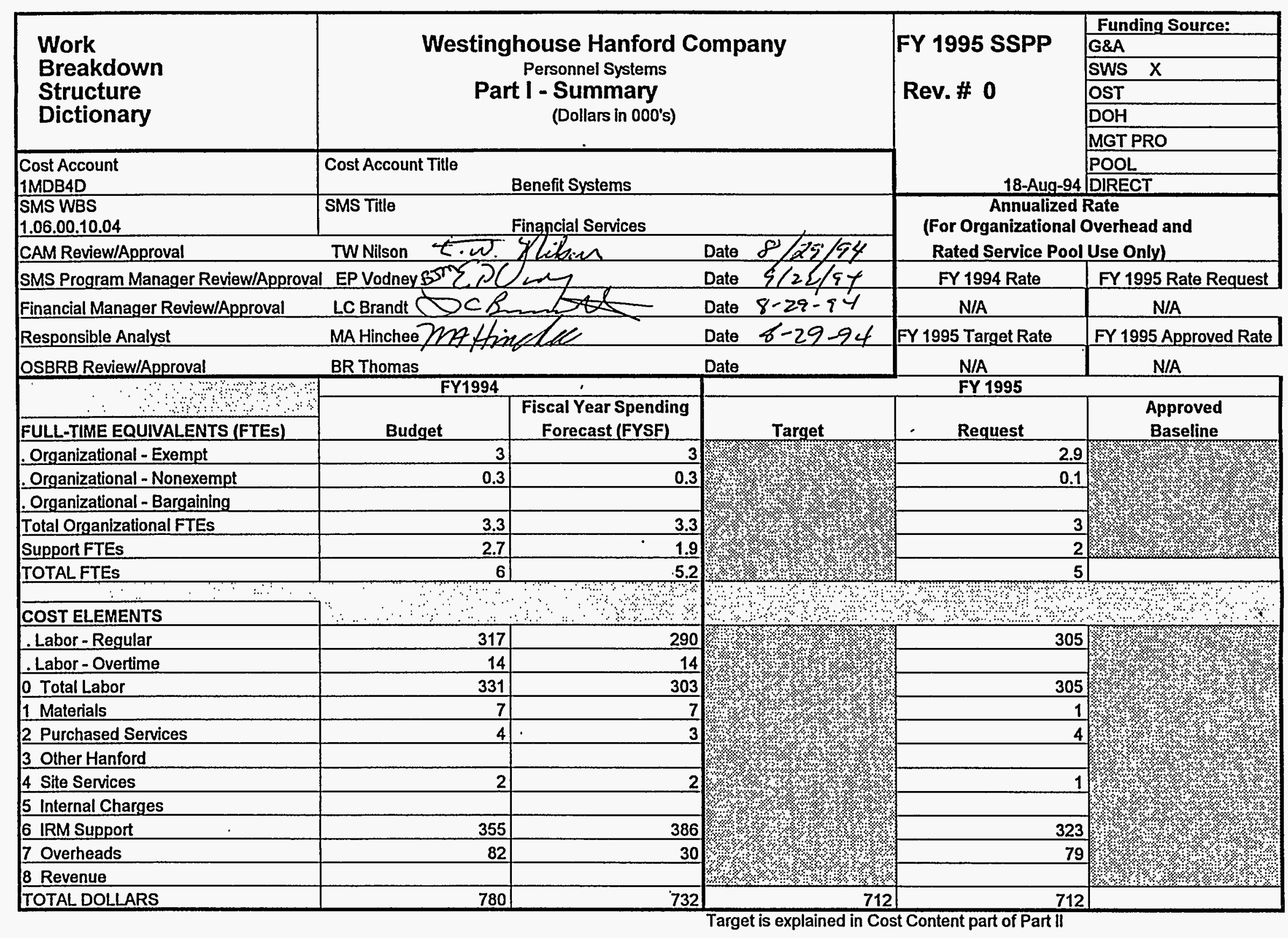


COST ACCOUNT

\section{Work Breakdown}

Structure

Dictionary

\section{Westinghouse Hanford Company}

Personnel Systems

Part II - Element Definition

FY 1995 SSPP

\begin{tabular}{|l|l} 
WBS ELEMENT CODE: 1.06 .00 .10 .04 & TITLE: Financial Services \\
\hline
\end{tabular}

ELEMENT TASK DESCRIPTION

COST CONTENT -

This element was included in the General and Administrative (G\&A) cost accounts 1MDD4D and 1MDD17 in FY 1994. These G\&A cost accounts only represented the Westinghouse Hanford Company (WHC) portion of the costs. The fund source for this element in FY 1995 is Site Wide Support (SWS) and will be split $93 \%$ to WHC, 2\% to PNL and 5\% to BHI. This SWS Cost account reflects total cost. Budget target of $\$ 711.9 \mathrm{~K}$ comes from 1MDD4D (\$493.3K), 1MDD17 (\$168.7K), 1MDD4E (\$7.0K), and 1MDBHI (\$42.9K).

IECHNICAL CONTENT - This element funds the operation and maintenance of the WHC benefit systems, which include the Site-Wide-Savings (SWS), Hanford Pension Plan (HPP), and Retiree Information (RIS) systems. Customers for these systems are in the Penson and Savings investments organization, which administer the savings, pension and insurance plans for all WHC, BCS Richland, Inc. (BCSR), ICF Kaiser, and Bechtel Hanford employees and Pacific Northwest Labratory (PNL) Hanford Atomic Metal Trades Council (HAMTC) employees.

The majority of these funds pay for internal services from BCSR - primarily labor and central computer operations. These funds also cover WHC Personnel Systems systems analyst , management and clerical labor, purchased materials, and services necessary to support the benefit systems.

The primary WHC manuals that this work is to comply with are Software Practices (CM-3-10), Data Administration Standards (CM-2-6), and Management Requirements and Procedures (CM-1-3). These WHC manuals are based on several Department of Energy (DOE) Orders that are referenced within them. Also, the benefits function supported by the systems has its own regulatory drivers, which often carry over into requirements that must be met by the systems.

OBJECTIVES - $\quad$ Provide stable, cost-effective systems that meet customer requirements and are in compliance with regulatory drivers.

\section{ASSUMPTIONS/CONSTRAINTS-}

Minimal staffing change in the Personnel Systems organization. Adequate staffing levels within BCSR (or outsourced staff). Labor rates and adders consistent with those provided on June 28,1994 , as the FY 1995 planning rates. BCSR central facility computing rates in FY 1995 are reduced from the FY 1994 rates, consistent with the level of FY1994 passback of central facility computing over-liquidations. Escalation rates per June 15, 1994 Controller guidence.

MILESTONES -

Potentially, providing support to special retirement and separation offerings. Routine milestones such as completing weekly and monthly processing.

DELIVERABLES - Source code, system design documentation, and functional specifications associated with system changes. 


\begin{tabular}{|c|c|c|c|c|c|}
\hline \multirow{5}{*}{$\begin{array}{l}\text { Work } \\
\text { Breakdown } \\
\text { Structure } \\
\text { Dictionary }\end{array}$} & \multirow{5}{*}{\multicolumn{3}{|c|}{$\begin{array}{c}\text { Westinghouse Hanford Company } \\
\text { Financlal Systems } \\
\text { Part I - Summary } \\
\text { (Dollars in 000's) }\end{array}$}} & \multirow{7}{*}{$\begin{array}{l}\text { FY } 1995 \text { SSPP } \\
\text { Rev. \# } 0\end{array}$} & \multirow{3}{*}{$\begin{array}{l}\text { Funding Source: } \\
\text { G\&A X } \\
\text { SWS } \\
\end{array}$} \\
\hline & & & & & \\
\hline & & & & & \\
\hline & & & & & OST \\
\hline & & & & & $\mathrm{DOH}$ \\
\hline Cost Account & Cost Account Tille & & & & $\begin{array}{l}\text { POOL } \\
\end{array}$ \\
\hline IMDDAK & Financial Systems & & & & DIRECT \\
\hline $\begin{array}{l}\text { SMS WBS } \\
1.06 .00 .10 .04 \\
\end{array}$ & $\begin{array}{l}\text { SMS Title } \\
\text { Financial Services }\end{array}$ & & & $\begin{array}{r}\text { Annualize } \\
\text { (For Organizational }\end{array}$ & al Overhead and \\
\hline CAM Review/Approval & S.L. Koreis Del & eses & Date \&/29 & Rated Service Poc & ol Use Onty) \\
\hline SMS Program Manager Revlew/Approva & al E.P. VodneyBsm & & Date & FY 1994 Rate & FY 1995 Rate Request \\
\hline Financial Manager Revlew/Approval & L.C. BrandLDC\& & 44 & Date $8-29-9 y$ & & \\
\hline Responsible Analyst & M.A. Hincheo $D$ FAL & & Date $8>9-94$ & FY 1995 Target Rate & FY 1995 Approved Rate \\
\hline OSBRB Review/Approval & B.R. Thomas & & Date & & \\
\hline ,,$y^{\prime}$ & FY19: & & & FY 1995 & \\
\hline FULL-TIME EQUIVALENTS (FTES) & Budget & \begin{tabular}{|c|} 
Fiscal Year Spending \\
Forecast (FYSF)
\end{tabular} & Target & Request & $\begin{array}{l}\text { Approved } \\
\text { Baseline }\end{array}$ \\
\hline . Organizational - Exempt & 11 & 11 & & 11 & ২. \\
\hline . Organizational - Nonexempt & 1 & 1 & 1 & 1 & \\
\hline Organizational - Bargaining & 0 & 0 & 18. & 0 & \\
\hline Tolal Organizational FTEs & 12 & 12 & \$14. & 12 & \\
\hline Support FTEs & 14 & 13 & & 15.8 & $8 \%$ \\
\hline TOTALFTES & 26 & 25 & 5 & 27.8 & \\
\hline$\frac{\therefore}{1 \text { COSTELEMENTS }}$ & $\because \because:$ & $\because$ & נo & 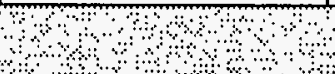 & म্য \\
\hline Labor - Regular & 1,627 & 1,453 & & 1,714 & \\
\hline Labor - Overtime & 46 & 71 & & 55 & \\
\hline 0 Total Labor & 1,581 & 1,524 & & 1,769 & \\
\hline 1 Materials & 262 & 190 & & 193 & \\
\hline 2 Purchased Services & 211 & 144 & & 105 & \\
\hline 3 Other Hanford & 0 & 1 & $17 \%$ & 1 & \\
\hline 4 Site Services & 40 & 22 & & 25 & \\
\hline 5 Internal Charges & 0 & 0 & ? & 0 & \\
\hline 6 IRM Support & 2,777 & 3,596 & & 3,619 & \\
\hline 7 Overheads & 562 & 494 & & 634 & \\
\hline 8 Revenue & 0 & 0 & 210 & 0 & $140 \%$ \\
\hline TOTALDOLLARS & 5,528 & 5,971 & 6,344 & 6,344 & \\
\hline
\end{tabular}




\section{CosT ACcoUNT Work Breakdown Structure Dictionary}

\section{Westinghouse Hanford Company \\ Financial Systems \\ Part II - Element Definition}

FY 1995 SSPP

Revision \# 0

\begin{tabular}{l|l|}
\hline WBS ELEMENT CODE: $\quad 1.06 .00 .10 .04$ & TITLE: \\
\hline ELEMENT TASK DESCRIPTION \\
COST CONTENT \\
IMDD4F and 1MDD17. The FY fund source for this element is General and Administrative (G\&A). In FY 1994, this element was included in cost accounts
\end{tabular}

MDD4F and 1MDD17. The FY 1995 budget target from 1 MDD4F is $\$ 5,635.9 \mathrm{~K}$ and from 1 MOD17 is $\$ 707.8 \mathrm{~K}$

IECHNICAL CONTENT This element funds the operation, maintenance, enhancement and development of systems used to control and/or administer Westinghouse Hanford Company (WHC) financial assets, and/or are used for business planning and management. Direct customers for these systems are in the Controller organization, however program managers, cost account managers, and non-Controller financial managers are strong indirect customers for these systems.

The majority of these funds pay for Internal services from BCS Richland, Inc. (BCSR) - primarily labor and central facillty computer operations. The labor is primarily from the Information and Scientific Systems (ISS) organization within BCSR. These funds also cover the purchased materials and services necessary to support the financial systems; plus organizational labor costs for management, systems analysls, and secretarial support, and associated costs for basic service and materlal.

The primary WHC manuals this work is to comply with are Software Practices (CM-3-10), Data Adminlstration Standards (CM-2-6), and Management Requirements and Procedures (CM-1-3). These WHC manuals are based on several Department of Energy (DOE) orders referenced within them. Also the business functlons supported by the financial systems have their own regulatory drivers, which often carry over into requirements that must be met by the automated systems.

OBJECTNES Provide stable, cost effective systems that meet customer requirements and are in compliance with regulatory drivers.

ASSUMPTIONS/CONSTRAINTS Minimal staffing change In the Financial Systems organization. Adequate support staffing levels within BCSR (or outsourced stafi Labor rates and adders consistent wilh those provided on June 28, 1994, es the FY1995 planning rates. BCSR central facility computing rates in FY 1995 are reduced from the FY 1994 rates, consistent with the level of FY 1994 passback of central faciltiy computing over-liquldatlons. Escalation rates per June 15, 1994, Controller guidance. BCSR will have TCP/IP telecommunications technology implemented as required to support applicable projects.

\section{MILESTONES}

Financial system integration briefing - 11/1/94, Complete the integration of the ICF KH and WHC/BCSR financlal systems - 11/5/94, Reflect, in financlal system's performance reports, the capablity of having multiple performing organizalions - 11/5/94, Prepare plan for financlal business requirements to be met via automation - 12/15/94, Implement first function release of the Time Information System (TIS) - 12/30/94, Implement Operations Travel System (OTS) gateway use by a small number of high volume users - 2/1/95, Implement MARS/SGL phase II -2/28/95, Expand the financlal system's purge process and modity master (MODMAST) process to include Kaiser Project Control Numbers (KPCN's) - 8/1/95, TIS implemented for all WHC/ICF KH/BCSR organizations - 9/30/95

\section{DELNERABLES}

Source code, system design documentation and functlonal specifications associated with system changes. Presentation package for finanical systems integration brlefing. Plan documentation for determining financlal business requirements. 


\section{Part II - Element Definition (continued)}

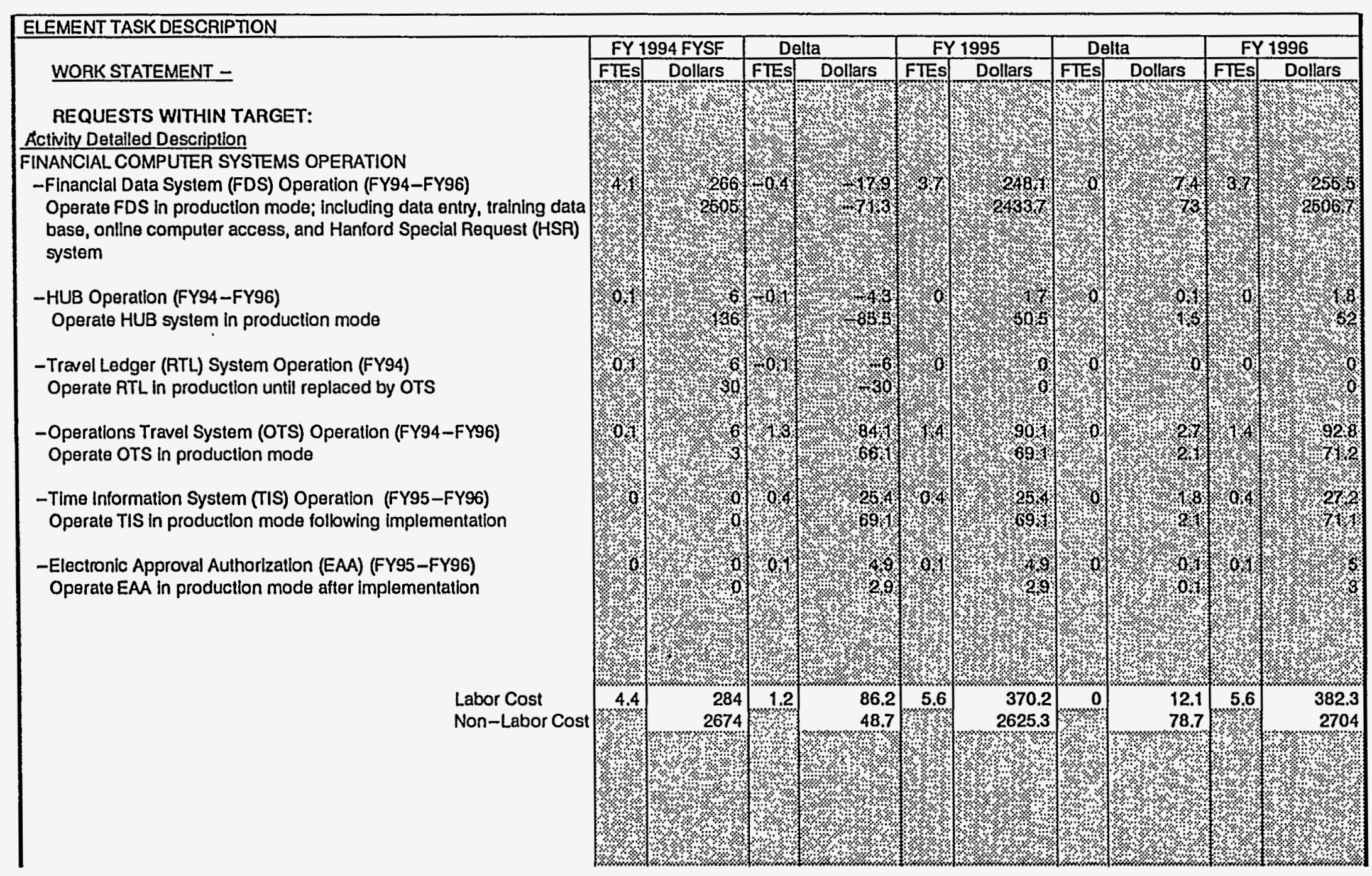




\section{Cost Account}

Part II - Element Definition (continued)

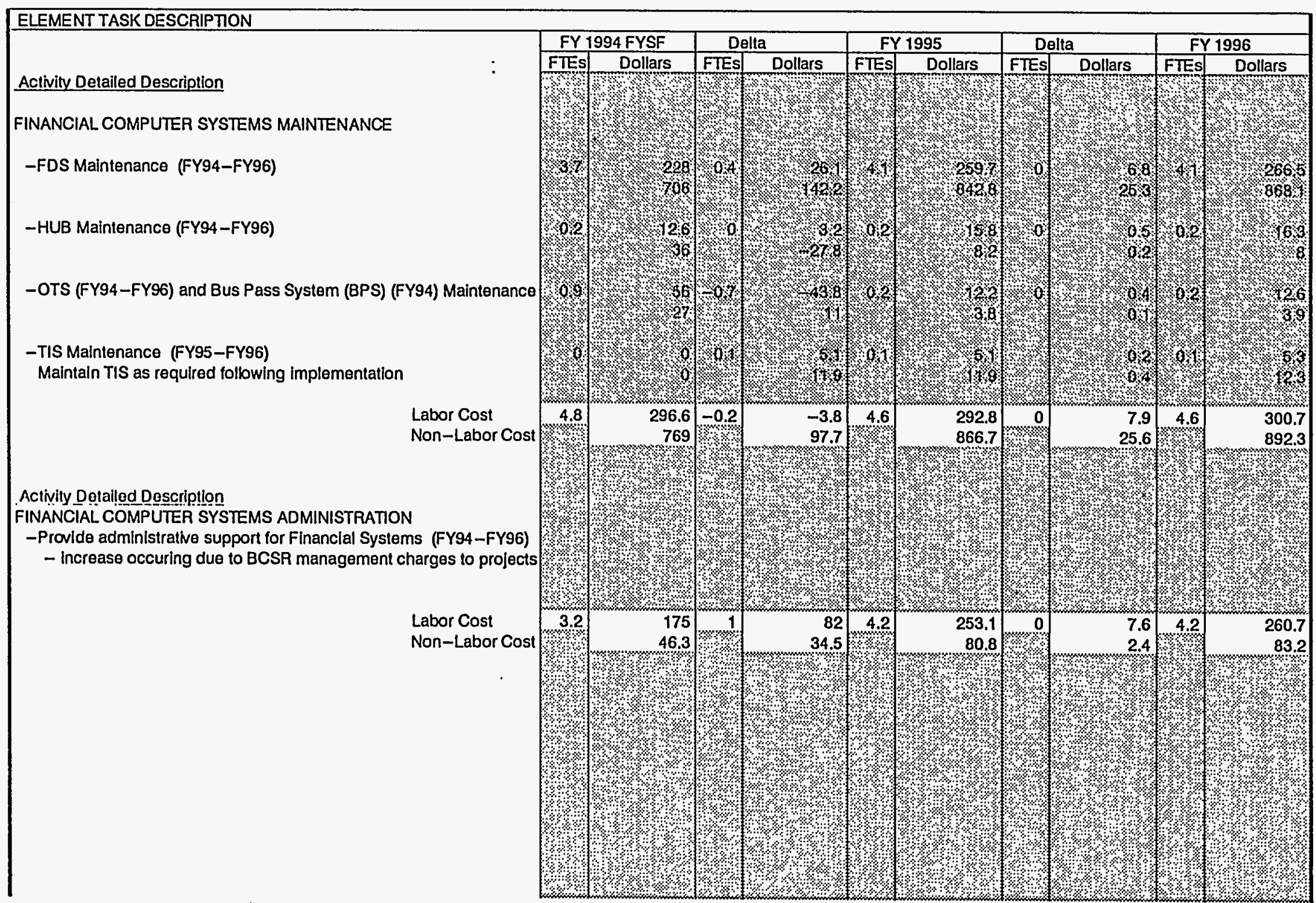




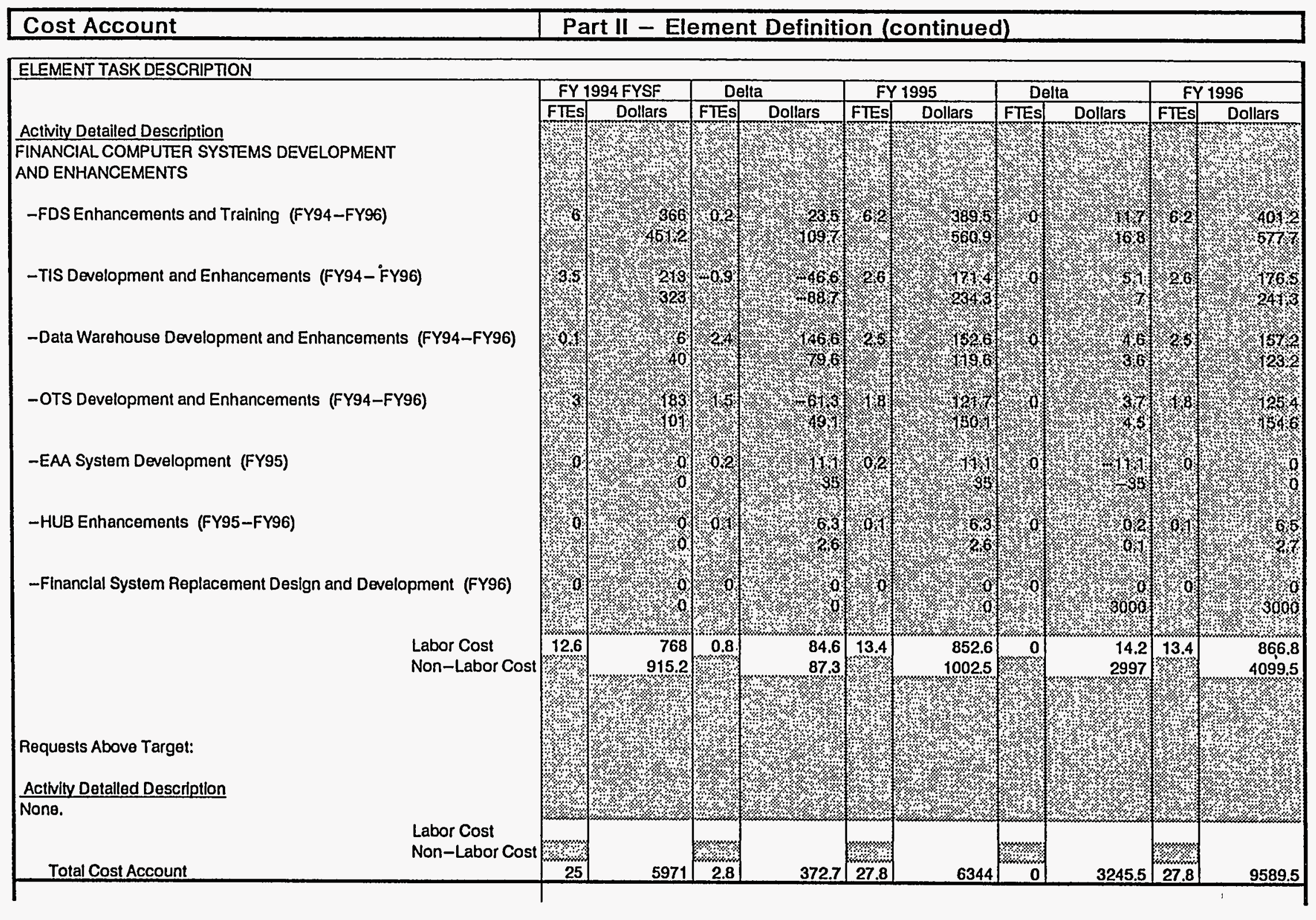




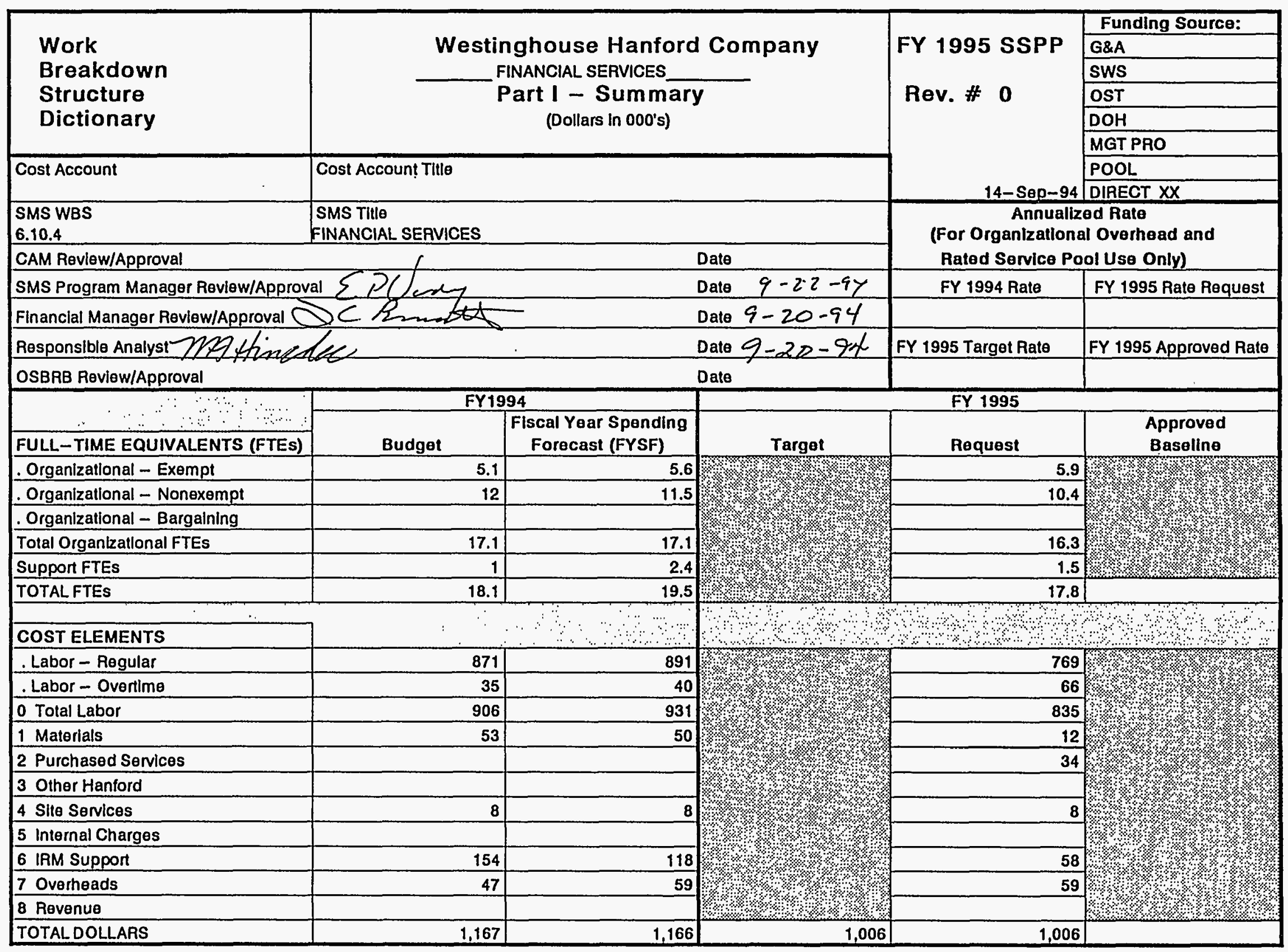




\begin{tabular}{|l|c|c|}
\hline \multicolumn{1}{|c|}{ CosT ACcounT } & \multicolumn{2}{|c|}{} \\
\hline $\begin{array}{l}\text { Work Breakdown } \\
\text { Structure } \\
\text { Dictionary }\end{array}$ & Westinghouse Hanford Company & FY 1995 SSPP \\
\cline { 2 - 3 } & FINANCIAL ADMINISTRATION \& CONTROL & Revision \# 0 \\
\hline
\end{tabular}

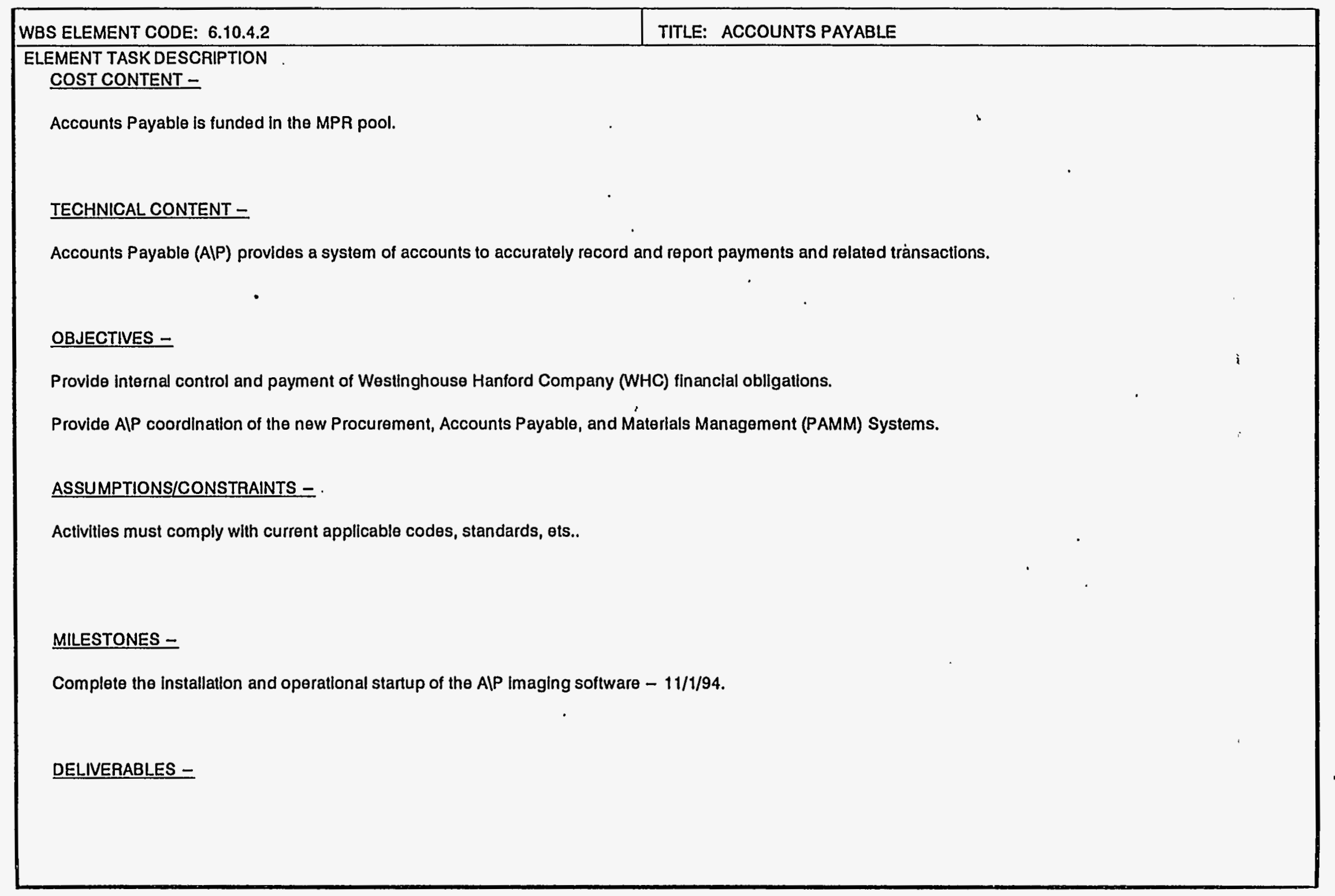




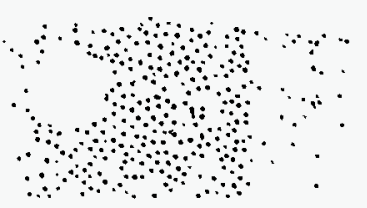

Cost Account

Part II - Element Definition (continued)

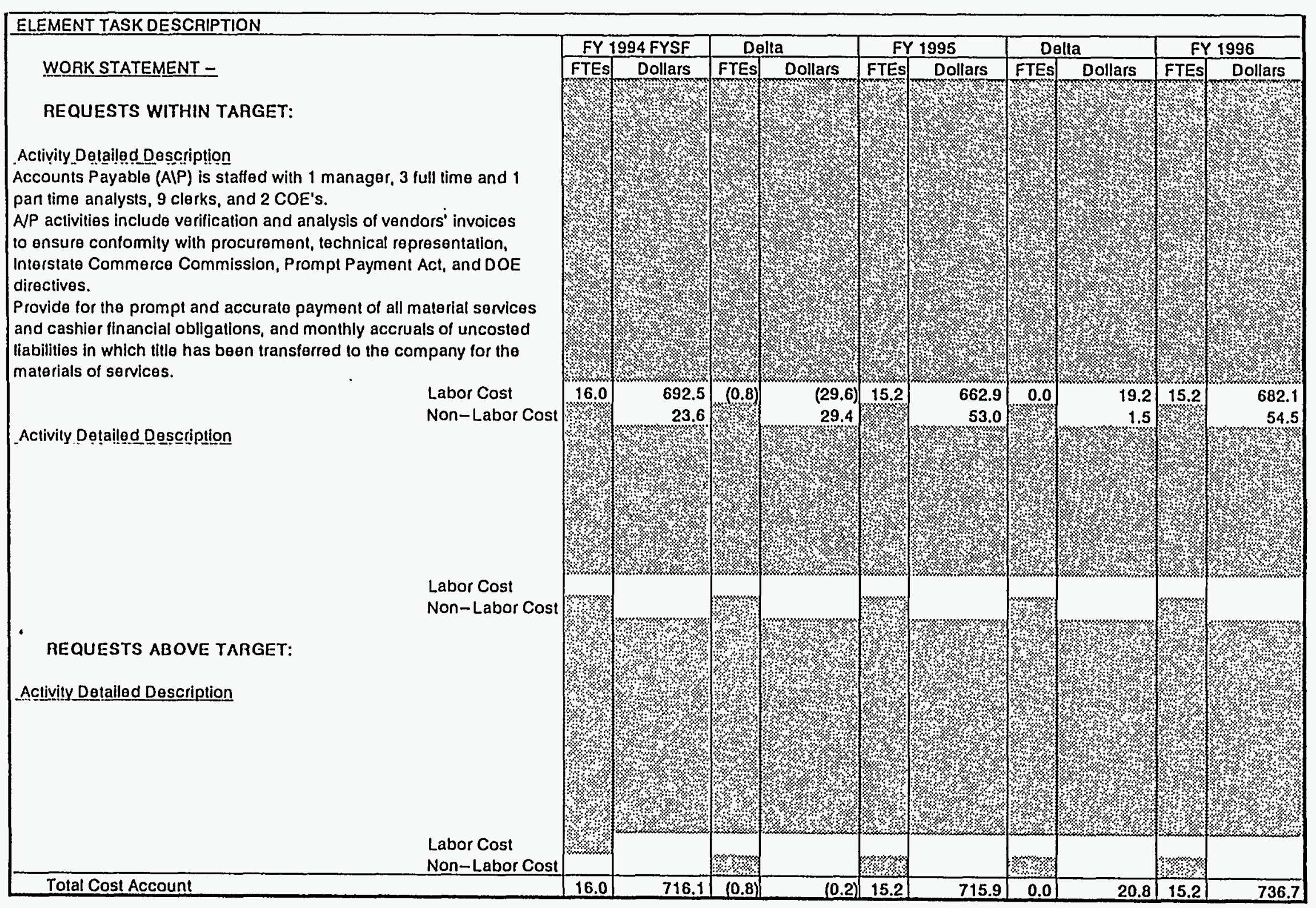




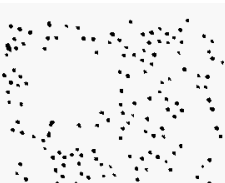

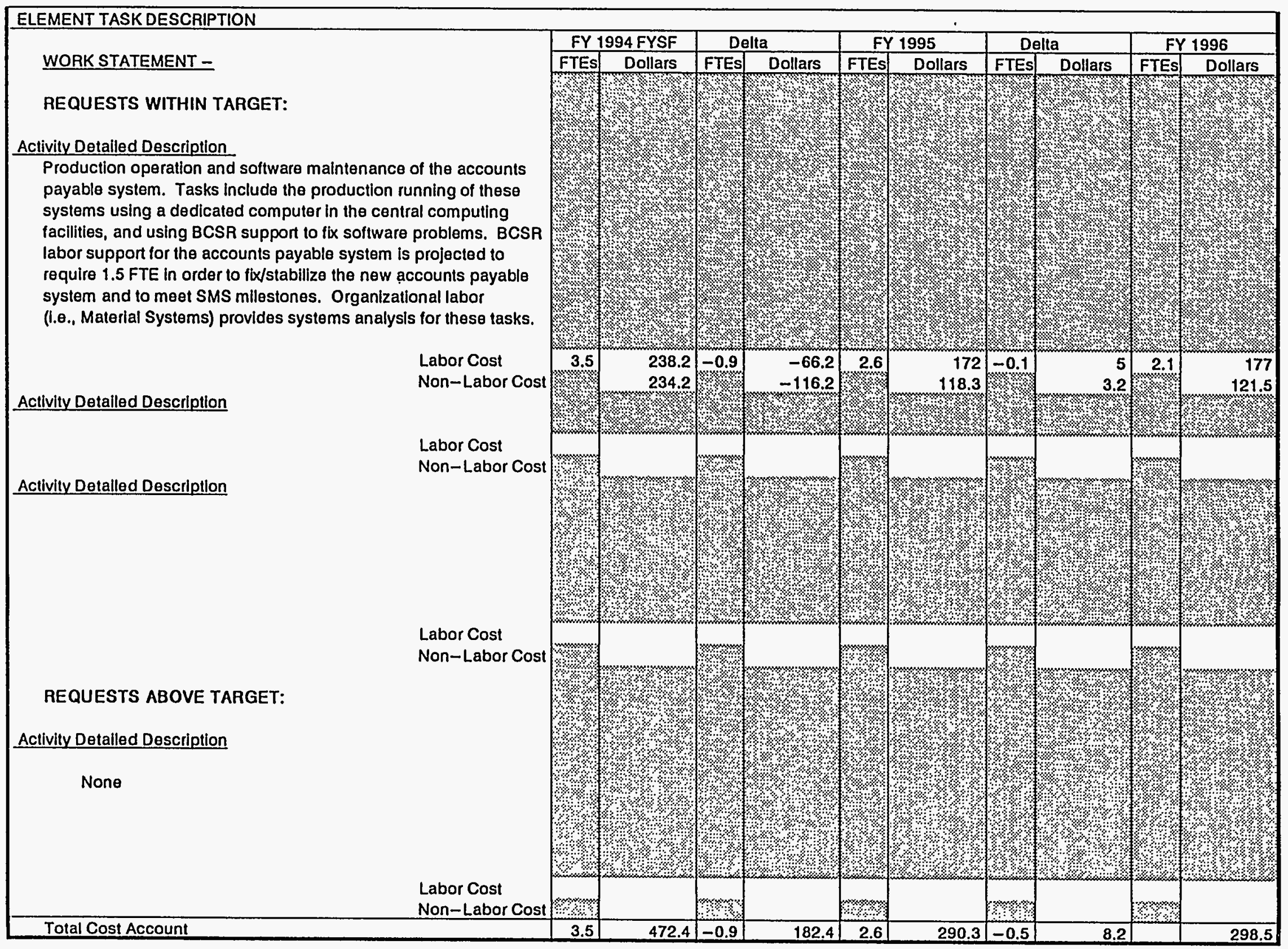


3.B WBS Milestone Description Sheet
Hestinghouse Hanford Company

Finance and Administration

WBS 6.10

FY 1995 SSPP

FINANCIAL SERVICES

WBS 6.10 .4

\section{Westinghouse Hanford Company MILESTONE DESCRIPTION SHEET}

\begin{tabular}{|c|c|c|c|}
\hline \multicolumn{3}{|c|}{ Title: Cost Savings Initiatives Update } & Date: $08 / 31 / 94$ \\
\hline \multicolumn{3}{|c|}{ Assigned To: Financial Administration } & CIN: \\
\hline \multicolumn{3}{|c|}{ Program WBS Designator: 6.10 .4 .1} & $\begin{array}{l}\text { Due Date: Monthly } \\
(10 / 94-9 / 95)\end{array}$ \\
\hline \multicolumn{3}{|c|}{ Control Number: FFS-95-001 through FFS-95-012 } & Revision: \\
\hline 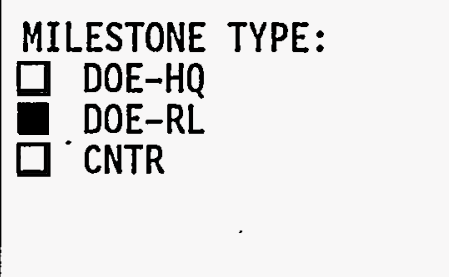 & \begin{tabular}{ll}
\multicolumn{1}{c}{ DIVISION: } \\
$\square$ State \\
$\square$ Federal \\
$\square$ DOE \\
$\square$ RCRA \\
$\square$ TPA\# \\
\end{tabular} & $\begin{array}{ll} & \text { DELIVERABLE: } \\
\text { Report } \\
\square \text { Letter } \\
\square \text { Drawings } \\
\square \text { Other (specify) }\end{array}$ & $\begin{array}{ll} & \text { ADDRESS TO: } \\
\square & \text { DOE-HQ } \\
\text { DOE-RL } \\
\square \text { Other (specify) }\end{array}$ \\
\hline \multicolumn{4}{|c|}{ Milestone Description } \\
\hline \multicolumn{4}{|c|}{ Deliver monthly status to. RL regarding Financial Services cost savings initiatives. } \\
\hline \multicolumn{4}{|c|}{ Description of what constitutes completion of this milestone: } \\
\hline \multicolumn{4}{|c|}{$\begin{array}{l}\text { Apprise RL monthly of the status of ongoing Financial Services cost savings } \\
\text { initiatives, including progress, findings, and results. }\end{array}$} \\
\hline \multicolumn{2}{|l|}{ Cost Account Manager } & \multicolumn{2}{|c|}{ Program/Project Manager Date } \\
\hline \multicolumn{2}{|c|}{ Program Element Manager Date } & \multicolumn{2}{|c|}{ DOE Monitor Date } \\
\hline
\end{tabular}




\section{B WBS Milestone Description Sheet}

Hestinghouse Hanford Company

Finance and Administration

HBS 6.10

FINANCIAL SERVICES

HBS 6.10 .4

\section{Westinghouse Hanford Company MILESTONE DESCRIPTION SHEET}

\begin{tabular}{|c|c|c|c|}
\hline Title: Provide Perfo & rmance Self-Evalu & nput & Date: $08 / 31 / 94$ \\
\hline Assigned To: Financi & al Administration & & CIN: \\
\hline Program WBS Designato & $r: \quad 6.10 .4 .1$ & & $\begin{array}{l}\text { Due Date: } 10 / 5 / 94 \\
\text { and } 4 / 6 / 95\end{array}$ \\
\hline Control Number: FFS- & $95-013$ and FFS -95 & & Revision: \\
\hline $\begin{array}{l}\text { MILESTONE TYPE: } \\
\square \text { DOE-HQ } \\
\text { DOE-RL } \\
\square \text { CNTR }\end{array}$ & \begin{tabular}{ll}
\multicolumn{1}{c}{ DIVISION: } \\
$\square$ State \\
$\square$ Federal \\
$\square$ & DOE \\
$\square$ & RCRA \\
$\square$ & TPA\# \\
\end{tabular} & $\begin{array}{ll} & \text { DELIVERABLE: } \\
& \text { Report } \\
\square & \text { Letter } \\
\square & \text { Drawings } \\
\square & \text { Other (specify) }\end{array}$ & $\begin{array}{ll} & \text { ADDRESS TO: } \\
\square & \text { DOE-HQ } \\
\text { DOE-RL } \\
\square \text { Other (specify) }\end{array}$ \\
\hline Milestone Descriptio & & & \\
\hline $\begin{array}{l}\text { Provide a Performance } \\
\text { Control's performance }\end{array}$ & $\begin{array}{l}\text { Self-Evaluation } \\
\text { based on the pre }\end{array}$ & $\begin{array}{l}\text { escribes Financial } \\
\text { six-month period. }\end{array}$ & nistration and \\
\hline Description of what $c$ & onstitutes comple & this milestone: & \\
\hline $\begin{array}{l}\text { Provide input into th } \\
\text { RL. }\end{array}$ & e company overall & rmance Self-Evaluati & which is provided to \\
\hline Cost Account Manager & Date & Program/Project Man & Date \\
\hline Program Element Manag & Date & DOE Monitor & Date \\
\hline
\end{tabular}


3.B HBS Milestone Description Sheet
Westinghouse Hanford Company

Finance and Administration

WBS 6.10

FY 1995 SSPP

FINANCIAL SERVICES

WBS 6.10 .4

\section{Westinghouse Hanford Company \\ MILESTONE DESCRIPTION SHEET}

\begin{tabular}{|c|c|c|c|}
\hline \multicolumn{3}{|c|}{ Title: Performance Measures } & Date: $08 / 31 / 94$ \\
\hline \multicolumn{3}{|c|}{ Assigned To: Financial Administration } & CIN: \\
\hline \multicolumn{3}{|c|}{ Program WBS Designator: 6.10.4.1 } & Due Date: $12 / 30 / 94$ \\
\hline \multicolumn{3}{|c|}{ Control Number: FFS-95-015 } & Revision: \\
\hline $\begin{array}{l}\text { MILESTONE TYPE: } \\
\square \text { DOE-HQ } \\
\text { DOE-RL } \\
\square \text { CNTR }\end{array}$ & \begin{tabular}{ll} 
& \multicolumn{1}{c}{ DIVISION: } \\
$\square$ & State \\
$\square$ & Federa7 \\
DOE \\
DOE \\
$\square$ RCRA \\
$\square$ TPA\#
\end{tabular} & $\begin{array}{ll} & \text { DELIVERABLE: } \\
& \text { Report } \\
& \text { Letter } \\
\square & \text { Drawings } \\
\square \text { Other (specify) }\end{array}$ & $\begin{array}{ll} & \text { ADDRESS TO: } \\
\square & \text { DOE-HQ } \\
\text { DOE-RL } \\
\square \text { Other (specify) }\end{array}$ \\
\hline
\end{tabular}

Milestone Description

Submit report identifying performance measures for Financial Services.

Description of what constitutes completion of this milestone:

Timely submission of report identifying performance measures for Financial Services.

\begin{tabular}{|ll|ll|}
\hline Cost Account Manager & Date & Program/Project Manager & Date \\
\hline Program Element Manager & Date & DOE Monitor & Date \\
\hline
\end{tabular}


3.B HBS Milestone
Description Sheet
Hestinghouse Hanford Company

Finance and Administration

WBS 6.10

FY 1995 SSPP

FINANCIAL SERVICES

WBS 6.10 .4

\section{Westinghouse Hanford Company MILESTONE DESCRIPTION SHEET}

\begin{tabular}{|c|c|c|c|}
\hline \multicolumn{3}{|c|}{ Title: Financial Administration and Control Total Quality Plan } & Date: $08 / 31 / 94$ \\
\hline \multicolumn{3}{|c|}{ Assigned To: Financial Administration } & CIN: \\
\hline \multicolumn{3}{|c|}{ Program WBS Designator: 6.10 .4 .1} & Due Date: $02 / 28 / 95$ \\
\hline \multicolumn{3}{|c|}{ Control Number: FFS-95-016 } & Revision: \\
\hline $\begin{array}{l}\text { MILESTONE TYPE: } \\
\square \text { DOE-HQ } \\
\square \text { DOE-RL } \\
\text { CNTR } \\
\end{array}$ & $\begin{array}{ll} & \text { DIVISION: } \\
\square & \text { State } \\
\square & \text { Federal } \\
\square & \text { DOE } \\
\square & \text { RCRA } \\
\square & \text { TPA\# } \\
\end{array}$ & $\begin{array}{ll} & \text { DELIVERABLE: } \\
\square & \text { Report } \\
\square & \text { Letter. } \\
\square & \text { Drawings } \\
\text { Other (specify) } \\
\text { P1an }\end{array}$ & $\begin{array}{l}\text { ADDRESS TO: } \\
\square \text { DOE-HQ } \\
\square \text { DOE-RL } \\
\text { Other (specify) } \\
\text { A11 Financial } \\
\text { Administration and } \\
\text { Control employees }\end{array}$ \\
\hline \multicolumn{4}{|l|}{ Milestone Description: } \\
\hline \multicolumn{4}{|c|}{$\begin{array}{l}\text { Produce a Financial Administration and Control Total Quality P1an for calendar year } \\
\text { 1995. }\end{array}$} \\
\hline \multicolumn{4}{|c|}{ Description of what constitutes completion of this milestone: } \\
\hline \multicolumn{4}{|c|}{ Transmittal of the plan to all Financial Administration and Control employees. } \\
\hline \multicolumn{2}{|c|}{ Cost Account Manager $\quad$ Date } & \multicolumn{2}{|c|}{ Program/Project Manager $\quad$ Date } \\
\hline \multicolumn{2}{|c|}{ Program Element Manager $\quad$ Date } & \multicolumn{2}{|c|}{ DOE Monitor Date } \\
\hline
\end{tabular}




\section{B WBS Milestone Description Sheet}

Hestinghouse Hanford Company

Finance and Administration

WBS 6.10

\section{FINANCIAL SERVICES}

WBS 6.10 .4

\section{Westinghouse Hanford Company MILESTONE DESCRIPTION SHEET}

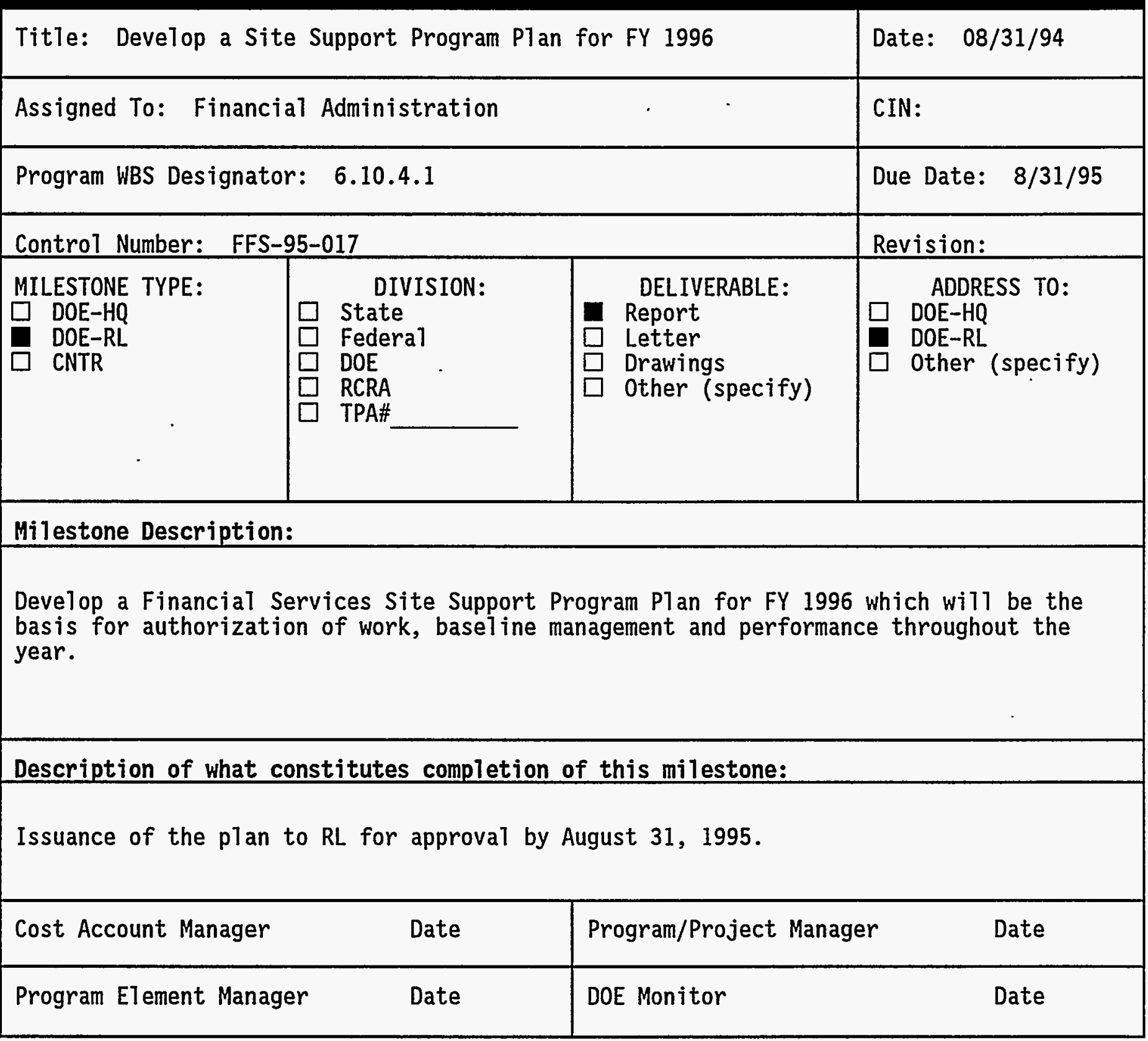




\section{B WBS Milestone Description Sheet}

Hestinghouse Hanford Company

Finance and Administration HBS 6.10

FY 1995 SSPP

FINANCIAL SERVICES

WBS 6.10 .4

\section{Westinghouse Hanford Company MILESTONE DESCRIPTION SHEET}

\begin{tabular}{|c|c|c|c|}
\hline \multicolumn{3}{|c|}{$\begin{array}{l}\text { Departmental Integrated Standardized Core Accounting } \\
\text { System (DISCAS) and Financial Information System } \\
\text { (FIS) }\end{array}$} & Date: $08 / 31 / 94$ \\
\hline \multicolumn{3}{|c|}{ Assigned To: General Accounting } & CIN: \\
\hline \multicolumn{3}{|c|}{ Program WBS Designator: 6.10 .4 .2} & $\begin{array}{l}\text { Due Date: Monthly } \\
(10 / 94-09 / 95)\end{array}$ \\
\hline \multicolumn{3}{|c|}{ Control Number: FFS-95-018 through FFS-95-029 } & Revision: \\
\hline $\begin{array}{l}\text { MILESTONE TYPE: } \\
\text { DOE-HQ } \\
\square \text { DOE-RL } \\
\square \text { CNTR }\end{array}$ & $\begin{array}{ll} & \text { DIVISION: } \\
\square & \text { State } \\
\square & \text { FederaT } \\
\square & \text { DOE } \\
\square & \text { RCRA } \\
\square & \text { TPA\# }\end{array}$ & $\begin{array}{ll} & \text { DELIVERABLE: } \\
& \text { Report } \\
\square & \text { Letter } \\
\square & \text { Drawings } \\
\square & \text { Other (specify) }\end{array}$ & $\begin{array}{l}\text { ADDRESS TO: } \\
\square \text { DOE-HQ } \\
\text { DOE-RL } \\
\square \text { Other (specify) }\end{array}$ \\
\hline \multicolumn{4}{|l|}{ Milestone Description } \\
\hline \multicolumn{4}{|c|}{ Prepare financial data input to the DISCAS and FIS. } \\
\hline \multicolumn{4}{|c|}{ Description of what constitutes completion of this milestone: } \\
\hline \multicolumn{4}{|c|}{$\begin{array}{l}\text { Timely, accurate data input to the DISCAS and FIS in accordance with specified dates } \\
\text { listed above. }\end{array}$} \\
\hline \multicolumn{2}{|c|}{ Cost Account Manager Date } & \multicolumn{2}{|c|}{ Program/Project Manager Date } \\
\hline \multicolumn{2}{|c|}{ Program Element Manager Date } & DOE Monitor & Date \\
\hline
\end{tabular}




\section{B HBS Milestone Description Sheet}

Westinghouse Hanford Company

Finance and Administration

WBS 6.10
FY 1995 SSPP

\section{FINANCIAL SERVICES \\ WBS 6.10 .4}

\section{Westinghouse Hanford Company MILESTONE DESCRIPTION SHEET}

\begin{tabular}{|c|c|c|c|}
\hline \multicolumn{3}{|c|}{ Title: Financial Statement } & Date: $08 / 31 / 94$ \\
\hline \multicolumn{3}{|c|}{ Assigned To: General Accounting } & CIN: \\
\hline \multicolumn{3}{|c|}{ Program WBS Designator: 6.10 .4 .2} & Due Date: $11 / 94$ \\
\hline \multicolumn{3}{|c|}{ Control Number: FFS-95-030 } & Revision: \\
\hline $\begin{array}{l}\text { MILESTONE TYPE: } \\
\text { DOE-HQ } \\
\text { DOE-RL } \\
\square \text { CNTR }\end{array}$ & \begin{tabular}{|ll} 
& \multicolumn{1}{c}{ DIVISION: } \\
$\square$ & State \\
0 & Federal \\
0 & DOE \\
$\square$ & RCRA \\
$\square$ & TPA\# \\
\end{tabular} & $\begin{array}{ll} & \text { DELIVERABLE: } \\
& \text { Report } \\
\square & \text { Letter } \\
0 & \text { Drawings } \\
\square & \text { Other (specify) }\end{array}$ & $\begin{array}{ll} & \text { ADDRESS TO: } \\
\square & \text { DOE-HQ } \\
\text { DOE-RL } \\
\text { Other (specify) }\end{array}$ \\
\hline \multicolumn{4}{|l|}{ Milestone Description } \\
\hline \multicolumn{4}{|c|}{ Prepare annual Financiai Statement. } \\
\hline \multicolumn{4}{|c|}{ Description of what constitutes completion of this milestone: } \\
\hline \multicolumn{4}{|c|}{$\begin{array}{l}\text { Timely, accurate preparation of WHC Financial Statements and narrative comments in } \\
\text { accordance with specified date listed above. }\end{array}$} \\
\hline \multicolumn{2}{|l|}{ Cost Account Manager } & \multicolumn{2}{|c|}{ Program/Project Manager Date } \\
\hline \multicolumn{2}{|c|}{ Program Element Manager $\quad$ Date } & \multicolumn{2}{|c|}{ DOE Monitor Date } \\
\hline
\end{tabular}




\begin{tabular}{|c|c|c|}
\hline $\begin{array}{c}\text { 3.B WBS Milestone } \\
\text { Description Sheet }\end{array}$ & $\begin{array}{c}\text { Hestinghouse Hanford Company } \\
\text { Finance and Administration } \\
\text { WBS } 6.10\end{array}$ & FY 1995 SSPP \\
\hline
\end{tabular}

FINANCIAL SERVICES

WBS 6.10 .4

\section{Westinghouse Hanford Company MILESTONE DESCRIPTION SHEET}

\begin{tabular}{|c|c|c|c|}
\hline \multicolumn{3}{|c|}{ Tit7e: Voucher Accounting for Net Expenditures Accrued (VANEA) } & Date: $08 / 31 / 94$ \\
\hline \multicolumn{3}{|c|}{ Assigned To: General Accounting } & CIN: \\
\hline \multicolumn{3}{|c|}{ Program WBS Designator: 6.10 .4 .2} & Due Date: $11 / 94$ \\
\hline \multicolumn{3}{|c|}{ Control Number: FFS-95-031 } & Revision: \\
\hline $\begin{array}{l}\text { MILESTONE TYPE: } \\
\square \text { DOE-HQ } \\
\text { DOE-RL } \\
\square \text { CNTR }\end{array}$ & \begin{tabular}{|ll} 
& \multicolumn{1}{c}{ DIVISION: } \\
$\square$ & State \\
$\square$ & Federat \\
$\square$ & DOE \\
$\square$ & RCRA \\
$\square$ & TPA\# \\
\end{tabular} & $\begin{array}{ll} & \text { DELIVERABLE: } \\
& \text { Report } \\
\square & \text { Letter } \\
\square & \text { Drawings } \\
\square \text { Other (specify) }\end{array}$ & $\begin{array}{ll} & \text { ADDRESS TO: } \\
\square & \text { DOE-HQ } \\
\text { DOE-RL } \\
\square \text { Other (specify) }\end{array}$ \\
\hline \multicolumn{4}{|l|}{ Milestone Description } \\
\hline \multicolumn{4}{|c|}{ Prepare annuaT VANEA report. } \\
\hline \multicolumn{4}{|c|}{ Description of what constitutes completion of this milestone: } \\
\hline \multicolumn{4}{|c|}{$\begin{array}{l}\text { Timely, accurate preparation of the VANEA report in accordance with specified date } \\
\text { listed above. }\end{array}$} \\
\hline \multicolumn{2}{|c|}{ Cost Account Manager Date } & \multicolumn{2}{|c|}{ Program/Project Manager Date } \\
\hline \multicolumn{2}{|c|}{ Program Element Manager } & \multicolumn{2}{|c|}{ DOE Monitor Date } \\
\hline
\end{tabular}


3.B WBS Milestone Description Sheet
Westinghouse Hanford Company

Finance and Administration

WBS 6.10

FINANCIAL SERVICES

WBS 6.10 .4

\section{Westinghouse Hanford Company MILESTONE DESCRIPTION SHEET}

Title: Financial Systems Integration Briefing

Date: $08 / 31 / 94$

Assigned To: Financial Operations

CIN:

Program WBS Designator: 6.10 .4 .2

Due Date: $11 / 1 / 94$

Control Number: FFS-95-032

MILESTONE TYPE:

$\square$ DOE-HQ

DOE-RL

CNTR

\begin{tabular}{l} 
DIVISION: \\
State \\
Sederal \\
DOE \\
$\square$ RCRA \\
$\square$ TPA\# \\
\hline
\end{tabular}

Revision:

$\square$ Report

$\square$ Letter

$\square$ Drawings

- Other (specify)

Presentation to RL

MiTestone Description:

Brief RL on the current integration of systems containing financial data, and activities in progress to improve that integration plus incorporate technology advancements.

Description of what constitutes completion of this milestone:

Completion of the presentation to RL.

\begin{tabular}{|ll|ll|}
\hline Cost Account Manager & Date & Program/Project Manager & Date \\
\hline Program Element Manager & Date & DOE Monitor & Date \\
\hline
\end{tabular}


3.B WBS Hilestone Description Sheet
Hestinghouse Hanford Company

Finance and Administration WBS 6.10
FY 1995 SSPP.

FINANCIAL SERVICES

WBS 6.10 .4

\section{Westinghouse Hanford Company MILESTONE DESCRIPTION SHEET}

Title: Imaging Software for the Accounts Payable System

Date: $08 / 31 / 94$

Assigned To: Disbursements Accounting

CIN:

Program WBS Designator: 6.10 .4 .2

Due Date: $11 / 1 / 94$

Control Number: FFS-95-033

MILESTONE TYPE:

$\square$ DOE-HQ

$\square$ DOE-RL

- CNTR

\begin{tabular}{ll}
\multicolumn{1}{c}{ DIVISION: } \\
$\square$ State \\
$\square$ FederaI \\
$\square$ DOE \\
$\square$ RCRA \\
$\square \quad$ TPA\# \\
\end{tabular}

Revision:

\begin{tabular}{|l|l|}
\multicolumn{1}{l|}{ DELIVERABLE: } & \multicolumn{1}{c|}{ ADDRESS TO: } \\
$\square$ Report & $\square$ DOE-HQ \\
$\square$ Letter & $\square$ DOE-RL (specify) \\
$\square$ Drawings \\
Other (specify) \\
Other (specifore and code
\end{tabular}

Milestone Description:

Complete the installation and operational startup of Imaging Software for the Accounts Payable System.

Description of what constitutes completion of this milestone:

Accounts Payable acceptance of production release.

\begin{tabular}{|ll|ll|}
\hline Cost Account Manager & Date & Program/Project Manager . & Date \\
\hline Program Element Manager & Date & DOE Monitor & Date \\
\hline
\end{tabular}


3.B HBS Milestone Description Sheet
Westinghouse Hanford Company

Finance and Administration WBS 6.10

FINANCIAL SERVICES

WBS 6.10 .4

\section{Westinghouse Hanford Company MILESTONE DESCRIPTION SHEET}

Title: Multiple Performing Organizations

Date: $08 / 31 / 94$

Assigned To: General Accounting

CIN:

Program WBS Designator: 6.10 .4 .2

Due Date: $11 / 05 / 94$

(i.e., October month-end reports)

Control Number: FFS-95-034

MILESTONE TYPE:

DOE-HQ

DOE-RL

CNTR

\begin{tabular}{ll} 
DIVISION: \\
$\square$ State \\
$\square$ & Federa1 \\
$\square$ & DOE \\
$\square$ & RCRA \\
$\square$ & TPA\# \\
\hline
\end{tabular}

DELIVERABLE:

$\square$ Report

$\square$ Letter

$\square$ Drawings

other (specify)

program code changes
Revision:

ADDRESS TO:

DOE-HQ

DOE-RL

Other (specify)

financial system users

Milestone Description:

Reflect, in the financial system's performance reports, the capability of having multiple performing organizations per task package.

Description of what constitutes completion of this milestone:

Production performance reports from the financial system show budgets and variances that reflect unique budgeted labor rates and adders within task packages that have more than one organization performing work within the task package.

\begin{tabular}{|ll|ll|}
\hline Cost Account Manager & Date & Program/Project Manager & Date \\
\hline Program Element Manager & Date & DOE Monitor & Date \\
\hline
\end{tabular}


3.B WBS Milestone Description Sheet
Westinghouse Hanford Company

Finance, and Administration

WBS 6.10

\section{FINANCIAL SERVICES}

WBS 6.10 .4

\section{Westinghouse Hanford Company MILESTONE DESCRIPTION SHEET}

\begin{tabular}{|c|c|c|c|}
\hline \multicolumn{3}{|c|}{ Title: Financial Systems Integration } & Date: $08 / 31 / 94$ \\
\hline \multicolumn{3}{|c|}{ Assigned To: General Accounting } & CIN: \\
\hline \multicolumn{3}{|c|}{ Program WBS Designator: 6.10 .4 .2} & $\begin{array}{l}\text { Due Date: } 11 / 05 / 94 \\
\text { (i.e., October } \\
\text { month-end reports) }\end{array}$ \\
\hline \multicolumn{3}{|c|}{ Control Number: FFS-95-035 } & Revision: \\
\hline $\begin{array}{l}\text { MILESTONE TYPE: } \\
\square \text { DOE-HQ } \\
\text { DOE-RL } \\
\square \text { CNTR }\end{array}$ & \begin{tabular}{|ll} 
& DIVISION: \\
$\square$ & State \\
0 & Federal \\
0 & DOE \\
$\square$ & RCRA \\
$\square$ & TPA\# \\
\end{tabular} & $\begin{array}{l}\text { DELIVERABLE: } \\
\square \text { Report } \\
\square \text { Letter } \\
\square \text { Drawings } \\
\text { Other (specify) } \\
\text { program code changes }\end{array}$ & 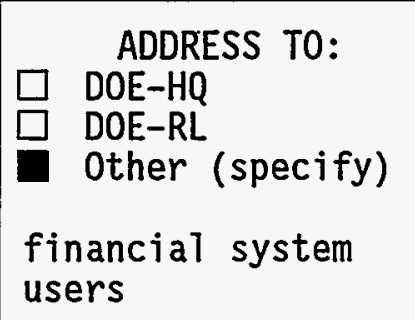 \\
\hline
\end{tabular}

Milestone Description:

Complete the integration of the ICF KH and WHC/BCSR financial systems (i.e., the last of the business systems to be integrated).

\section{Description of what constitutes completion of this milestone:}

ICF KH data processes through the WHC/BCSR financial system and is reflected in the WHC/BCSR financial system's reports.

\begin{tabular}{|ll|ll|}
\hline Cost Account Manager & Date & Program/Project Manager & Date \\
\hline Program Element Manager & Date & DOE Monitor & Date \\
\hline
\end{tabular}




\section{B. HBS Milestone Description Sheet}

Westinghouse Hanford Company

Finance and Administration

WBS 6.10

FY 1995 SSPP

\section{FINANCIAL SERVICES}

HBS 6.10 .4

\section{Westinghouse Hanford Company MILESTONE DESCRIPTION SHEET}

\begin{tabular}{|c|c|c|c|}
\hline $\begin{array}{l}\text { Implement } \\
\text { for vendo }\end{array}$ & $\begin{array}{l}\text { Electronic Funds } \\
\text { payments }\end{array}$ & fer (EFT) capability & Date: $08 / 31 / 94$ \\
\hline Assigned To: Disburs & ments Accounting & & CIN: \\
\hline Program WBS Designato & $r: \quad 6.10 .4 .2$ & & Due Date: $12 / 1 / 94$ \\
\hline Control Number: FFS- & $95-036$ & & Revision: \\
\hline $\begin{array}{l}\text { MILESTONE TYPE: } \\
\square \text { DOE-HQ } \\
\square \text { DOE-RL } \\
\text { CNTR }\end{array}$ & 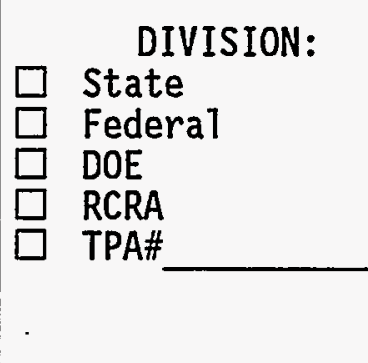 & $\begin{array}{ll} & \text { DELIVERABLE: } \\
\square & \text { Report } \\
\square & \text { Letter } \\
& \text { Drawings } \\
\text { Other (specify) } & \\
\text { software and } \\
\text { hardware (modems) }\end{array}$ & 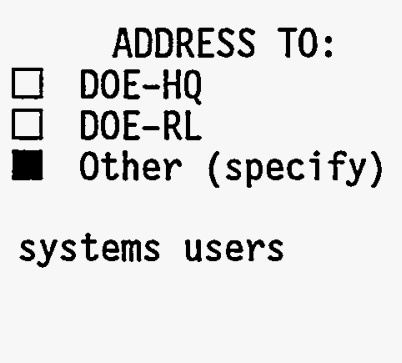 \\
\hline Milestone Description & & & \\
\hline Implement Electronic & Funds Transfer (EF & pability for vendor $p$ & ments. \\
\hline Description of what $c$ & onstitutes complet & $f$ this milestone: & \\
\hline $\begin{array}{l}\text { Test five selected ve } \\
\text { production use. }\end{array}$ & ndors; based upon & sful testing, will b & implemented for \\
\hline Cost Account Manager & Date & Program/Project Mana & Date \\
\hline Program Element Manag & Date & DOE Monitor & Date \\
\hline
\end{tabular}


3.B WBS Milestone Description Sheet
Westinghouse Hanford Company

Finance and Administration

HBS 6.10

FY 1995 SSPP

FINANCIAL SERVICES

WBS 6.10 .4

\section{Westinghouse Hanford Company MILESTONE DESCRIPTION SHEET}

Tit7e: Updated Submittal-Impacts of Downsizing Report

Date: $08 / 31 / 94$

Assigned To: General Accounting

CIN :

Program WBS Designator: 6.10 .4 .2

Due Date: $12 / 15 / 94$

Control Number: FFS-95-037

MILESTONE TYPE:

$\square$ DOE-HQ

DOE-RL

CNTR

\begin{tabular}{|ll}
\multicolumn{1}{c}{ DIVISION: } \\
$\square$ & State \\
$\square$ & Federal \\
$\square$ & DOE \\
$\square$ & RCRA \\
$\square$ & TPA\# \\
\end{tabular}

Revision:

DELIVERABLE:

Report

Letter

Drawings

Other (specify)
ADDRESS TO:

$\square$ DOE-HQ

DOE-RL

$\square$ Other (specify)

\section{Milestone Description}

Submit updated report pertaining to the effects of the BHI Transition as well as downsizing as a result of other factors.

\section{Description of what constitutes completion of this milestone:}

Timely submission of update report detailing the effects on the Financial Services organization associated with the BHI Transition, and update the effects from downsizing as a result of other factors. Additional1y, this report will detail Financial

Services' strategy(s) to alleviate the effects of the downsizing.

\begin{tabular}{|ll|ll|}
\hline Cost Account Manager & Date & Program/Project Manager & Date \\
\hline Program Element Manager & Date & DOE Monitor & Date \\
\hline
\end{tabular}




\section{B WBS Milestone Description Sheet}

Westinghouse Hanford Company

Finance and Administration

WBS 6.10

\section{FINANCIAL SERVICES}

WBS 6.10 .4

\section{Westinghouse Hanford Company MILESTONE DESCRIPTION SHEET}

\begin{tabular}{|c|c|c|c|}
\hline \multicolumn{3}{|c|}{ Title: Financial Business Requirements Plan } & Date: $08 / 31 / 94$ \\
\hline \multicolumn{3}{|c|}{ Assigned To: Financial Operations } & CIN: \\
\hline \multicolumn{3}{|c|}{ Program WBS Designator: 6.10 .4 .2} & Due Date: $12 / 15 / 94$ \\
\hline \multicolumn{3}{|c|}{ Control Number: FFS-95-038 } & Revision: \\
\hline $\begin{array}{l}\text { MILESTONE TYPE: } \\
\square \text { DOE-HQ } \\
\square \text { DOE-RL } \\
\square \text { CNTR }\end{array}$ & \begin{tabular}{ll}
\multicolumn{1}{c}{ DIVISION: } \\
$\square$ State \\
$\square$ Federal \\
$\square$ DOE \\
$\square$ & RCRA \\
$\square$ & TPA\# \\
\end{tabular} & $\begin{array}{l}\text { DELIVERABLE: } \\
\square \text { Report } \\
\square \text { Letter } \\
\square \text { Drawings } \\
\text { Other (specify) } \\
\text { Plan }\end{array}$ & $\begin{array}{l}\text { ADDRESS TO: } \\
\text { DOE-HQ } \\
\text { DOE-RL } \\
\text { Other (specify) }\end{array}$ \\
\hline \multicolumn{4}{|l|}{ Milestone Description: } \\
\hline \multicolumn{4}{|c|}{$\begin{array}{l}\text { Prepare a plan for determining the changing business requirements that need to be met } \\
\text { by the financial system(s), including programmatic requirements as well as overal1 WHC } \\
\text { and RL requirements. An example of such changing business requirements, which has } \\
\text { immediate emphasis, is the creation of incentive programs. }\end{array}$} \\
\hline \multicolumn{4}{|c|}{ Description of what constitutes completion of this milestone: } \\
\hline \multicolumn{4}{|c|}{ Transmittal of the plan to RL and applicable WHC parties. } \\
\hline \multicolumn{2}{|l|}{ Cost Account Manager } & \multicolumn{2}{|c|}{ Program/Project Manager Date } \\
\hline \multicolumn{2}{|l|}{ Program Element Manager } & DOE Monitor & Date \\
\hline
\end{tabular}


WBS 6.10

FINANCIAL SERVICES

WBS 6.10 .4

\section{Westinghouse Hanford Company MILESTONE DESCRIPTION SHEET}

\begin{tabular}{|c|c|c|c|}
\hline \multicolumn{3}{|c|}{ Title: Time Information System First Release } & Date: $08 / 31 / 94$ \\
\hline \multicolumn{3}{|c|}{ Assigned To: Financial Operations } & CIN: \\
\hline \multicolumn{3}{|c|}{ Program WBS Designator: 6.10 .4 .2} & Due Date: $12 / 31 / 94$ \\
\hline \multicolumn{3}{|c|}{ Control Number: FFS-95-039 } & Revision: \\
\hline $\begin{array}{l}\text { MILESTONE TYPE: } \\
\square \text { DOE-HQ } \\
\square \text { DOE-RL } \\
\text { CNTR }\end{array}$ & \begin{tabular}{ll}
\multicolumn{1}{c}{ DIVISION: } \\
$\square$ & State \\
$\square$ & FederaT \\
$\square$ & DOE \\
$\square$ & RCRA \\
$\square$ & TPA\# \\
\end{tabular} & $\begin{array}{ll} & \text { DELIVERABLE: } \\
\square & \text { Report } \\
\square & \text { Letter } \\
\square & \text { Drawings } \\
\text { Other (specify) } & \\
\text { program code }\end{array}$ & $\begin{array}{l}\text { ADDRESS TO: } \\
\square \text { DOE-HQ } \\
\square \text { DOE-RL } \\
\text { Other (specify) } \\
\text { first group of TIS } \\
\text { users }\end{array}$ \\
\hline \multicolumn{4}{|l|}{ Milestone Description: } \\
\hline \multicolumn{4}{|c|}{ Implement the first functional release of the Time Information System (TIS). } \\
\hline \multicolumn{4}{|c|}{ Description of what constitutes completion of this milestone: } \\
\hline \multicolumn{4}{|c|}{$\begin{array}{l}\text { Time Card and Time Distribution Report (TDR) data, for the first group of TIS users, is } \\
\text { input electronically into the TIS, and subsequentiy transferred automatically into the } \\
\text { payrol1 and financial systems. }\end{array}$} \\
\hline \multicolumn{2}{|l|}{ Cost Account Manager } & \multicolumn{2}{|c|}{ Program/Project Manager Date } \\
\hline \multicolumn{2}{|c|}{ Program Element Manager $\quad$ Date } & \multicolumn{2}{|l|}{ DOE Monitor } \\
\hline
\end{tabular}




\section{B HBS Milestone Description Sheet}

Westinghouse Hanford Company

Finance and Administration

WBS 6.10

FY 1995 SSPP

\section{FINANCIAL SERVICES}

WBS 6.10 .4

\section{Westinghouse Hanford Company MILESTONE DESCRIPTION SHEET}

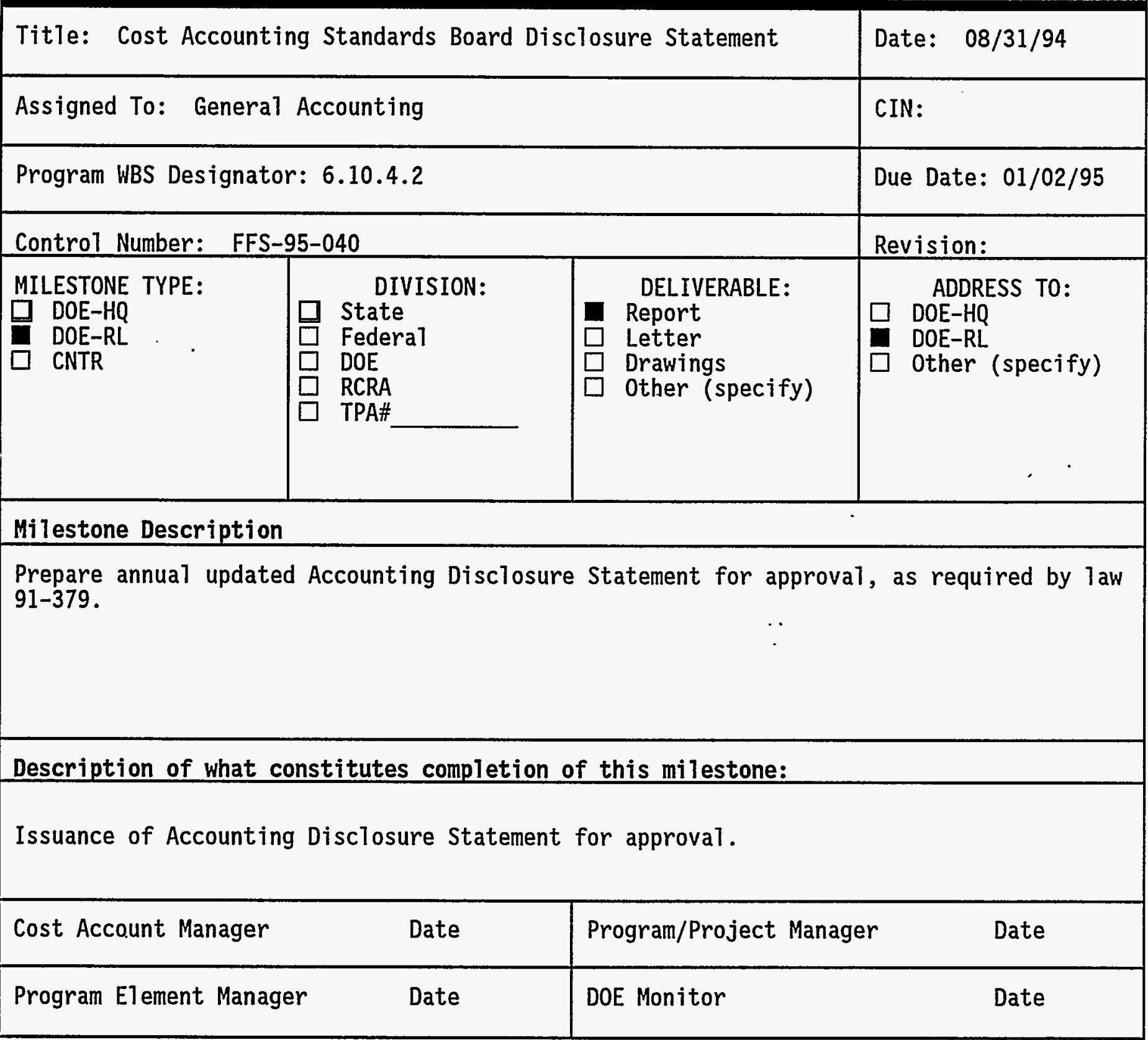


3.B WBS Milestone Description Sheet
Westinghouse Hanford Company

Finance and Administration

HBS 6.10

FY 1995 SSPP

FINANCIAL SERVICES

HBS 6.10 .4

\section{Westinghouse Hanford Company MILESTONE DESCRIPTION SHEET}

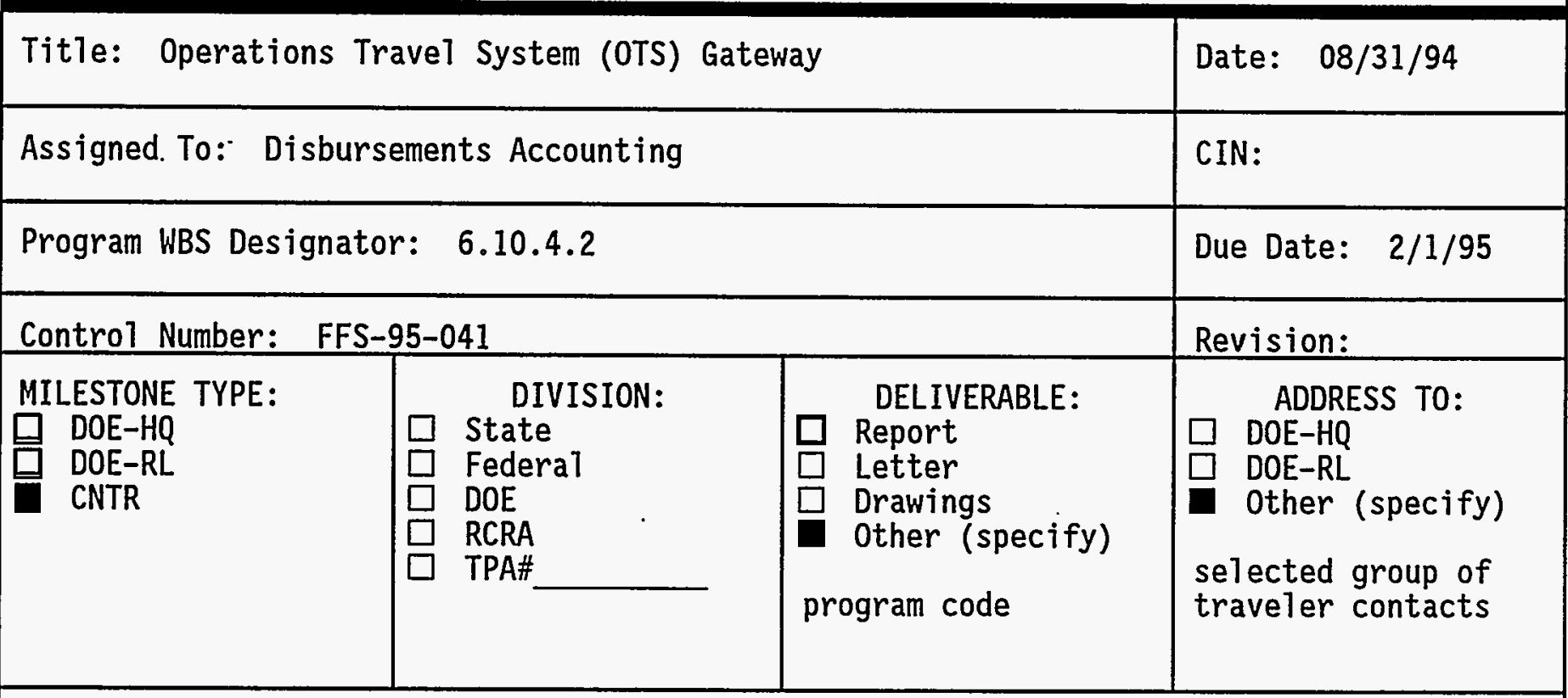

Milestone Description:

Implement Operations Travel System Gateway use by a small number of high volume users.

Description of what constitutes completion of this milestone:

Travel data for this selected group of users is able to be input by them electronically into the OTS.

\begin{tabular}{|ll|ll|}
\hline Cost Account Manager & Date & Program/Project Manager & Date \\
\hline Program Element Manager & Date & DOE Monitor & Date \\
\hline
\end{tabular}


3.B WBS Milestone Description Sheet
Hestinghouse Hanford Company

Finance and Administration

WBS 6.10

FY 1995 SSPP

\section{FINANCIAL SERVICES}

WBS 6.10 .4

\section{Westinghouse Hanford Company MILESTONE DESCRIPTION SHEET}

\begin{tabular}{|c|c|c|c|}
\hline \multicolumn{3}{|c|}{$\begin{array}{ll}\text { Title: } & \begin{array}{l}\text { Management Analysis and Reporting Systems - Standard } \\
\text { Genera1 Ledger (MARS-SGL) }\end{array} \\
\end{array}$} & Date: $08 / 31 / 94$ \\
\hline \multicolumn{3}{|c|}{ Assigned To: General Accounting } & CIN: \\
\hline \multicolumn{3}{|c|}{ Program WBS Designator: 6.10 .4 .2} & Due Date: $02 / 95$ \\
\hline \multicolumn{3}{|c|}{ Control Number: FFS-95-042 } & Revision: \\
\hline $\begin{array}{l}\text { MILESTONE TYPE: } \\
\text { DOE-HQ } \\
\square . \text { DOE-RL } \\
\square \text { CNTR } \\
\end{array}$ & $\begin{array}{ll} & \text { DIVISION: } \\
\square & \text { State } \\
\square & \text { Federa1 } \\
\square & \text { DOE } \\
\square & \text { RCRA } \\
\square & \text { TPA\# } \\
\end{array}$ & $\begin{array}{ll} & \text { DELIVERABLE: } \\
\square & \text { Report } \\
\text { Letter } \\
\text { Drawings } \\
\text { Other (specify) } \\
\text { Other } \\
\text { Submit DISCAS file } \\
\text { records in expanded } \\
\text { MARS format. }\end{array}$ & $\begin{array}{ll} & \text { ADDRESS TO: } \\
\square & \text { DOE-HQ } \\
\text { DOE-RL } \\
\text { 0ther (specify) }\end{array}$ \\
\hline \multicolumn{4}{|l|}{ Milestone Description } \\
\hline \multicolumn{4}{|c|}{ Implementation of MARS/SGL phase II. } \\
\hline \multicolumn{4}{|c|}{ Description of what constitutes completion of this milestone: } \\
\hline \multicolumn{4}{|c|}{ January, and subsequent, DISCAS records submitted in expanded MARS format. } \\
\hline Cost Account Manager & Date & Program/Project Mana & Date \\
\hline Program Element Manas & Date & DOE Monitor & Date \\
\hline
\end{tabular}




\section{B WBS Milestone Description Sheet}

Hestinghouse Hanford Company

Finance and Administration

WBS 6.10

FINANCIAL SERVICES

HBS 6.10 .4

\section{Westinghouse Hanford Company MILESTONE DESCRIPTION SHEET}

Title: Scannable Time Sheets

Date: $08 / 31 / 94$

Assigned To: Disbursements Accounting

CIN:

Program WBS Designator: 6.10.4.2

Due Date: $3 / 31 / .95$

Control Number: FFS-95-043

MILESTONE TYPE:

$\square$ DOE-HQ

DOE-RL

CNTR

\begin{tabular}{|l}
\multicolumn{1}{c}{ DIVISION: } \\
$\square$ State \\
$\square$ Federal \\
$\square$ DOE \\
$\square$ RCRA \\
$\square$ TPA\# \\
\end{tabular}

Revision:

DELIVERABLE:

$\square$ Report

$\square$ Letter

$\square$ Drawings

Other (specify)

hardware and code
ADDRESS TO:

$\square$ DOE-HQ

$\square$ DOE-RL

Other (specify)

systems users

Milestone Description:

Complete the installation and startup of Scannable Time Sheets for Exempt Payroll, Savings Bond and United Way Campaigns.

Description of what constitutes completion of this milestone:

Payrol1 acceptance of production release.

\begin{tabular}{|ll|ll|}
\hline Cost Account Manager & Date & Program/Project Manager & Date \\
\hline Program Element Manager & Date & DOE Monitor & Date \\
\hline
\end{tabular}


3.B HBS Milestone Description Sheet
Hestinghouse Hanford Company

Finance and Administration WBS 6.10

FINANCIAL SERVICES

HBS 6.10 .4

\section{Westinghouse Hanford Company MILESTONE DESCRIPTION SHEET}

Title: Financial Management System Input

Date: $08 / 31 / 94$

Assigned To: Financial Operations

CIN:

Program WBS Designator: 6.10 .4 .2

Control Number: FFS-95-044

MILESTONE TYPE:

$\square$ DOE-HQ

DOE-RL

CNTR

\begin{tabular}{|ll}
\multicolumn{1}{c|}{ DIVISION: } \\
$\square$ & State \\
$\square$ & Federal \\
$\square$ & DOE \\
$\square$ & RCRA \\
$\square$ & TPA\# \\
&
\end{tabular}

DELIVERABLE:

$\square$ Report

Letter

$\square$ Drawings

$\square$ Other (specify)
Due Date: Per RL schedule (was 4/4/94 in prior year) Revision:

ADDRESS TO:

DOE-HQ

DOE-RL

Other (specify)

Milestone Description:

Submit input of financial management system information for the Chief Financial

Officer's five-year plan, per instructions in annual DOE call letter.

Description of what constitutes completion of this milestone:

Transmittal of input to RL.

\begin{tabular}{|ll|ll|}
\hline Cost Account Manager & Date & Program/Project Manager & Date \\
\hline Program Element Manager & Date & DOE Monitor & Date \\
\hline
\end{tabular}


3.B HBS Milestone Description Sheet
Hestinghouse Hanford Company

Finance and Administration WBS 6.10

FINANCIAL SERVICES

WBS 6.10 .4

\section{Westinghouse Hanford Company MILESTONE DESCRIPTION SHEET}

Title: Property Record Unit Catalog

Date: $08 / 31 / 94$

Assigned To: General Accounting

CIN:

Program WBS Designator: 6.10 .4 .2

Due Date: $06 / 15 / 95$

Control Number: FFS-95-045

MILESTONE TYPE:

$\square$ DOE-HQ

$\square$ DOE-RL

CNTR

$\begin{array}{|ll|} & \text { DIVISION: } \\ \square & \text { State } \\ \square & \text { Federal } \\ \square & \text { DOE } \\ \square & \text { RCRA } \\ \square & \text { TPA\# }\end{array}$

DELIVERABLE:

- Report

$\square$ Letter

$\square$ Drawings

$\square$ Other (specify)

Revision:

ADDRESS TO:

DOE-HQ

DOE-RL

Other (specify)

Milestone Description

Prepare annual updated Property Record unit catalog.

Description of what constitutes completion of this milestone:

Timely, accurate update of the Property Record unit catalog in accordance with specified execution date listed above.

\begin{tabular}{|ll|ll|}
\hline Cost Account Manager & Date & Program/Project Manager & Date \\
\hline Program Element Manager & Date & DOE Monitor & Date \\
\hline
\end{tabular}


3.B WBS Milestone Description Sheet
Westinghouse Hanford Company

Finance and Administration

WBS 6.10

FY 1995 SSPP

FINANCIAL SERVICES

WBS 6.10 .4

\section{Westinghouse Hanford Company MILESTONE DESCRIPTION SHEET}

\begin{tabular}{|c|c|c|c|}
\hline \multicolumn{3}{|c|}{ Title: Closing \& Startup Schedule for FY 1995 and FY 1996} & Date: $08 / 31 / 94$ \\
\hline \multicolumn{3}{|c|}{ Assigned To: General Accounting } & CIN: \\
\hline \multicolumn{3}{|c|}{ Program WBS Designator: 6.10 .4 .2} & Due Date: $07 / 14 / 95$ \\
\hline \multicolumn{3}{|c|}{ Control Number: FFS-95-046 } & Revision: \\
\hline $\begin{array}{l}\text { MILESTONE TYPE: } \\
\square \text { DOE-HQ } \\
\square \text { DOE-RL } \\
\text { CNTR }\end{array}$ & $\begin{array}{ll} & \text { DIVISION: } \\
& \text { State } \\
\square & \text { Federal } \\
\square & \text { DOE } \\
\square & \text { RCRA } \\
\square & \text { TPA\# } \\
\end{array}$ & $\begin{array}{ll} & \text { DELIVERABLE: } \\
& \text { Report } \\
\square & \text { Letter } \\
\square & \text { Drawings } \\
\square & \text { Other (specify) }\end{array}$ & $\begin{array}{ll} & \text { ADDRESS TO: } \\
\square & \text { DOE-HQ } \\
\text { DOE-RL } \\
\text { Other (specify) }\end{array}$ \\
\hline \multicolumn{4}{|l|}{ Milestone Description } \\
\hline \multicolumn{4}{|c|}{ Prepare detailed Closing and Startup Schedule for FY 1995 and FY 1996, respectively. } \\
\hline \multicolumn{4}{|c|}{ Description of what constitutes completion of this milestone: } \\
\hline \multicolumn{4}{|c|}{$\begin{array}{l}\text { Timely preparation of a Closing and Startup Schedule for FY } 1995 \text { and FY 1996, } \\
\text { respectively. The Schedule shall include activities and tentative dates associated } \\
\text { with Yearend Closing and Fiscal Year Startup. }\end{array}$} \\
\hline \multicolumn{2}{|c|}{ Cost Account Manager $\quad$ Date } & \multicolumn{2}{|c|}{ Program/Project Manager Date } \\
\hline \multicolumn{2}{|c|}{ Program Element Manager Date } & \multicolumn{2}{|c|}{ DOE Monitor Date } \\
\hline
\end{tabular}


3.B WBS Milestone Description Sheet
Westinghouse Hanford Company

Finance and Administration

WBS 6.10

FINANCIAL SERVICES

WBS 6.10 .4

\section{Westinghouse Hanford Company MILESTONE DESCRIPTION SHEET}

Title: Interface Freight Billing and Accounts Payable

Date: $08 / 31 / 94$

Assigned To: Disbursements Accounting

CIN:

Program WBS Designator: 6.10.4.2

Due Date: $07 / 31 / 95$

Control Number: FFS-95-047

MILESTONE TYPE:

$\square$ DOE-HQ

$\square$ DOE-RL

CNTR

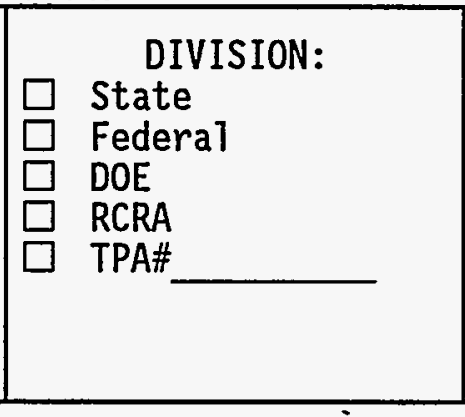

Revision:

DELIVERABLE:
$\square$ Report
$\square$. Letter
$\square$ Drawings
$\square$ Other (specify)
program code changes

ADDRESS TO:

$\square \quad$ DOE-HQ

$\square$ DOE-RL

- Other (specify)

Accounts Payable system users

\section{Milestone Description:}

Implement an automated interface between the freight billing system and the accounts payable system.

Description of what constitutes completion of this milestone:

Program code changes installed into production coding for Accounts Payable system.

\begin{tabular}{|ll|ll|}
\hline Cost Account Manager & Date & Program/Project Manager & Date \\
\hline Program Element Manager & Date & DOE Monitor & Date \\
\hline
\end{tabular}




\section{B WBS Milestone Description Sheet}

Westinghouse Hanford Company

Finance and Administration

WBS 6.10

\section{FINANCIAL SERVICES}

WBS 6.10 .4

\section{Westinghouse Hanford Company MILESTONE DESCRIPTION SHEET}

\begin{tabular}{|c|c|c|c|}
\hline Title: Kaiser Projec & t Control Number & ment & Date: $08 / 31 / 94$ \\
\hline Assigned To: General & Accounting & & CIN: \\
\hline Program WBS Designato & $r: \quad 6.10 .4 .2$ & & Due Date: $08 / 1 / 95$ \\
\hline Control Number: FFS- & $95-048$ & & Revision: \\
\hline $\begin{array}{l}\text { MILESTONE TYPE: } \\
\square \text { DOE-HQ } \\
\square \text { DOE-RL } \\
\text { CNTR }\end{array}$ & $\begin{array}{ll} & \text { DIVISION: } \\
& \text { State } \\
\square & \text { Federal } \\
\square & \text { DOE } \\
\square & \text { RCRA } \\
\square & \text { TPA\# } \\
\end{array}$ & $\begin{array}{ll} & \text { DELIVERABLE: } \\
\square & \text { Report } \\
\square \text { Letter } \\
\square \text { Drawings } \\
\text { Other (specify) } \\
\text { program code changes }\end{array}$ & $\begin{array}{l}\text { ADDRESS TO: } \\
\square \text { DOE-HQ } \\
\square \text { DOE-RL } \\
\text { Other (specify) } \\
\text { financial system } \\
\text { users }\end{array}$ \\
\hline Milestone Description & & & \\
\hline $\begin{array}{l}\text { Expand the financial } \\
\text { include Kaiser Projec }\end{array}$ & $\begin{array}{l}\text { system's purge pr } \\
\text { Control Numbers }\end{array}$ & $\begin{array}{l}\text { and modify master (MODN } \\
\text { ). }\end{array}$ & AAST) process to \\
\hline Description of what $c$ & onstitutes comple & this milestone: & \\
\hline Program code changes & installed into $\mathrm{pr}$ & on coding for financial & system. \\
\hline Cost Account Manager & Date & Program/Project Manage & Date \\
\hline Program Element Manag & Date & DOE Monitor & Date \\
\hline
\end{tabular}




\section{B WBS Milestone Description Sheet}

Hestinghouse Hanford Company

Finance and Administration

WBS 6.10

FY 1995 SSPP

FINANCIAL SERVICES

WBS 6.10 .4

\section{Westinghouse Hanford Company MILESTONE DESCRIPTION SHEET}

Title: Time Information System Full Implementation

Date: $08 / 31 / 94$

Assigned To: Financial Operations

CIN:

Program WBS Designator: 6.10 .4 .2

Due Date: $09 / 30 / 95$

Control Number: FFS-95-049

MILESTONE TYPE:

DOE-HQ

DOE-RL

CNTR

\begin{tabular}{|l}
\multicolumn{1}{c}{ DIVISION: } \\
$\square$ State \\
Federal \\
$\square$ DOE \\
$\square$ RCRA \\
$\square$ TPA\# \\
\hline
\end{tabular}

Revision:

DELIVERABLE:

Report

Letter

Drawings

Other (specify)

program code

ADDRESS TO:

$\square$ DOE-HQ

$\square$ DOE-RL

Other (specify)

TIS users across WHC

Milestone Description:

TIS implemented for all WHC/ICF KH/BCSR organizations.

Description of what constitutes completion of this milestone:

Time Card and Time Distribution Report (TDR) data, for all of WHC, ICF KH, BCSR, is input electronically into the TIS, and subsequently transferred automatically into the payroll and financial systems.

\begin{tabular}{|ll|ll|}
\hline Cost Account Manager & Date & Program/Project Manager & Date \\
\hline Program Element Manager & Date & DOE Monitor & Date \\
\hline
\end{tabular}




\section{B WBS Milestone} Description Sheet
Hestinghouse Hanford Company

Finance and Administration

WBS 6.10

FINANCIAL SERVICES

HBS 6.10 .4

\section{Westinghouse Hanford Company MILESTONE DESCRIPTION SHEET}

\begin{tabular}{|c|c|c|c|}
\hline \multicolumn{3}{|c|}{$\begin{array}{l}\text { Identify and implement business changes to provide } \\
\text { Electronic Data Interchange capabilities within the } \\
\text { Accounts Payable System }\end{array}$} & $08 / 31 / 94$ \\
\hline \multicolumn{3}{|c|}{ Assigned To: Disbursements Accounting } & CIN: \\
\hline \multicolumn{3}{|c|}{ Program WBS Designator: 6.10 .4 .2} & Due Date: $9 / 30 / 95$ \\
\hline \multicolumn{3}{|c|}{ Control Number: FFS-95-050 } & Revision: \\
\hline $\begin{array}{l}\text { MILESTONE TYPE: } \\
\square \text { DOE-HQ } \\
\text { DOE-RL } \\
\square \text { CNTR }\end{array}$ & $\begin{array}{ll} & \text { DIVISION: } \\
\square & \text { State } \\
\square & \text { Federal } \\
\text { DOE } \\
\text { DCRA } \\
\square \text { TPA\# } \\
\end{array}$ & $\begin{array}{l}\text { DELIVERABLE: } \\
\square \text { Report } \\
\square \text { Letter } \\
\square \text { Drawings } \\
\text { Other (specify) } \\
\text { program code changes }\end{array}$ & $\begin{array}{l}\text { ADDRESS TO: } \\
\square \text { DOE-HQ } \\
\square \text { DOE-RL } \\
\text { Other (specify) } \\
\text { Accounts Payable } \\
\text { system users }\end{array}$ \\
\hline \multicolumn{4}{|l|}{ Milestone Description: } \\
\hline \multicolumn{4}{|c|}{$\begin{array}{l}\text { Identify and implement the required Accounts Payable system and administrative business } \\
\text { changes to accomplish vendor invoices and associated WHC payments via Electronic Data } \\
\text { Interchange. }\end{array}$} \\
\hline \multicolumn{4}{|c|}{ Description of what constitutes completion of this milestone: } \\
\hline \multicolumn{4}{|c|}{$\begin{array}{l}\text { Test with selected vendors; based upon successful testing, wil1 be implemented for } \\
\text { production use. }\end{array}$} \\
\hline \multicolumn{2}{|l|}{ Cost Account Manager } & \multicolumn{2}{|c|}{ Program/Project Manager $\quad$ Date } \\
\hline \multicolumn{2}{|c|}{ Program Element Manager } & \multicolumn{2}{|l|}{ DOE Monitor } \\
\hline
\end{tabular}




\section{B WBS Milestone Description Sheet}

Westinghouse Hanford Company

Finance and Administration

WBS 6.10
FY 1995 SSPP.

FINANCIAL SERVICES

WBS 6.10 .4

\section{Westinghouse Hanford Company MILESTONE DESCRIPTION SHEET}

Title: Quarterly DARTS and Status Reports

Date: $08 / 31 / 94$

Assigned To: Financial Review and Audits

CIN:

Program WBS Designator: 6.10 .4 .3

Due Date:

10 working days

after the end of

each quarter

Control Number: FFS-95-051 through FFS-95-054

MILESTONE TYPE:

DIVISION:

Revision:

$\square$ DOE-HQ

State

DOE-RL

Federal

CNTR

\begin{tabular}{ll}
$\square$ & Federa1 \\
$\square$ & DOE \\
$\square$ & RCRA \\
$\square$ & TPA\# \\
\hline
\end{tabular}

DELIVERABLE:

Report

Letter

Drawings

Other (specify)
ADDRESS TO:

$\square$ DOE-HQ

DOE-RL

$\square$ Other (specify)

Milestone Description:

A quarterly audit status report and quarterly corrective action tracking report (DARTS) are due to the customer approximately 10 working days after the end of each quarter of the fiscal year.

Description of what constitutes completion of this milestone:

Submittal of each report on the due date established by RL.

\begin{tabular}{|ll|ll}
\hline Cost Account Manager & Date & Program/Project Manager & Date \\
\hline Program Element Manager & Date & DOE Monitor & Date
\end{tabular}


FINANCIAL SERVICES

WBS 6.10 .4

\section{Westinghouse Hanford Company MILESTONE DESCRIPTION SHEET}

Title: Corrective Action Follow-up

Date: $08 / 31 / 94$

Assigned To: Financial Review and Audits

CIN:

Program WBS Designator: $6 \cdot 10.4 .3$

Due Date: end of each fiscal gtr

Control Number: FFS-95-055 through FFS-95-058

MILESTONE TYPE:

$\square$ DOE-HQ

DOE-RL

CNTR

\begin{tabular}{ll}
$\square$ & State \\
$\square$ & Federal \\
$\square$ & DOE \\
$\square$ & RCRA \\
$\square$ & TPA\# \\
\hline
\end{tabular}

DIVISION:

Revision:

DELIVERABLE:
$\square$ Report
$\square$ Letter
$\square$ Drawings
Other (specify)

Documented follow-up
ADDRESS TO:

$\square$ DOE-HQ

$\square$ DOE-RL

Other (specify)

WHC Audit Mgr

\section{Documented follow-up}

\section{Milestone Description:}

Initiate and complete audit finding corrective action follow-up process each quarter.

\section{Description of what constitutes completion of this milestone:}

Documented follow-up by the end of each quarter of all audit findings with completion due dates falling in the quarter.

\begin{tabular}{|ll|ll|}
\hline Cost Account Manager & Date & Program/Project Manager & Date \\
\hline Program Element Manager & Date & DOE Monitor & Date \\
\hline
\end{tabular}




\section{B WBS Milestone Description Sheet}

FINANCIAL SERVICES

WBS 6.10 .4

\section{Westinghouse Hanford Company MILESTONE DESCRIPTION SHEET}

\begin{tabular}{|c|c|c|c|}
\hline \multicolumn{3}{|c|}{ Title: Annual Allowable Cost Audit } & Date: $08 / 31 / 94$ \\
\hline \multicolumn{3}{|c|}{ Assigned To: Financial Review and Audits } & CIN: \\
\hline \multicolumn{3}{|c|}{ Program WBS Designator: 6.10 .4 .3} & Due Date: $12 / 31 / 94$ \\
\hline \multicolumn{3}{|c|}{ Control Number: FFS-95-059 } & Revision: \\
\hline $\begin{array}{l}\text { MILESTONE TYPE: } \\
\square \text { DOE-HQ } \\
\text { DOE-RL } \\
\square \text { CNTR }\end{array}$ & $\begin{array}{ll} & \text { DIVISION: } \\
\square & \text { State } \\
\square & \text { Federa } \\
\square & \text { DOE } \\
\square & \text { RCRA } \\
\square & \text { TPA\# } \\
\end{array}$ & $\begin{array}{ll} & \text { DELIVERABLE: } \\
\square & \text { Report } \\
\square & \text { Letter } \\
\square & \text { Drawings } \\
\text { Other (specify) } \\
\text { Audit }\end{array}$ & $\begin{array}{ll} & \text { ADDRESS TO: } \\
\square & \text { DOE-HQ } \\
\text { DOE-RL } \\
\square \text { Other (specify) }\end{array}$ \\
\hline
\end{tabular}

Annual Fiscal Year End Audit covering detailed testing to provide reasonable assurance that WHC internal controls are sufficient to prevent unallowable costs from being charged to the D.OE contract.

\section{Description of what constitutes completion of this milestone:}

Completion of the audit testing in the year end audit related to allowable costs by December 31, 1994.

\begin{tabular}{|ll|ll|}
\hline Cost Account Manager & Date & Program/Project Manager & Date \\
\hline Program Element Manager & Date & DOE Monitor & Date \\
\hline
\end{tabular}


3.B. WBS Milestone Description Sheet
Westinghouse Hanford Company

Finance and Administration

WBS 6.10

FINANCIAL SERVICES

WBS 6.10 .4

\section{Westinghouse Hanford Company \\ MILESTONE DESCRIPTION SHEET}

Title: Electronic Auditing

Date: $08 / 31 / 94$

Assigned To: Financial Review and Audits

CIN:

Program WBS Designator: 6.10 .4 .3

Due Date: $12 / 31 / 94$

Control Number: FFS-95-060

MILESTONE TYPE:

$\square$ DOE-HQ

$\square$ DOE-RL

CNTR

\begin{tabular}{|ll} 
& \multicolumn{1}{c|}{ DIVISION: } \\
$\square$ & State \\
$\square$ & Federa] \\
$\square$ & DOE \\
$\square$ & RCRA \\
$\square$ & TPA\# \\
\hline
\end{tabular}

Revision:

DELIVERABLE:

$\square$ Report

$\square$ Letter

$\square$ Drawings

- Other (specify)

Documented follow-up
ADDRESS TO:

$\square$ DOE-HQ

$\square$ DOE-RL

Other (specify)

WHC Audit Mgr

Milestone Description:

Initiate and complete a study of electronic audit process software packages in conjunction with Westinghouse ETectric Corporate Audit.

Description of what constitutes completion of this milestone:

A. Complete evaluation and rank critical aspects of the following software packages by $12 / 31 / 94$ :
1. Price Waterhouse - Teamate
2. Price Waterhouse - APEX
3. Deloitte - AT
4. Bankers Trust - Lotus notes application

B. Make recommendation to WEC Systems Technology Advisory Group.

\begin{tabular}{|ll|ll|}
\hline Cost Account Manager & Date & Program/Project Manager & Date \\
\hline Program Element Manager & Date & DOE Monitor & Date . \\
\hline
\end{tabular}


3.B WBS Milestone

Description Sheet
Westinghouse Hanford Company

Finance and Administration

WBS 6.10

FY 1995 SSPP

FINANCIAL SERVICES

HBS 6.10 .4

\section{Westinghouse Hanford Company \\ MILESTONE DESCRIPTION SHEET}

Tit7e: Annual Inspector General Summary Report

Date: $08 / 31 / 94$

Assigned To: Financial Review and Audits

CIN :

Program WBS Designator: 6 10.4.3

Due Date: $1 / 15 / 95$

Control Number: FFS-95-061

MILESTONE TYPE:

$\square$ DOE-HQ

DOE-RL

$\square$ CNTR

\begin{tabular}{|ll|} 
& DIVISION: \\
$\square$ & State \\
$\square$ & Federa1 \\
$\square$ & DOE \\
$\square$ & RCRA \\
$\square$ & TPA\# \\
\hline & \\
\hline
\end{tabular}

Revision:

DELIVERABLE:

Report

Letter

Drawings

other (specify)
ADDRESS TO:

$\square$ DOE-HQ

$\square$ DOE-RL

Other (specify)

DOE-IG

\section{Milestone Description:}

Annual report is a summary of all audits completed in the fiscal period. The report highlights significant audit findings and details the allowable cost audit approach and any unallowable costs detected throughout the year.

Description of what constitutes completion of this milestone:

Issuance of the Annual Report on January 15, 1995.

\begin{tabular}{|ll|ll|}
\hline Cost Account Manager & Date & Program/Project Manager & Date \\
\hline Program Element Manager & Date & DOE Monitor & Date \\
\hline
\end{tabular}




\section{B WBS Milestone Description Sheet}

Westinghouse Hanford Company

Finance and Administration

WBS 6.10

FY 1995 SSPP

FINANCIAL SERVICES

WBS 6.10 .4

\section{Westinghouse Hanford Company}

MILESTONE DESCRIPTION SHEET

\begin{tabular}{|c|c|c|c|}
\hline \multicolumn{3}{|c|}{ Title: Electronic Audit Analysis Software } & Date: $08 / 31 / 94$ \\
\hline \multicolumn{3}{|c|}{ Assigned To: Financial Review and Audits } & CIN: \\
\hline \multicolumn{3}{|c|}{ Program WBS Designator: 6.10 .4 .3} & Due Date: $3 / 31 / 95$ \\
\hline \multicolumn{3}{|c|}{ Control Number: FFS-95-062 } & Revision: \\
\hline $\begin{array}{l}\text { MILESTONE TYPE: } \\
\square \text { DOE-HQ } \\
\square \text { DOE-RL } \\
\text { CNTR }\end{array}$ & $\begin{array}{ll} & \text { DIVISION: } \\
\square & \text { State } \\
\square & \text { Federal } \\
\square & \text { DOE } \\
\square & \text { RCRA } \\
\square & \text { TPA\# } \\
\end{array}$ & $\begin{array}{l}\quad \text { DELIVERABLE: } \\
\square \text { Report } \\
\square \text { Letter } \\
\square \text { Drawings } \\
\text { Other (specify) } \\
\text { Documented follow-up }\end{array}$ & $\begin{array}{l}\text { ADDRESS TO: } \\
\square \text { DOE-HQ } \\
\text { DOE-RL } \\
\text { Other (specify) } \\
\text { WHC Audit Mgr }\end{array}$ \\
\hline \multicolumn{4}{|l|}{ Milestone Description: } \\
\hline \multicolumn{4}{|c|}{ Market survey of the current Audit Analysis software packages. } \\
\hline \multicolumn{4}{|c|}{ Description of what constitutes completion of this milestone: } \\
\hline \multicolumn{4}{|c|}{$\begin{array}{l}\text { 1. Document purported benefits of available Audit Analysis software and evaluate } \\
\text { cost/benefit to WHC. } \\
\text { 2. Make implementation recommendations on the software packages reviewed. }\end{array}$} \\
\hline \multicolumn{2}{|l|}{ Cost Account Manager } & \multicolumn{2}{|c|}{ Program/Project Manager Date } \\
\hline \multicolumn{2}{|c|}{ Program E7ement Manager Date } & \multicolumn{2}{|c|}{ DOE Monitor Date } \\
\hline
\end{tabular}




\section{B HBS Milestone Description Sheet}

Hestinghouse Hanford Company

Finance and Administration

WBS 6.10

FINANCIAL SERVICES

WBS 6.10 .4

\section{Westinghouse Hanford Company MILESTONE DESCRIPTION SHEET}

\begin{tabular}{|c|c|c|c|}
\hline \multicolumn{3}{|c|}{ Title: Fiscal Year 1996 Audit Call Letter } & Date: $08 / 31 / 94$ \\
\hline \multicolumn{3}{|c|}{ Assigned To: Financial Review and Audits } & CIN: \\
\hline \multicolumn{3}{|c|}{ Program WBS Designator: $6.10 \cdot 4.3$} & Due Date: $5 / 10 / 95$ \\
\hline \multicolumn{3}{|c|}{ Control Number: FFS-95-063 } & Revision: \\
\hline $\begin{array}{l}\text { MILESTONE TYPE: } \\
\square \text { DOE-HQ } \\
\square \text { DOE-RL } \\
\square \text { CNTR }\end{array}$ & \begin{tabular}{ll} 
& \multicolumn{1}{c}{ DIVISION: } \\
$\square$ & State \\
$\square$ & Federal \\
$\square$ & DOE \\
$\square$ & RCRA \\
$\square$ & TPA\# \\
\end{tabular} & $\begin{array}{ll} & \text { DELIVERABLE: } \\
\square & \text { Report } \\
\text { Letter } \\
\square \text { Drawings } \\
\square \text { Other (specify) }\end{array}$ & 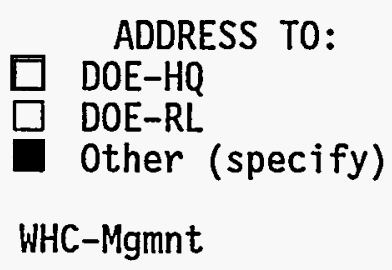 \\
\hline
\end{tabular}

Milestone Description:

The annual call letter requests input from management on areas they believe would benefit from an audit. Management also provides a risk ranking for each suggested audit.

Description of what constitutes completion of this milestone:

Issuing an audit call letter to WHC management soliciting their input to the FY 1996 audit planning process by May 10, 1995.

\begin{tabular}{|ll|ll|}
\hline Cost Account Manager & Date & Program/Project Manager & Date \\
\hline Program Element Manager & Date & DOE Monitor & Date \\
\hline
\end{tabular}


FINANCIAL SERVICES

HBS 6.10 .4

\section{Westinghouse Hanford Company MILESTONE DESCRIPTION SHEET}

\begin{tabular}{|c|c|c|c|}
\hline \multicolumn{3}{|c|}{ Title: FY 1996 Audit Plan } & Date: $08 / 31 / 94$ \\
\hline \multicolumn{3}{|c|}{ Assigned To: Financial Review and Audits } & CIN: \\
\hline \multicolumn{3}{|c|}{ Program WBS Designator: 6.10 .4 .3} & Due Date: $7 / 1 / 95$ \\
\hline \multicolumn{3}{|c|}{ Control Number: FFS-95-064 } & Revision: \\
\hline $\begin{array}{l}\text { MILESTONE TYPE: } \\
\text { DOE-HQ } \\
\text { DOE-RL } \\
\square \text { CNTR }\end{array}$ & 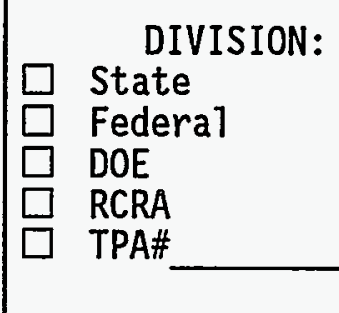 & $\begin{array}{ll} & \text { DELIVERABLE: } \\
\square & \text { Report } \\
\square & \text { Letter } \\
\square & \text { Drawings } \\
\text { Other (specify) } & \text { Otan } \\
\text { Plan }\end{array}$ & $\begin{array}{l}\text { ADDRESS TO: } \\
\square \text { DOE-HQ } \\
\text { DOE-RL } \\
\text { Other (specify) } \\
\text { DOE-IG }\end{array}$ \\
\hline
\end{tabular}

Milestone Description:

Detailed audit plan for FY 1996 containing all assumptions, risk ranking factors, and planned audits for FY 1996.

Description of what constitutes completion of this milestone:

Issuance of the plan to RL and the DOE-IG on July 1, 1995.

\begin{tabular}{|ll|ll|}
\hline Cost Account Manager & Date & Program/Project Manager & Date \\
\hline Program Element Manager & Date & DOE Monitor & Date \\
\hline
\end{tabular}

